\title{
Sovereigns, Upstream Capital Flows and Global Imbalances
}

\section{Citation}

Alfaro, Laura, Sebnem Kalemli-Ozcan, and Vadym Volosovych. "Sovereigns, Upstream Capital Flows and Global Imbalances." Journal of the European Economic Association 12, no. 5 lOctober 2014): 1240-1284.

\section{Published Version}

http://onlinelibrary.wiley.com/doi/10.1111/jeea.12106/abstract

\section{Permanent link}

http://nrs.harvard.edu/urn-3:HUL.InstRepos:16422847

\section{Terms of Use}

This article was downloaded from Harvard University's DASH repository, and is made available under the terms and conditions applicable to Open Access Policy Articles, as set forth at http:// nrs.harvard.edu/urn-3:HUL.InstRepos:dash.current.terms-of-use\#OAP

\section{Share Your Story}

The Harvard community has made this article openly available.

Please share how this access benefits you. Submit a story.

Accessibility 


\title{
Sovereigns, Upstream Capital Flows, and Global Imbalances
}

\author{
Laura Alfaro \\ Harvard Business School and NBER \\ Sebnem Kalemli-Ozcan \\ University of Maryland, CEPR and \\ NBER \\ Vadym Volosovych \\ Erasmus University Rotterdam, \\ Tinbergen Institute and ERIM
}

March 2014

\begin{abstract}
We construct measures of net private and public capital flows for a large cross-section of developing countries considering both creditor and debtor side of the international debt transactions. Using these measures, we demonstrate that sovereign-to-sovereign transactions account for upstream capital flows and global imbalances. Specifically, we find i) international net private capital flows (inflows minus outflows of private capital) are positively correlated with countries' productivity growth, ii) net sovereign debt flows (government borrowing minus reserves) are negatively correlated with growth only if net public debt is financed by another sovereign, iii) net public debt financed by private creditors is positively correlated with growth, iv) public savings are strongly positively correlated with growth, whereas correlation between private savings and growth is flat and statistically insignificant. These empirical facts contradict the conventional wisdom and constitute a challenge for the existing theories on upstream capital flows and global imbalances. (JEL: F21, F41, O1)

Keywords: current account, aid/government debt, reserves, productivity.
\end{abstract}

Acknowledgments: We thank our referees, editor Fabrizio Zilibotti, Pierre-Olivier Gourinchas and participants at the 2010 AEA meetings, 2010 NBER-IFM meeting, the 2010 SEA meetings, 2012, ECB Globalization Conference, 2012 CREI-UPF Summer Workshop and the seminars at Erasmus University Rotterdam, De Nederlandsche Bank for comments, and Francesco Caselli, Gian Maria Milesi-Ferretti, Elias Papaioannou and Frank Warnock for insightful discussions.

E-mail: lalfaro@hbs.edu (Alfaro); kalemli@econ.umd.edu (Kalemli-Ozcan); volosovych@ese.eur.nl (Volosovych) 


\section{Introduction}

Uphill capital flows and global imbalances have taken center stage at academic and policy debates for some time. Over the past two decades, capital seems to have been flowing upstream from fast-growing to stagnant countries. At the same time, emerging market economies experiencing rapid growth have accumulated vast foreign reserves. Many of the theoretical explanations advanced for these phenomena center on these countries' relatively higher saving rates. ${ }^{1}$

Unfortunately, the empirical literature is thin. Correlations using the current account balance with a reversed sign - that is, the difference between a nation's investment and its savings - as a proxy for net capital flows and productivity growth motivate the existing theoretical literature. ${ }^{2}$ However, we show that such correlations can have different signs and thus imply opposite relationships between net capital flows and growth depending on which countries dominate the sample. This is because net capital flows consist of net private flows and net public flows and the correlations of these two types of net flows with productivity growth differ in sign. Depending on whether the private or public flows dominate the total flows in terms of magnitude in different samples, one can find a positive or a negative correlation between net capital flows and productivity growth.

To demonstrate this, we have carefully constructed measures of private and public net capital flows for a large cross-section of developing countries, considering both the creditor and the debtor sides of international transactions. Net private capital flows include net inflows of foreign direct investment (FDI), portfolio equity investment, and private debt. For private debt we consider both private sector's borrowing on net and also debt investment by foreign private investors. Net public capital flows include, among other things, grants, concessional aid, or any government-guaranteed debt, where reserves is netted out from all. Using these measures, we find (a) that a country's net international private capital flows (inflows minus outflows of private capital) are positively correlated with its productivity growth and (b) that a country's sovereign net debt flows (government borrowing minus accumulation of foreign reserves) are negatively correlated with its growth only if the government debt is financed by another sovereign.

Upstream capital flows seem puzzling from the perspective of neoclassical theory since this theory predicts that growing countries should receive capital flows on net and therefore there should be a positive correlation between net capital flows and productivity growth. We show that sovereign-to-sovereign transactions can account

1. For recent work studying these phenomena, see Caballero, Farhi, and Gourinchas (2008), Aguiar and Amador (2011), Benigno and Fornaro (2012), Gourinchas and Jeanne (2013), Mendoza, Quadrini, and Rios-Rull (2009), and Song, Storesletten, and Zilibotti (2011), among others.

2. Throughout this paper, net capital flows are defined as inflows minus outflows, that is, net changes of foreign liabilities minus assets. See Section 2 for detailed definitions of data. 
for the observed upstream capital flows and global imbalances at the same time. ${ }^{3} \mathrm{Net}$ private flows go to growing countries, even if these countries are net exporters of total capital. Such countries send capital out on net in terms of sovereign-to-sovereign transactions. For example, when we look at the lender side of government borrowing, we find a positive correlation between government borrowing from the private sector and the country's growth. However, if the borrowing by government is from another government - a transaction that we call a sovereign-to-sovereign flow-then it is negatively correlated with growth. Since the simplest textbook neoclassical model does not involve a government sector we interpret these results, i.e, private sector's borrowing on net in growing countries and public sector's borrowing from private creditors on net also in growing countries, as being consistent with the neoclassical model. The challenge is then to model the government sector's puzzling behavior. ${ }^{4}$

The daunting task of calculating private and public capital flows requires data from both the creditor and the debtor sides. Public flows should include all forms of government. Aid flows, for example, include concessional lending as well as grants and do not (by design or in practice) finance lump-sum transfers. The most direct and straightforward measure of private flows is the sum of net FDI, equity, and that part of the debt that can be considered—with a high degree of confidence-private. ${ }^{5}$ The main difficulty involves decomposing total debt into private and public components because the International Monetary Fund's (IMF) Balance of Payments statistics, the traditional source of such data, do not fully identify private and public issuers and holders of debt securities. We perform such a decomposition using data from the World Bank's Global Development Finance database. There is no a priori reason to focus on developing countries as opposed to the whole world other than the fact that decomposing net debt flows into private and public components can only be done for countries classified as developing. This is because these countries are required by the World Bank to report the amounts and types of foreign debt, including the creditor side, in order to be eligible for international borrowing.

An alternative measure of private capital flows is to calculate them as a "residual"; that is, subtracting all public flows from a measure of total capital flows (such as the negative of the current account balance). Here, the way we measure public flows directly affects the measurement of private flows. If all sovereign-to-sovereign flows are not subtracted from the current account balance, the resulting measure of private capital flows will still be "contaminated" by public flows and will give misleading

3. By sovereign, we mean multilateral, bilateral, government, and government-like institutions and agencies. These would include, among others, international financial institutions, bilateral government flows, all forms of government (including, federal or central, state, and municipal), public enterprises, central banks, sovereign wealth funds and related intermediaries, and publicly guaranteed activities. We use the terms "sovereign," "public," "government," and "official" interchangeably.

4. The flip side of this is private capital going out and public capital coming in, in the form of aid, when we consider stagnant countries.

5. See Section 2 for an in-depth discussion of measurement issues in our data and decomposition methods. 
results in terms of the international allocation of private capital if the public and private flows behave differently — as we find they do. When we calculate the residual private flows by subtracting our preferred measure of sovereign-to-sovereign flows from the negative of the current account balance, we obtain the same results as found by using direct measures of private capital flows.

Two key facts explain our findings. First, over the past 40 years, capital flows into low-productivity developing countries have largely taken the form of official aid/debt (concessional flows from bilateral and multilateral donor institutions). ${ }^{6}$ When aid flows are subtracted from total flows, there is total capital flight out of these countries. Second, net capital outflows from high-productivity emerging markets - a more recent phenomenon of upstream capital flows - have been, on average, in the form of official reserves accumulation. These two facts explain why using current account and using the components of financial account data yield different results.

We find that, over the past three decades, although the developed world received, on net, more foreign capital than emerging markets did - a phenomenon known as the Lucas paradox-emerging markets with above-world-average growth do not generally run current account surpluses. ${ }^{7}$ Eastern European countries, for example, had aboveaverage growth and ran current account deficits in recent decades. During our sample period, only five Asian countries-China, Korea, Malaysia, Singapore, and Hong Kong-had current account surpluses of the same order of magnitude as that of Luxembourg. ${ }^{8}$ Although this handful of emerging Asian countries saw net total capital flow upstream to capital-rich advanced economies, none, on average, exported private capital. These countries are net borrowers in terms of FDI, portfolio equity, and private debt and they are not representative of the broad sample of developing countries; a number of Eastern European and Central Asian countries, Albania, Azerbaijan, Moldova, Turkey, for example, were net borrowers both in private and public capital, as were other countries in Asia and the most in Latin America.

We find a robust negative correlation between total net capital flows and growth, as others have done in the literature using smaller samples mostly dominated by Asian and African countries (e.g., Aguiar and Amador, 2011; and Gourinchas and Jeanne, 2013). In larger samples of developing countries, the correlation between net capital flows and productivity is weakly positive (e.g., Prasad, Rajan, and Subramanian, 2006)..$^{9}$ In this sense, our results are consistent with those of Reinhart and Tashiro

\footnotetext{
6. From the 1930s shutdown of the international markets up to the mid-1970s, debt flows to most developing countries were generally restricted to international organizations/government loans (sovereignto-sovereign flows). Following the 1982 debt crisis, official creditors once again dominated lending to many developing countries and in particular low income countries. See Henry and Lorentzen (2003) and Obstfeld and Taylor (2004).

7. Alfaro, Kalemli-Ozcan, and Volosovych (2008) show that the Lucas paradox is largely explained by the high institutional quality in developed countries.

8. Thailand and Indonesia were also net capital exporters for 1990-2007 and 2000-2007, respectively.

9. Our results using a large sample of a cross-section of developing countries are also consistent with earlier large-sample work which documented weakly positive or insignificant correlations between current account and growth. See, for example, Chin and Prasad (2003) and references therein.
} 
(2013), who show that Asian central banks are the ones buying reserves in developed countries and hence are responsible for the capital outflow. Krishnamurty and VissingJorgensen (2012) similarly show that foreign central banks, especially those in Asia, hold a lot of the treasuries and have been increasing their holdings. ${ }^{10}$ In addition, there is a broad literature stressing that aid flows have political economy motivations that account for their negative correlation with growth (Alesina and Dollar, 2000; Arslanalp and Henry, 2005; Kuziemko and Werker, 2006).

We interpret our results as follows. The neoclassical growth model relies on a representative consumer. In essence, there is no government, or at least no government that does anything different from what the atomistic agent or the social planner would do. But if the government and private agents do behave differently, as we show, then we need different models to explain the behavior of the private sector and the behavior of the government. For example, one could take the behavior of the government as given (that is, the government is accumulating reserves for some un-modeled reason) and then ask if the observed behavior of the private sector is consistent with the predictions of the neoclassical model. If, in the presence of high growth, the private sector is saving a lot, then there would be a private saving "puzzle." But if the private sector is running a current account deficit, as we clearly show in this paper, then one could say that the private sector conforms to the neoclassical theory and that the only theoretical problem is to understand the behavior of the government which had been taken as a given. In fact, our results confirm this very conjecture. Using domestic savings data rather than international capital flows data, we find that the correlation of public savings with growth is strongly positive while the correlation of private savings with growth is statistically insignificant. We argue that, given the stark difference in the behavior of private and public net capital flows, one cannot interpret results based on total net capital flows and growth correlations as evidence for or against the simplest neoclassical model. ${ }^{11}$

Our exercise sheds light on theory. Although many of the theoretical mechanisms proposed to explain uphill capital flows and global imbalances have substance, it is important to ask how they fit together. The most common theoretical references that explain uphill flows and global imbalances are models in which domestic financial frictions and/or precautionary motives lead to over-saving in emerging markets. The

10. The Treasury International Capital (TIC) data underestimates central banks' holdings of the U.S. government securities since they also hold them via sovereign wealth funds and other intermediaries. Our results are also consistent with recent work that proposes the importance of investigating gross flows; see Forbes and Warnock (2012) and Lane and Milesi-Ferretti (2007), among others.

11. In the simplest Ricardian neoclassical model, with dissipative government consumption and no government investment, the savings and investment behavior of the private sector is what drives capital flows. Ricardian equivalence relating private and public saving decisions requires conditions of lumpsum taxes, perfect capital markets, infinite horizons, and certainty about future levels of income. Apart from notable income uncertainty and capital market imperfections, developing countries have particularly distortionary tax systems and sizeable informal sectors. For a systematic study that shows the failure of Ricardian equivalence in a cross-section of countries, see Loayza, Schmidt-Hebbel, and Serven (2000) and for evidence on its failure in the U.S., see Krishnamurty and Vissing-Jorgensen (2012). See also Obstfeld and Rogoff (1995) for further discussion on the lack of evidence of Ricardian equivalence. 
main focus has been on private capital outflows as the key driver of the positive correlation between growth and the current account. Our findings, however, document the direction of capital flows to be much more nuanced than is commonly appreciated. We find that (a) on average, private debt as well as FDI and portfolio equity flow on net to high-growth countries, (b) emerging markets' public borrowing from private lenders is also positively correlated with their growth, and (c) the negative correlation between growth and foreign-assets accumulation is driven by transactions between sovereigns. Thus, any theoretical explanation of uphill flows and global imbalances must take into account that current account net of sovereign-to-sovereign flows is negatively correlated with growth; that is private capital flows downhill. ${ }^{12}$

The rest of the paper is organized as follows. Section 2 describes the data and methodology. Section 3 presents descriptive patterns. Section 4 discusses the regressions analysis. Section 5 reconciles our results with those in the literature. Section 6 reviews the related theoretical literature and discusses the implications of our findings for existing theories. Section 7 concludes.

\section{Data and Methodology}

Our objective in this paper is to search for broad patterns on the international allocation of capital and provide explanations that characterize an average developing country. This task is daunting because developing countries are characterized by government interventions, capital controls, sovereign risk, reliance on foreign aid, high volatility, as well as the data quality issues.

A country's Balance of Payments (BOP) is the set of accounts that measures all the economic transactions between the country and the rest of the world. The main accounts are the current account and the financial account with the sum of the balances on the two accounts equal zero. ${ }^{13}$ The current account (CA) balance is the sum of country's exports minus imports in goods and services, net factor income, and transfers payments. Alternatively, the CA can be represented as the country's domestic private and government savings less its private and government investment. The financial account (FA) records the net acquisition of financial assets and the net incurrence of liabilities.

In BOP accounting, a transaction resulting in a payment to a foreign entity is entered as a debit (given a negative "-" sign) while a transaction resulting in a receipt

12. See for example Aguiar and Amador (2011) and Benigno and Fornaro (2012). The work by Favilukis, Ludvigson, and Van Nieuwerburgh (2012) models the uphill flows into the U.S. solely as sovereign-tosovereign flows and studies the welfare implications of such flows.

13. To be precise, the 5th edition of the Balance of Payments Manual (BPM) published by the IMF defines the Balance of Payments as a statistical statement that summarizes transactions between residents and nonresidents during a period. It consists of the current account, the financial account, the capital account, and the errors and omissions (balancing account). The BOP uses double entry bookkeeping standards by which the sum of all accounts equals zero (current account + financial account + capital account + errors and omissions $=0$ ). 
from foreigners is entered as a credit (given a positive "+" sign). ${ }^{14}$ When a country borrows from abroad, for example, by selling an asset (a promise to repay in the future or IOU), the transaction enters the financial account with a positive sign, resulting in an increase of the country's foreign liability position or a capital inflow into the country. When a country lends abroad, its resident purchases a foreign asset or claim against the foreign country. In this case, the financial account is debited because a payment is made to foreigners, resulting in an increase of foreign asset position or a capital outflow.

Broadly then, a country with a FA deficit (or a CA surplus) is a net lender, sending its surplus net savings to the rest of the world, thereby increasing its net holdings of foreign assets or reducing its net liabilities. Conversely, a country with a FA surplus (or a CA deficit) is a net borrower from the rest of the world, attracting surplus savings from overseas, thereby increasing net liabilities or reducing net assets abroad.

\subsection{Decomposing Net Capital Flows}

\section{Capital Flows}

The International Financial Statistics (IFS) database issued by the IMF is the standard data source for annual capital flows (acquisitions and disposals of financial assets and liabilities) recorded in the financial account of BOP. The main categories include direct investment (usually called foreign direct investment, FDI), portfolio equity investment, and a variety of debt flows. ${ }^{15}$ Portfolio debt inflows include investments in bonds, debentures, notes, money market, or negotiable debt instruments. Other investment category includes debt-like instruments such as loans, transactions in currency and deposits, financial leases, and trade credits. Transactions with financial derivatives are reported as a separate line.

Following closely Lane and Milesi-Ferretti (2001), we use the flows recorded in the financial account of the BOP and decompose the CA balance into public and

14. Exports are credit items, for example, while imports are debits. The purchases of financial assets are entered as a debit in the financial account, and sales of assets are credits. While this paper was written a new 6th edition of the BPM was released, and from August 2012 the IMF began publishing the country international statistics data based on a substantially changed BPM6 presentation. Among other things, the BPM6 introduced a new "sign convention" for the BOP entries by which the items of the financial account have been changed from credits and debits (with corresponding "+" and "-" sign) to "net acquisition of financial assets" and "net incurrence of liabilities." As the result, all changes due to credit and debit entries are recorded on a net basis separately for financial assets and liabilities, and a positive sign indicates an increase in assets or liabilities, and a negative sign indicates a decrease in assets or liabilities. In other words, the name of the item, not the sign, is the guide on the direction of the money flow according to the BPM6. Because the data coverage under the BPM6 convention starts only in 2005, in the rest of this paper we follow the more familiar BPM5 convention. We update the data time series with more recent data reported under the new BPM6 convention but continue following the "sign convention" of BPM5.

15. The IMF classifies an investment as direct if a foreign investor holds at least 10 percent of a local firm's equity while the remaining equity purchases are classified under portfolio equity investment. 
private flows, which are of particular interest for this paper, as follows:

$$
\begin{aligned}
C A & =(\Delta F D I A+\triangle E Q A+\triangle P \operatorname{riv} D A-\Delta F D I L-\triangle E Q L-\triangle \operatorname{Priv} D L+E O) \\
& +(\Delta R E S+\triangle P u b D A-\triangle P u b D L-I M F-E F)
\end{aligned}
$$

or in short,

$$
\begin{aligned}
C A & =\text { (Flows of Private Assets }- \text { Flows of Private Liabilities }) \\
& + \text { (Flows of Public Assets }- \text { Flows of Public Liabilities }) .
\end{aligned}
$$

In (1), the $\triangle$ FDIA and $\triangle$ FDIL denote, respectively, flows of FDI abroad (assets) and into the economy (liabilities), $\triangle \mathrm{EQA}$ and $\triangle \mathrm{EQL}$ are flows of portfolio equity assets and liabilities, $\triangle$ PrivDA and $\triangle$ PrivDL denote flows of private debt (portfolio debt, loans, and other instruments including financial derivatives, currency and deposits, financial leases, and trade credits), and EO is net errors and omissions. ${ }^{16}$ $\triangle$ RES denotes changes in reserve assets controlled by the country authorities, $\triangle$ PubDA and $\triangle$ PubDL are flows of public debt assets and liabilities, IMF is the IMF credit, and EF is exceptional financing. ${ }^{17}$ We use net flows in our analysis (flows recorded as liabilities minus assets). Thus the negative net flows means that capital is flowing out on net and positive means capital is flowing in on net. The decomposition (2) is obtained by adding up the corresponding net flows of private and public assets and liabilities. Similarly to Lane and Milesi-Ferretti (2001), we treat net errors and omissions as unrecorded capital outflows and add them as a part of private debt assets.

The decomposition (2) implies that we can calculate net private flows in two ways:

1. Use the direct estimate of net private flows from the first line of (1) or (2), assuming one can decompose debt into private and public components relatively accurately.

2. Calculate net private flows as a residual by subtracting public debt flows from the negative of the current account.

Both of these approaches require us to calculate sovereign-to-to sovereign net debt flows. We will follow both approaches.

16. Notice that we change Lane and Milesi-Ferretti's (2001) decomposition for our purposes. We present it in terms of flows concepts as reported in BOP statistics, whereas they present the decomposition of the $\mathrm{CA}$ in terms of the components of International Investment Position (IIP) accounts which reports stocks of foreign assets and liabilities.

17. The Balance of Payments statistics includes, in addition to the financial account, the capital account which consists of acquisition or disposal of non-produced, intangible assets (e.g., patents, copyrights, trademarks, franchises, etc.) and capital transfers between residents and non-residents. The capital account is negligible for most countries. For the period 1980-2007 the mean as a percentage of GDP is 0.5 , with much smaller median 0.15 , min -1.5 , and max 6.3 (the latter corresponds to Tanzania and Yemen). For the purposes of this paper, we could try to record debt forgiveness and investment grants (both a part of capital transfers) as sovereign-to-sovereign flows. However, the level of detail in the BOP statistics does not allow to distinguish these parts from the overall capital transfers. Therefore, we exclude the flows in the capital account from the main analysis. As the result, they are "assigned" to the private flows in our residual measures (computed as the total-public flows); or under-recorded in our direct measures of private flows. 


\section{Data Issues}

To date, the IFS database is the most comprehensive and comparable source of the BOP statistics for many countries. Nevertheless, there are several issues behind the compilation of the BOP statistics, as discussed in greater detail by Lane and Milesi-Ferretti (2001) and Alfaro, Kalemli-Ozcan and Volosovych (2007). There are substantial country differences in terms of time coverage, missing, unreported, or misreported data, in particular for developing countries. Some countries do not report data for all forms of capital flows. Outflows data tend to be misreported in most countries and, as the result, captured in the "errors and omissions" item. ${ }^{18}$ Unfortunately, it is hard to verify whether the data are really missing as opposed to simply being zero. ${ }^{19}$ Due to the debt crisis of the 1980 s there are several measurement problems related to different methodologies of recording non-payments, rescheduling, debt forgiveness and reductions. ${ }^{20}$

Decomposing the total flows into private and public components is crucial for our analysis. We argue, as in Alfaro, Kalemli-Ozcan, and Volosovych (2008), that FDI and portfolio equity flows can be assigned to private-to-private transactions. The difficulty lies in assigning a variety of debt components. The IFS database covers both private and public issuers and holders of debt securities. However, it is difficult to divide the available data by private-public creditor and debtor. Although the IFS reports the transactions by monetary authorities, general government, banks and other sectors, this information is not available for most countries for long periods of time.

The World Bank's (WB) Global Development Finance (GDF) database, which focuses on the liability (debtors) side as the source of the data, provides the detailed debt decomposition into official and private borrowers and some information on the identity of creditors. Figure 1, taken from the GDF Manual, shows the main debt components available in the database. Notice that, Total External Debt $=$ Short-Term Debt + Use of IMF credits + Long-Term Debt and Long-Term Debt $=$ Public and Publicly Guaranteed (PPG) Debt + Private Non-Guaranteed Debt.

Using the GDF data, we make an effort to supplement the data missing in BOP statistics and decompose net (total) debt into public and private debt flows by assigning the components shown in Figure 1 to the appropriate debt category. For example, we can confidently argue that the Use of IMF credits is the sovereign-to-sovereign transaction but the creditor in total PPG debt could be either the private entity or the sovereign. As seen in Figure, the GDF gives quite a lot of detail regarding the public

18. Frankel (2001), for example, argues that data collection is much better for capital flowing in a country than capital flowing out. The author gives the example that no comprehensive survey of the U.S. residents holdings of foreign securities had been conducted since World War II, until one was conducted in 1994.

19. Several developing countries tend to report data for liabilities only and no data for assets. This is especially the case for foreign direct investment flows. Some of these data, reported in the liability line, seem to correspond to net flows, i.e., liabilities minus assets. However, it is difficult to verify whether this is the case as opposed to the asset data simply being non-available. For example, portfolio equity data for most developing countries were negligible until recently.

20. As noted by Lane and Milessi-Feretti (2001) these issues create large discrepancies between debt data reported by different agencies. 


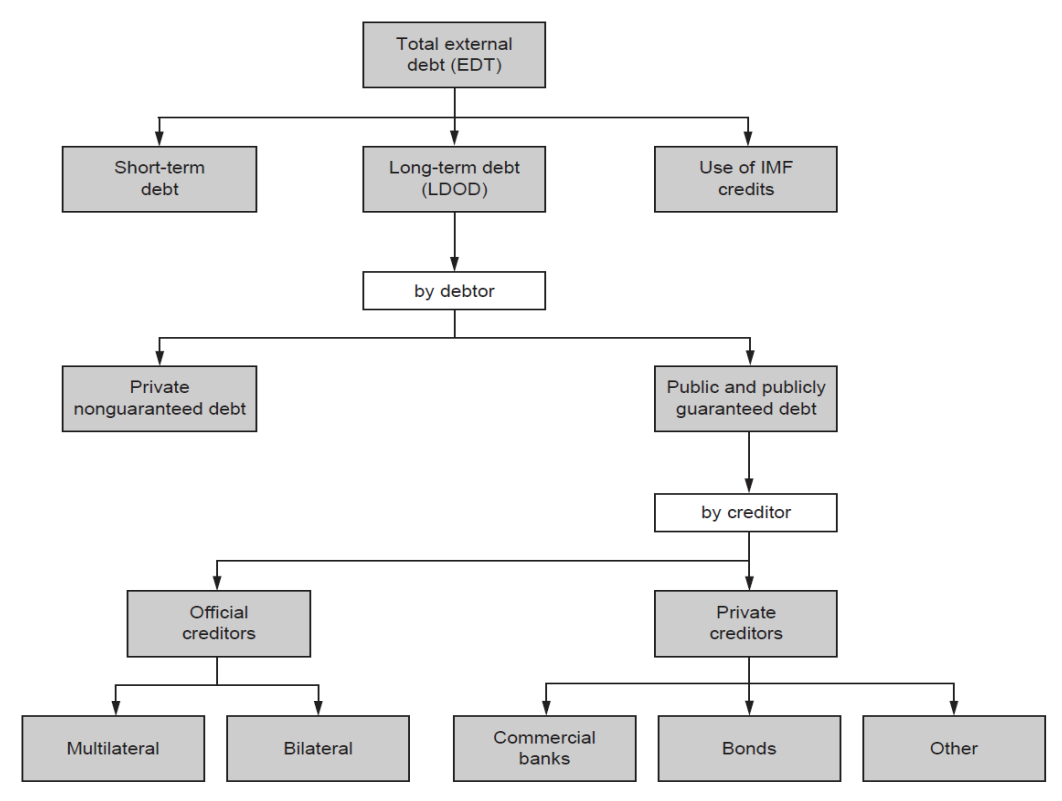

FIgURE 1. Decomposing Net Debt Flows into Public and Private Components (GDF Database)

or private status of the creditors in the PPG debt but not of the debtors. We consider all PPG debt borrowers "sovereign", because no split exists into "public" or "publicly guaranteed" parts. Unfortunately, the level of detail in the GDF database does not allow to classify the short-term debt into private or public. We assign the GDF's shortterm debt item to private flows with the caveat in mind that it might contain some public part. $^{21}$

The most important issue with the GDF database, however, is the fact that it covers the data only for the countries which are considered developing (by the WB) at the moment a given vintage of the GDF is released. If a country is reclassified by the WB as a "high-income country" it is no longer included in the database. ${ }^{22}$ We use the historic vintages of the GDF, which are available at the official GDF Archive website (http://data.worldbank.org/data-catalog/international-debt-statistics) with the earliest vintage available is as of November 2005 to find out who was in the database before and who is there now. However, since we do not use resources which are not readily available to researchers, we do not try to supplement the data for countries, such as Cyprus, Hong Kong, Israel, Korea, and Singapore, that were re-classified as

21. GDF does not provide information to decompose short-term flows. We used different assumptions, the most conservative from the point of view of our exercise, was to assign it to private flows.

22. For example, the note on the November 2007 vintage of the GDF (available online at http://data.worldbank.org/data-catalog/international-debt-statistics) explicitly says: "Barbados, Czech Republic, Estonia, and Trinidad and Tobago are no longer included in the database as they were reclassified in July [of 2007, our comment] as high-income countries." 
high income and dropped from the GDF earlier. We code these countries' debt as missing. ${ }^{23}$

Finally, the OECD Development Assistance Committee (DAC) database is the source of information on official development assistance (ODA). It provides comprehensive data on the volume, origin, and types of net development assistance ("aid") and other resource flows for "aid-eligible" recipient countries in developing world. These aid flows consist of total grants and concessional development loans for the objective of economic development and welfare. For this reason, not all aid-like flows are ODA-eligible and reported. Further data details and issues as well as the definitions of our measures of capital flows are described in Appendix A.

\subsection{Measuring Country Productivity}

For productivity growth, we use average of the annual per capita GDP growth, both the actual rate and relative to the U.S. We also use the "productivity catch-up" relative to U.S $(\pi)$, computed following Gourinchas and Jeanne (2013) as $\bar{A}_{2000} /\left(g^{*} \cdot \bar{A}_{2000}\right)-1$, where $\bar{A}$ is the value of the Hodrick-Prescott trend component of productivity estimate $A_{t}$ and $g^{*}$ is the annual TFP growth observed on average in the U.S. between 1980 and 2000 (See Appendix A for more details).

\subsection{Samples}

We start with the largest possible sample where we obtain the data from official and readily accessible sources. Then we perform the formal econometric outlier tests to detect influential observations. These tests are designed to detect the observations that i) have large residuals, or ii) have an extreme value of a predictor variable, compared to the sample mean, or iii) could be considered "influential", that is, if removing the observations, one at a time, substantially changes the estimate of coefficients.

An alternative approach would be to exclude the countries who are objectively atypical, such as the countries with population below a certain threshold, offshore financial centers, the countries with a large share of exports coming from oil, minerals, and other commodities, or the countries with protracted political or economic instability (wars, political and economic crises, hyperinflation, etc.). These observations will typically be visible in partial correlation plots. In the earlier NBER working paper version of this paper (WP17396) we followed this approach. In the current version we use the formal outlier tests to detect outliers. ${ }^{24}$ It turns out that both approaches lead to detection of similar influential observations.

Our largest sample is a 156-country "Raw World" sample which includes 22 advanced OECD countries and all non-OECD countries where data on current account

23. The World Bank classified these as high-income countries based on per capita income levels even ahead of Portugal and Greece; See http://data.worldbank.org/about/country-classifications/a-short-history.

24. We thank to an anonymous referee for suggesting this. 
balances and GDP per capita is available for at least 13 years, 48 percent of the time, over the sample period 1980-2007. ${ }^{25}$ The 134-country "Raw Developing" sample excludes 22 advanced OECD countries from the "Raw World" sample. We do keep in this sample such rich countries as Singapore, Israel, Cyrpus, Korea (an OECD country) to be consistent with the developing countries used in the literature. The 108country "Developing" sample is "Raw Developing" sample minus countries whose data for the components of capital flows necessary for our decomposition exercise (equity and public and publicly-guaranteed debt) are missing in all years over the 1980-2007, minus the outliers in terms of CA/GDP and growth based on the formal outlier tests. These tests remove the "influential" observations based on the DFITS statistics (Welsch and Kuh 1977) and Cook's D statistics (Cook 1977). In addition, we follow the recommendation of Belsley, Kuh, and Welsch (1980) and delete countries whose inclusion or exclusion into regression changes the regression coefficient a lot based on their measure of influence DFBETA. The details of these tests and descriptions of samples are in Appendix B.

Our main 98-country "Benchmark" sample starts from this "Developing" sample and then removes "influential" observations in terms of debt components needed for the decomposition exercise using same exact outlier tests. We use this 98 country sample throughout the paper. We also checked whether results are sensitive to using a subset of the "Benchmark" sample, where we drop countries with the average population less than 1 million, as it is usually done in the literature. Dropping these countries mean that we drop more than $12 \%$ of the sample. There is a priori no reason to drop these countries especially because they were not picked up by the formal outlier tests. However, we want to verify if our results are sensitive to the presence of small countries. We also tried dropping countries with populations less than 0.5 million and 0.25 million but report the results with a more conservative filter of 1 million.

For robustness, we also tried constructing the samples with even a larger crosssection of countries which would still allow us to calculate some reasonably reliable longer-term averages. For that we build the "Raw World" sample from the countries with the CA/GDP and growth data available for a minimum of 10 years over the 1980-2007 obtaining 165 countries. We then move on constructing the sub-samples as described above by performing formal outlier tests. We show results with these samples in Table 3, but our core analysis centers on the 98 country sample that uses data available for at least half of our sample period.

Finally, we use other samples, that are smaller than our 98 country "Benchmark" sample but are frequently used in the literature. The "PWT" sample is a 67-country subsample of "Raw Developing" sample where capital stock estimates, based on the data from the Penn World Tables (PWT) version 6.1, are available most of the time. The "1970" sample is a 46-country subsample of "Raw Developing" sample with data

25. If we move the threshold one year up to 14 years, we will lose many Eastern European countries since they did not exist as countries. It is important to keep these observations since they are typical emerging market countries, where they imported capital during their growth phase. 
for GDP, total foreign assets and liabilities, foreign reserves (excluding gold), and stock of PPG external debt are non-missing since 1970 and 1970 GDP per capita is less than 10,000 of 2000 US dollars. Details of the variable calculations are in Appendix A and the countries included are listed in Table 2.

\section{Descriptive Patterns}

We start by presenting descriptive statistics that show a broad picture of international allocation of capital and then we move to regressions for a more systematic analysis.

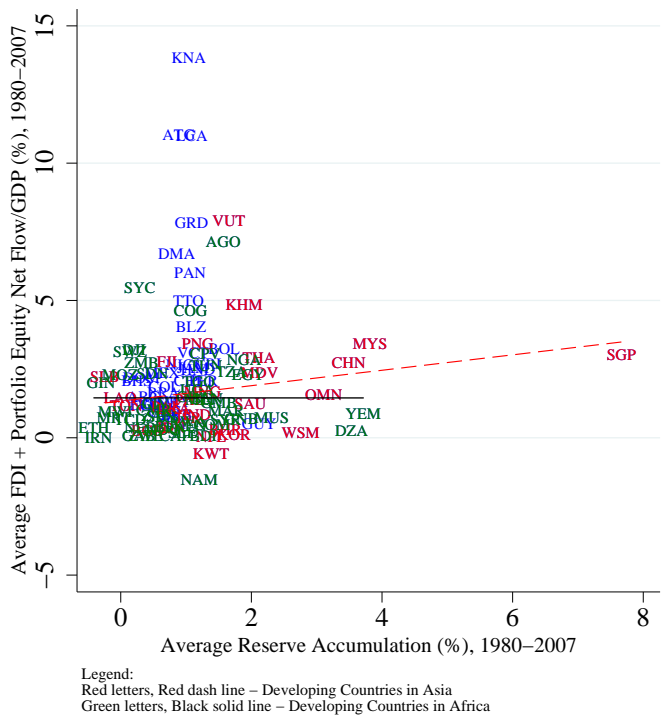

FIGURE 2. Net FDI and Portfolio Equity Flows and Reserves

Figure 2 shows that countries could be net borrowers and net lenders at the same time, depending on the type of flows. There is a strong positive correlation between net equity (FDI plus portfolio) flows and reserve accumulation for Asian countries (the slope is positive without Singapore) but not for other emerging markets. This means that Asian countries are simultaneous net borrowers in terms of equity flows and net lenders in terms of reserve assets. The relationship between private equitytype flows and reserve accumulation is negative for African countries, and there is no relation between these two variables for the rest of the developing countries. For many African countries, capital flows are mostly in the form of development aid, 
A. Zambia

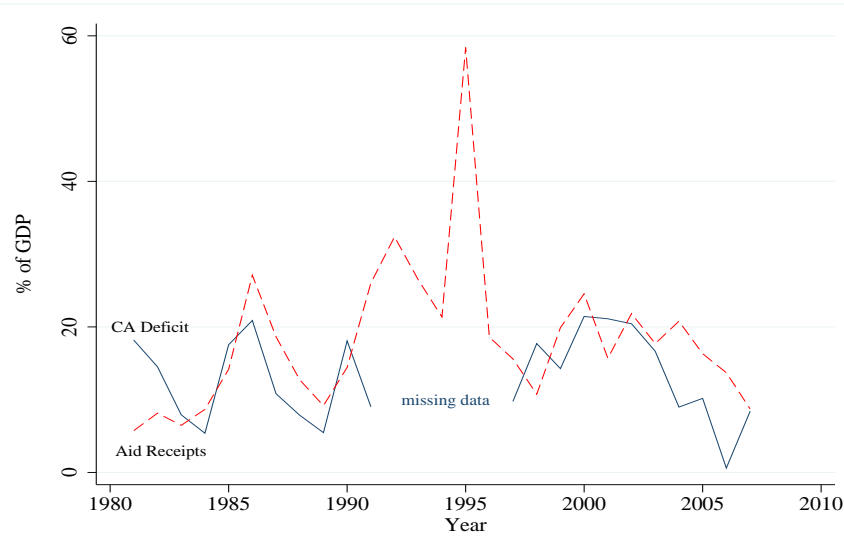

B. Tanzania

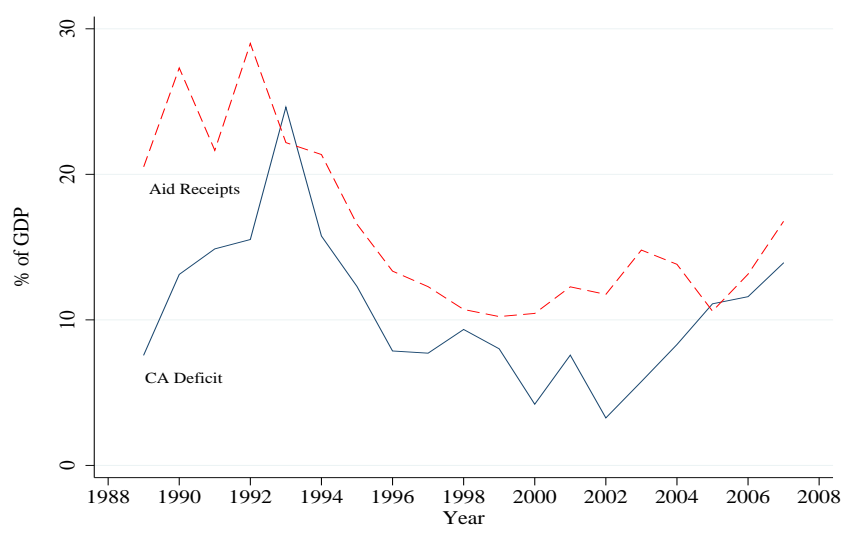

FIGURE 3. Current Account Deficit and Aid: Case of Zambia and Tanzania

where current account and aid flows track each other very closely, as clearly shown in Figure 3 for Zambia and Tanzania. ${ }^{26}$

Next, we divide all countries into three groups according to their productivity growth (measured by the average growth rate of the real GDP per capita over 19702007). Low-Growth countries are those countries with growth rates below 25 th percent quartile $(0.9 \%)$; High-Growth countries are economies with growth rates above 75 th percent quartile (3.2\%); the rest of countries are assigned to the Medium-Growth countries group.

26. These countries are among the largest aid recipients in the region in the amount of $18 \%$ of GDP in Zambia and $16 \%$ in Tanzania. 
Table 1 shows the descriptive statistics for each of the three groups, low, medium, and high growth, for the period-average of the CA balance to GDP, change in net foreign asset position (NFA) to GDP (both with the sign reversed to interpret as capital flows), and their main components. The table relies on the data from the IMF's IFS, marked "IMF", and also the data that are adjusted for valuation effects from Lane and Milesi-Ferretti (2007), marked "LM". For aid flows we rely on the OECD DAC database, and for debt components we use the World Bank's GDF database (details are in Appendix A). Notice that the negative CA is a flow concept available directly from BOP, while the changes NFA are computed from the stock. Not every country is present in every sub-period, as shown in Appendix Table APP-1.

For the longest period 1970-2007, the negative of the current account in the lowgrowth countries averages $5.4 \%$ of GDP; it is $3.5 \%$ in the medium-growth countries and $5.4 \%$ in the high-growth countries, suggesting no definite long-run relationship between productivity growth and CA deficit. This is because low and high growth countries got the same amount of capital glows on average. The same is true for the change in NFA based on the IMF data. A slightly different picture emerges when we look at the change in NFA, adjusted for valuation changes from LM. Here we observe a positive relationship between capital flows and growth since highest growth countries received most of the capital flows during 1970-2007.

Figure 4 helps visualize these patterns by presenting the number of net-borrower and net-lender countries in this sample by year and over the entire period 1970-2007. Clearly, as seen from Panel A, net debtors dominate in the developing world. The more striking is what we show in Panel B, where countries with growth rates higher than sample average (in cross section or year-by-year) are predominantly net borrowers as predicted by the neoclassical theory.

In columns (5) and (6) of Table 1 we report the FDI and portfolio equity flows from two sources. These flows, that are clearly private, are positively correlated with growth. As seen in columns (7) and (8), the same is true for debt flows, regardless of the data source and hence the valuation adjustment.

Columns (9) to (11) show a negative relation between aid receipts and growth, and a positive one between two measures of reserve accumulation and growth. ${ }^{27}$ Therefore, low-growth countries are net recipients of debt in the form of aid, and high-growth countries seem to accumulate reserves. The broader aggregate "reserve and related assets" in column (10) includes the transactions with reserve assets, exceptional financing, and use of the IMF credit and loans. The item "reserve assets" includes more liquid external assets readily available to and controlled by the monetary authorities. Both measures give the same overall message — a not surprising result given the correlation between the two measures above 0.7. In column (12) we report the item Net Errors and Omissions (NEO), where a negative value is typically interpreted as unaccounted capital outflows, the "capital flight." There seems

27. By the BOP convention, the net accumulation of reserve assets is considered net capital outflow and has a negative sign in the BOP statistics because it involves a purchase of foreign assets. We multiply it by minus one (-1), so that a larger reserve accumulation is represented by a larger positive number. 


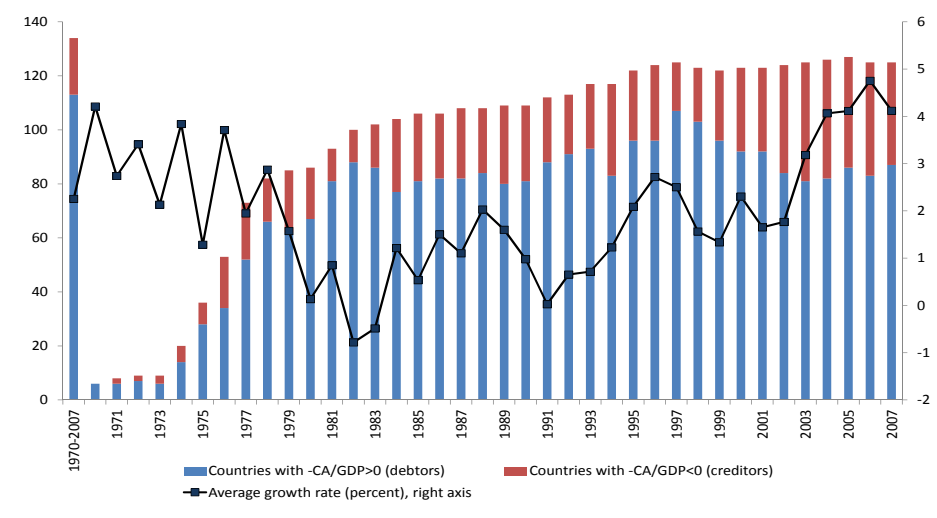

B: The Number of Debtor and Creditor Countries, High-Growth Developing Countries

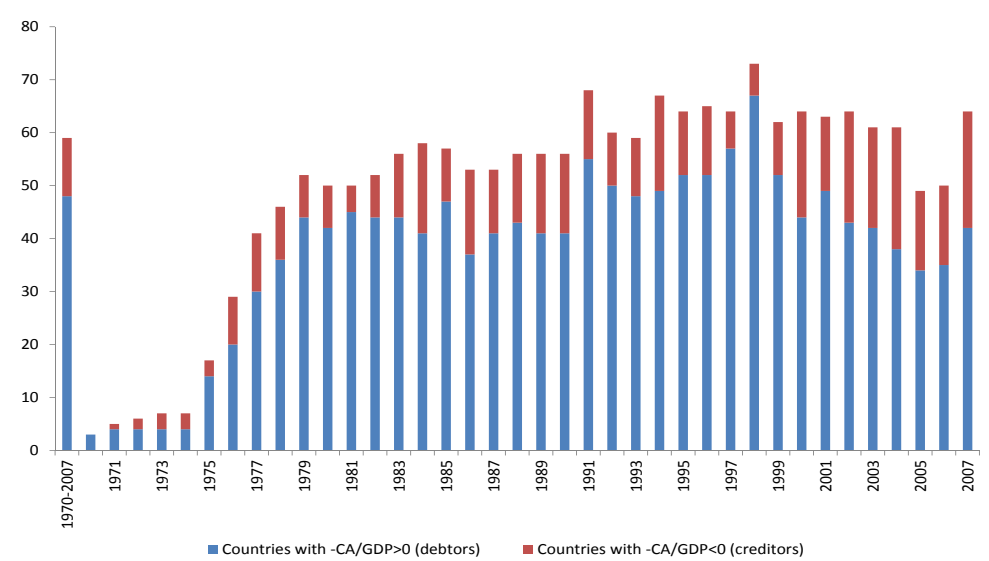

FIGURE 4. Debtor and Creditor Developing Countries: Raw Developing Sample, 1970-2007

to be a weak positive relationship between the NEO and growth: the fastest growing economies experience on average less unrecorded capital outflows.

In column (13), we report a measure for net public debt flows introduced by Aguiar and Amador (2011) and also used by Gourinchas and Jeanne (2013), computed as the period average of the annual changes in stock of public and publicly-guaranteed external debt minus the period average of the annual changes in foreign reserves stocks (excluding gold). The attempt is to get a net international asset position of the overall government, including fiscal authorities and the central bank, where the 
total PPG debt is a proxy of the external public liabilities while the reserves is a proxy for external government assets. We use the narrow definition of reserves for internal consistency because only this aggregate is available in the data as a stock concept, and the PPG debt is also computed from the stock data. The correlation between growth and net government debt during the 1970-2007 seems negative, which means that the fastest growing countries borrow less on net in terms of public debt. This result gets stronger when we focus on a more precise measure of net government debt in column (14), that we call the sovereign-to-sovereign capital flows in the rest of the paper. In this column we do not just use the total PPG debt, which includes some debt flows from private creditors (see Figure 1). Instead, we add up the components of debt which we believe conceptually most closely correspond to the transactions between two public entities, possibly represented by the international donor agencies on the creditor side. The components include the PPG from official creditors (other sovereigns or international agencies) and other forms of sovereign borrowing, such as official development assistance (aid) grants and the IMF credit (the details are in Appendix A). The reserves accumulation is subtracted as before.

To further explore the time-series trends in net capital flows and their main components, we compute averages over shorter time periods. When we look at the sub-periods, no clear pattern jumps out. This is expected given the noisy nature of shorter time span data. However, the periods 1990-2007 and 2000-2007 seem to mimic the general long term trends in all categories of flows, and the private types of flows in column (5)-(6) positively correlate with growth in every sub-period. In addition, columns (11) and (14) clearly show that the low-growth countries borrow (or receive aid) in terms of government debt (liabilities) and middle- and high-growth countries lend in terms of reserve accumulation (government assets).

Next, we present country-by-country data to identify net borrower and net lender countries and the components of capital that drive this behavior. In Table 2, countries from the largest "Raw World" sample of 156 countries are grouped by large geographic regions according to the World Bank classification, and sorted from lowest to highest rate of growth within each region. We also report cross-sectional averages for each region to establish possible regional patterns. We do not report the measures of capital flows adjusted for valuation effects for brevity because the previous results show that the valuation adjustment does not alter the cross-sectional and over time patterns.

In Africa, capital flows are clearly dominated by aid receipts. Once aid flows are subtracted from CA, there is capital flight on average out of this region that has experienced low growth rates on average. This is the predicted outcome of the standard theory.

An interesting pattern emerges in Asia: in contrast to the common view, only 4 high-growth countries are net savers: China, Korea, Malaysia, and Singapore. These countries, however, are all net borrowers in terms of equity while their public saving (the negative of the public debt) find their way in the accumulation of reserves. Comparing these countries to other fast-growing countries, like Cambodia or Lao PDR, shows the latter heavily rely on aid and public debt and do not stockpile reserves. 
Countries in Europe and Central Asia include mostly emerging market economies. While some (e.g., Albania, Armenia, Kyrgyzstan) rely heavily on aid, for most of these countries aid is a small portion of GDP. More importantly, both private flows and public debt seem to follow the prediction of the neoclassical model exhibiting a positive correlation with growth. The similar behavior of private flows and public debt flows is visible in countries of Latin America. There, the positive correlation between growth and aid-adjusted net capital flows is strong.

An interesting feature of the African and Latin American countries is a clear difference between the narrow reserve assets aggregate and the broader one, including "reserve-related items" (exceptional financing and use of the IMF loans). These countries have relied more on the multinational financing for various reasons (lower income countries, debt crisis, etc.). For the rest of the countries the difference is immaterial. For completeness, the table shows industrial countries. All of the rich countries with the above average growth are net borrowers except Japan, Finland, and Norway.

We find similar patterns for the 1990-2007 and 2000-2007. Although now we have 7 countries in Asia that display current account surpluses (Indonesia and Thailand are added to the previous 4 during the 1990-2007 and India added to this list during the 2000-2007). The broad patterns remain the same. These countries are net borrowers in FDI, and their government behavior, in particular reserves minus government debt, is the main driver of the current account surpluses (results for 19902007 are available upon request).

\section{Regression Analysis}

\subsection{Total Net Capital Flows and Growth}

We start with the sample where we have at least 10 years of CA and GDP growth data over the 1980-2007. As we mention in Section 2.3, in the rest of the paper we apply a more stringent criteria, where we have the data for at least half of the sample. The reason we start with the sample with less stringent requirement to time-series is to see the results on total capital flows and growth in the largest cross-section of countries. This is important since certain countries that are net exporters of capital, such as Hong Kong, will enter only into this sample since the official current account data for Hong Kong starts in 1998 in the IFS database, our main source of the BOP data.

Panel A of Table 3 presents the bivariate OLS regressions of capital flows on productivity growth. Column (1) and the corresponding partial correlation plot in the upper-left part of Figure 6 show that there is a positive significant relationship between net capital flows and growth when we look at the largest possible world sample. Column (2) shows the same result, although somewhat weaker statistically 
(only at $15 \%$ significance), for the largest possible sample of developing countries. ${ }^{28}$ Both column (1) and column (2) results can also be driven by outliers as hinted by upper-left sub-panels of Figure 6. Thus, we undertake the formal econometric outlier tests to detect influential observations. Column (3) uses a sample that is a subset of developing country sample in column (2), where we drop the outliers in terms of CA/GDP and growth detected by these formal outlier tests. Column (3) also drops the countries which we do not have any data on the key components of financial account of the BOP. We need the data for these components to present a decomposition of total flows. The sign is still positive in the regression and the pattern is of weak positive relationship between total flows and growth, as shown in the upper right partial plot in Figure 6.

In column (4) we perform the formal outlier tests for the components of capital flows that we will use for the decomposition exercise such as FDI and public debt. The coefficient is still positive but given the size of the standard errors it is insignificant at conventional levels. We also check what happens if we drop countries with the average population less than 1 million, which eliminates more than $12 \%$ of the sample. There is no particular reason to implement this test because all the outliers in terms of capital flows and growth and components of capital flows are already removed in the previous columns by the formal outlier tests. However, we would like to see if the removal of the small open economies would cause the coefficient to change sign. It does not, as seen in column (5) or the second from the left partial in the bottom of Figure 6.

Overall, the relationship between net flows and growth in the largest possible developing countries samples with at least 10 years of data is weak, oscillating between being positive or being flat. This is a result that is also previously shown in the literature (see Chinn and Prasad (2003), for example). ${ }^{29}$

In columns (6) and (7), we present the regressions in the two smaller "PWT" and "1970" sub-samples used in the literature by, correspondingly, Gourinchas and Jeanne (2013) (GJ, hereafter) and Aguiar and Amador (2011). We cannot end up with these samples if we start with the largest developing sample and perform formal outlier tests. For example, Singapore and Botswana are removed by formal outlier tests in our sample, Hong Kong would be dropped due to missing debt components (as would Cyprus, Israel, Korea too), and removing countries with less than 1 million population would eliminate Fiji and Cyprus. All these countries are in the "PWT" sample given the fact that their capital stock data exists. The only way to obtain these samples is to follow these authors and to use all countries with available data in the Penn World

28. Notice that the statistical significance on this regression becomes 5-10\% again in Panels B and C that run outlier robust regressions.

29. Upon request we can provide additional results using population normalization, where positive significant results are more of the norm. A priori, there is no reason to choose GDP versus population normalization. In fact, we argue that population normalization may be closer to the neoclassical model per worker normalization. The only reason we stay with GDP normalization in this paper is to be able to compare our results to the literature. The point is that in a world sample or in a developing sample, one cannot get a robust relation in any direction. 
Tables for the "PWT" sample, or to use all countries whose data starts in 1970 for the "1970" sample.

In sharp contrast with the previous results in Table 3, the coefficient in "PWT" sample is negative significant, indicating the GJ's well-known allocation puzzle result. In column (7), we show a similar result for the "1970" sample. While the partial plots for these two latter samples indicate that those results are somewhat affected by influential observations such as Botswana, Singapore, Hong Kong, Mozambique and Nicaragua, the outlier-robust regressions in Panels B and C show a similar negative relation between capital flows and growth in the "PWT" sample. Hence the result that growing countries are net capital exporters is robust in the "PWT" sample. The result in "1970" sample gets weaker though in the least absolute deviation (LAD) regression of Panel $\mathrm{C}$ due to the fact that this regression reduces the influence of countries like Nicaragua.

The outlier-robust regression in Panel B is suggested by Li (1985), where it gives a smaller weight to the observations with the large residuals (based on the same Cook's D statistics we used to eliminate the outliers) and the LAD regression estimates the medians. It is reassuring that the coefficient in column (2) gains in significance in Panels B and C, indicating that countries visible in partial of this regression (such as Equatorial Guinea, GNQ, and Bosnia and Herzegovina, BIH) do not drive the OLS result in Panel A. The qualitative results in columns (3)-(5) do not change between Panel A and Panels B and C since these columns already removed the outliers using the same formal econometric test that underwrites the outlier robust regression. ${ }^{30}$

Table 4 follows the same approach building samples as does Table 3 but here we start with the "Raw World" sample, where countries have data on CA and GDP half of the sample period (at least 13 or more years during the 1980-2007). Hong Kong does not make it to this sample, for example, since it's data starts in 1998 in the IFS. In fact, this is the sample we use throughout the paper, including in Table 1 and 2. The coefficient estimates from Table 4 still indicates a weak positive relationship between capital flows and growth. All the partial plots for the OLS regressions are reported in Figure 7, indicating overall similar patterns. The bottomline is that the relationship between net flows and growth in the largest possible developing country samples with at least 10 or 13 years of data between 1980 and 2007 is weakly positive and/or flat. ${ }^{31}$

30. It is important to understand why Singapore and Botswana are picked by the formal outlier test in our large sample-hence they do not appear in our developing sample of column (3)- and at the same time these countries do not affect the results of the outlier robust regressions of Panel B and C for the PWT sample. These countries, as well as Hong Kong, are also detected as outliers in the PWT sample when we perform the outlier tests (available upon request). We did not drop them to have the exact sample, PWT, as GJ. The outlier-resistent regressions deal with outliers rather differently instead of dropping them. These regressions are weighted regressions where outliers get smaller weight but not entirely eliminated. In our larger sample dropping them or running outlier robust regressions give similar results as shown in column (2) all panels, where we include these countries.

31. We restricted the main analysis to the pre-Great Recession period. This was mostly for practical reasons (delays in data availability and revisions of most recent data). However, if we define the samples as 1990-2010, or 1995-2012, instead of 1980-2007, it will be the same weak positive result but now we will be using data over the entire sample of 20 years. These results are available upon request. 


\subsection{Decomposing Net Capital Flows: FDI, Portfolio Equity, and Debt}

In order to understand why the relation between total flows and growth is weakly positive in large developing country sample but is strongly negative in the "PWT" sample, that is mainly composed of Asian and African countries, we decompose the total flows into more disaggregated components. A closer look (for example, on partials in Figure 7) immediately makes it clear that the low-growth countries are mostly in Africa and the high-growth ones are in Asia. If we combine these observations with the statistics in Tables 1 and 2, it becomes clear that most of these patterns are driven by the dichotomy between private and public capital flows. The detailed decomposition of capital flows into public and private components helps us understand why the relation between capital flows and growth can be negative (capital flows out), positive (capital flows in), or zero, conditional on the sample used for these correlations.

The first decomposition of net capital flows is to separate FDI and portfolio equity flows from debt flows. Conceptually, net FDI and portfolio equity flows are private flows and debt flows is a mix. Table 5, columns (1) and (2) show that the relation between private capital flows, measured as net FDI plus portfolio equity flows, and growth is positive in our benchmark sample of 98 countries, regardless of the fact that we use IMF or LM data, the latter adjusting for valuation effects. Using our detailed decomposition of debt into private and public components, we add the debt coming from private creditors and obtain a combined measure of private capital flows across all asset classes. This broad measure of private flows is also strongly positively related to growth, as shown in column (3) and (4), and with larger point estimates. ${ }^{32}$ All these columns also show high coefficient of determination R-square highlighting the important role of growth in explaining private flows.

The estimates for private capital flows are also economically meaningful. Take two countries, Mali and Turkey, the first in 25th percentile and second in 75th percentile in the distribution GDP growth over the sample period. Mali grew at a rate of 0.5 percent annually where Turkey grew at a rate of 2.6 percent annually during our sample period. Multiplying the difference in these growth rates by our estimated coefficient of 0.9 from column (3) gives us a predicted effect of change in growth from 25 th to 75 th percentile on net private capital flows of 1.8. The actual difference between the 25 th and 75th percentile in the distribution of private capital flows is 3.0. Hence, our estimates imply that the $75 \%-25 \%$ range of growth explains $60 \%$ of the $75 \%-25 \%$ range in private capital flows data, which is sizeable. ${ }^{33}$

32. The details of this decomposition are spelled out in the previous section, next section and also in Appendix A. The correlation of growth with a measure of total debt, computed from differenced valuationadjusted stocks of portfolio debt and other investment from the LM dataset, is positive but much weaker (the coefficient is 0.22 with t-stat of 1.3 ) because total debt combines the private and public components.

33. To give a slightly different prospective on the experiences of these two countries we compare their level of total private capital flows in the beginning and the end of our sample, the 1980-2007. During the first five years of the sample the average private flows to GDP of both Mali and Turkey were roughly $0.5 \%$; 
Column (5) focuses on net public debt component, measured as public and publicly guaranteed debt minus reserve accumulation. The negative significant coefficient of growth confirms statistically the general pattern we see in Table 1 and is consistent with the model of Aguiar and Amador (2011), where the negative relation between net (total) capital flows and growth is driven by public debt flows. These patterns are not driven by outliers as seen from the partials in Figure 8, where the dashed red line superimposes the same regression line that uses "Benchmark" sample minus countries with less than 1 million average population. Notice that none of the countries visible in corners are outliers according to the formal outliers tests. The same story is told by the outlier-resistant LAD regressions in Panel B.

\subsection{Decomposing Net Debt Flows: Public versus Private}

In Table 1 we introduced our measure of net sovereign-to-sovereign debt flows consisting of the PPG from official creditors, official aid grants, and the IMF credit, net of reserves. To further explore the role of sovereign-to-sovereign debt flows, we decompose net debt flows, into their components exploiting the detailed data available in the WB-GDF and OECD-DAC databases (see Appendix A for details). Table 6 shows the results. Panel A shows a positive relation between total external debt, both long-term and short-term, and growth. The coefficient of total short-term debt in column (2) is significant positive, but GDF does not allow to further decompose these flows, see Figure 1. In contrast, the long-term debt flows in column (1) can be further divided into total PPG debt from official creditors and also PPG debt from private creditors.

Panel B reports the results with several measures of sovereign-to-sovereign debt flows. Debt flows from bilateral and all official (bi- and multilateral) creditors based on the WB-GDF data both show a negative correlation with growth as shown in columns (1) and (2) of panel B. Columns (3) and (4) of Panel B rely on alternative data sources and show a very strong positive correlation between growth and reserve accumulation from the IMF's IFS database and a very strong negative correlation between growth and aid receipts from the OECD's DAC database.

Motivated by these findings, Panel C solely focuses on private debt flows. Columns (1) to (3) rely on the GDF database. Column (1) of Panel C shows a positive correlation between growth and private non-guaranteed debt flows (the leftover of the total longterm debt after the total PPG debt is subtracted). The same result is also true for PPG debt that comes from private creditors as shown in column (2). Column (3) adds these two measures together to obtain a broader measure of public debt that comes from private creditors. As shown, this measure is strongly positively correlates with growth and registers a high $\mathrm{R}$-square.

in the last five years Turkey's ratio was $6.6 \%$ while the one of Mali was at $2.3 \%$. Our estimates explain a large portion of this divergence as a function of different growth experiences of Mali and Turkey. 
Column (4) shows the same fact from a different perspective, namely, by subtracting total aid flows reported by OECD-DAC database (the measure in column (4) of Panel B) from net total capital flows (the CA with the sign reversed). We arrive at the same positive relation between growth and total private flows since many parts of PPG debt that come from official creditors overlap with aid flows as shown in Appendix Table APP-2. Partial correlation plots (available on request) show that none of these regressions are driven by outliers. Appendix Table APP-3 shows a similar decomposition for aid flows from the OECD-DAC, where all of the components are negatively correlated with growth.

To summarize, the negative correlation between growth and total capital flows is entirely driven by sovereign-to-sovereign borrowing and lending. Our results clearly show that the flows that can be defined as private or market-driven (private nonguaranteed debt, private but publicly-guaranteed debt, total debt from private lenders, or even public debt from private lenders) behave as predicted by the basic neoclassical theory, in the sense that these flows are positively correlated with growth.

\section{Reconciling with the Literature}

Our findings show that the relation between total capital flows and growth is weakly positive and mostly statistically insignificant. This is because net total capital flows is composed of private and public capital flows, and, as we show, the correlation of each of these flows with growth has the opposite sign. However, we also show that in the "PWT" sample, there is a strong and robust negative relation between total net capital flows and growth. In this section, we replicate results of GJ, who used "PWT" sample with GJ's officially released data and our data. There are other differences in our approaches such as measuring external debt and productivity growth, and we want to make sure the reasons for the different results is the sample composition and not different measurements of key variables.

There are a number of differences in the GJ's approach from ours, in addition to the fact that they use a sample of $67 / 68$ countries whereas we use a benchmark sample of 98 countries. First, they compute total flows as initial debt stock $d_{0}$ minus cumulated annual CA balances while we use the average of the annual CA balances; second, they express annual CA balances in PPP international dollars as in PWT while we use the CA balances in nominal dollars as they come from the IMF-IFS; third, they normalize the cumulated flows by the initial GDP while we normalize each annual flow by the corresponding annual GDP; and fourth, they use a measure of crosscountry productivity growth instead of average per capita GDP growth. Their PPPadjusted cumulated and normalized by the initial GDP measure of total capital flows is on average $31.5 \%$ of the initial GDP in their sample (varying from -197 to $134 \%$ ). Their measure of productivity catch up is on average -0.10 (varying from -0.62 to $0.85)$.

Table 7 starts with replicating results of GJ using the their data released online as the web-appendix to the published paper (marked "GJ-REStud" in the header of the 
table) in column (1). Column (2) runs their exact regression using our data where we compute the variables over the same time period (the 1980-2000), from the same data sources, and by the same methods, as in GJ (marked "AKV"). Comparing the results in columns (1) and (2) we find a very similar negative correlation between productivity catch-up parameter $\pi$ and total capital flows, except weaker significance due to the fact that we do robust standard errors. ${ }^{34}$

In columns (3) and (4) we use our main measure of productivity, the average per capita GDP growth, and find a similar negative correlation. Doing exactly the same regression in our bigger benchmark sample of 98 (93 since we lose some countries due to the missing control variables used by GJ), we find a positive and weakly significant correlation between total capital flows and growth, as shown in column (5). This result is identical to the one showed in Table 4 but here the flows variable is measured as in GJ and we control for other regressors. All in all, the crux of the matter is not about using productivity catch-up or simple growth differences across countries, which is not surprising given that the correlation between the two measures of productivity is above 0.8 .

Table 8 replicates the decomposition exercise of GJ, which is again very different than our exercise. They compute PPP-adjusted cumulated public debt flows as they did with total flows, where public debt flows they measure as PPG debt minus reserves. Their private flows measure is then a residual after these cumulated public debt flows is subtracted from total flows of Table 7.

As before, we replicate GJ results using the GJ's official data in column (1) and (2) of Table 8 and we again match their point estimates reported in their Table 6, columns (2) and (4) [p.1507] for public and private flows respectively. ${ }^{35}$ Column (1) shows result similar to what we show in the 98 country sample. Public flows measured as PPG minus reserve accumulation, computed by the GJ's methodology, negatively correlates with productivity catch-up. The private flows, computed as the total flows minus the measure for public flows form column (1), correlates positively with productivity catch-up, as GJ report too. These results do not change if we use our estimates of GDP per capita growth instead of productivity catch-up, but otherwise use the GJ's data and methodology, as seen in column (3) and (4).

We again confirm that the choice of a proxy for productivity does not influence the outcome for the decomposition exercise. We find much weaker evidence of the negative correlation of public flows and productivity and positive correlation between private flows and productivity in the smaller "1970" sample, using our data and the

34. Column (1) in our Table 7 is the exact match of GJ's Table 2, column (3) [p.1497] with the coefficient significant only at $10 \%$ level. In the Appendix Table APP-5, we replicate GJ's Table 2 using published GJ codes and data exactly when we use the OLS standard errors like them. So the difference in significance is due to robust standard errors used in our code.

35. GJ use a 68-country sample for the total flows regressions in their Table 2 and a 62-country sample for the decomposition regressions in their Table 6. The difference between their 68- and 62-country samples is the exclusion of 6 countries (Angola, Hong Kong, Iran, Mozambique, South Africa, and Taiwan) whose data is not available over the whole sample period, the 1980-2000, as stated in GJ. 
same methods as GJ. The latter results qualitatively fit what Aguiar and Amador (2011) report. ${ }^{36}$ We conjecture that in small samples, robust standard errors may result in the loss of statistical significance since this way of calculating residual private flows is very fragile.

In Table 9 we confirm our conjecture by presenting results that explain why the residual methods of calculating private flows may give different results in different samples depending on the residual method employed. The table presents a similar exercise in four-column blocks corresponding to the three main samples we consider in this paper: the "PWT" sample as in GJ, the "1970" sample and, for completeness, our "Benchmark" sample. In each of four columns we calculate the private flows as a residual, but each column sequentially subtracts more components of public flows from total capital flows. In this table we use our approach to deflating flows since we already showed that it does not matter how you deflate or normalize. It also does not matter if we use the productivity catch-up measure or GDP growth.

Notice that in all samples the magnitude of the point estimate increases as we "clean" the residual private flows more and more by subtracting a variety of public flows. The latter are negatively correlated with productivity, as we showed before, and thus push the slope to zero. Columns (4), (8), and (12) deliver a positive significant correlation between private capital flows and growth in all three samples, regardless of the sample size and composition, and regardless of other controls. This is because in these columns we clean all the sovereign-to-sovereign flows, and hence the remaining residual private flows measure is least contaminated by public flows. Notice also how robust is the coefficient, between 0.8 and 0.9 , regardless of the sample size.

If we do not subtract all the public flows, the residual measure of private flows will poorly correspond to the direct measure of private flows and might lead to an insignificant relation between private flows and growth, as shown in columns (1)-(3) and (5)-(7). In the larger sample, the coefficients in columns (9)-(11) are always positive significant even with the less clean measures of private flows since the standard errors are smaller in the larger sample. But the significance and point estimate increases from column (9) to (12) as we clean more and more public flows in the calculation of private flows.

Table 10 revisits our original approach, where private flows are measured directly, as the sum of FDI and portfolio equity, with or without private debt (columns (1)-(2) vs (3)-(4)), but now over the 1980-2000. It shows the same result of positive correlation between growth and private capital flows, with and without controls (panels A and B). Notice that R-squares are between 0.12 and 0.26 and the coefficients are stable around 0.3-0.4 depending on other controls. In Table 5, we showed results with direct method of calculating private flows with similar R-squares but higher coefficients (0.9) since that table uses data up to 2007. What is very nice is the fact that when we use the residual method to measure private flows, we also have a coefficient between 0.4

36. Aguiar and Amador (2011) use a different method to compute long-run public capital flows. They use the change in the ratio of public net foreign assets to GDP between 1970-2004. Our unreported regressions with such measure show that the qualitative results remain the same. 
and 0.9 , similar to the results in the current table. Recall that coefficients around 0.9 explain 60 percent of the variation in the data, which are economically very meaningful effects.

\section{Discussion}

From the shutdown of the international capital markets in the 1930s up until the mid-1970s, debt flows to developing countries were generally restricted to international organization/government-to-government loans. During the late 1970s, after the collapse of the Bretton Woods system of fixed exchange rates, banks joined governments as lenders to developing countries. Following the 1982 debt crisis, the late 1980 s and the 1990 s witnessed reductions in legal restrictions to foreign capital as well as a variety of financial innovations, partially to circumvent the remaining restrictions. A new wave of easy access to cheap international credit found the U.S. current account deficit at the core of so-called "global imbalances," with current account surpluses in oil-producing countries, China, and other Asian countries taking the bulk of the "other side"-all under intense criticism related to exchange-rate intervention.

During these last decades, questions of "where" the capital flows and "why" we observe particular patterns have been investigated by many researchers, both in empirical and theoretical settings. ${ }^{37}$ Whether or not capital flows are positively associated with growth and productivity - both in terms of capital flowing to highgrowth countries and of foreign capital promoting further growth upon arrivalseems to be elusive. Chinn and Prasad (2003), for example, find either no relationship or a nonrobust relationship between current account deficits and growth in a broad sample of developing and industrial countries between 1970 and 1995 while Prasad, Rajan, and Subramanian (2010) find different estimates depending on the sample of developing countries (for instance, whether or not the sample includes Eastern Europe) and time frame. Calderon, Chong, and Loayza (2002) find no relation in a cross-section of 44 developing countries, yet in a time-series they find that growing countries are net receivers of capital flows and run current account deficits. Dollar and Kraay (2006) find no puzzling behavior in a broad sample of 90 countries between 1980 and 2004 once they dummy out China; they find capital flowing to productive countries and also from rich to poor countries. Other papers-focused on private foreign investment, such as FDI, instead of current account-find a positive correlation between capital flows and growth. ${ }^{38}$

37. There is an extensive literature on this topic; see Obstfeld (1986, 1995), Calvo, Leiderman, and Reinhart (1996), Obstfeld and Rogoff (2000), Obstfeld and Taylor (2004), Edwards (2004), Reinhart and Rogoff (2004), Prasad, Rajan, and Subramanian (2006), Henry (2007), Lane and Milesi-Ferretti (2001, 2007), Alfaro, Kalemli-Ozcan, and Volosovych (2008), Forbes and Warnock (2012), and Gourinchas and Jeanne (2013), among others.

38. See Alfaro, Chanda, Kalemli-Ozcan, and Sayek (2004). 
Facts and Theories. Let us start with capital inflows into low-productivity developing countries in the form of aid. A broad literature on the political economy of aid flows has stressed political motivations (Alesina and Dollar, 2000; Arslanalp and Henry, 2005; and Kuziemko and Werker, 2006). An important strand of this research questions the incentives of and lack of accountability by donors and recipients. Easterly (2006), for example, argued that donor agencies such as the World Bank and the IMF had favored development projects that were overly expensive and not sustainable. ${ }^{39}$ Arslanalp and Henry (2005) showed that private capital flows had never been a significant fraction of total net resources for so-called "highly indebted poor countries" (HIPCs), nor did the debt relief provided under previous initiatives lead to more FDI; in fact, official flows, such as grants, became more important. These explanations are consistent with the negative correlation between aid (grants and concessional loans) and growth.

We show that, once aid flows are subtracted, there is capital flight out of lowproductivity developing countries. Many papers have considered political economy explanations, the role of expropriation risk, and financial frictions as explanations of capital outflows by the private sector. Khan and Ul Haque (1985), for example, note in an early paper that the relatively larger perceived risk associated with investments in certain countries (in particular, developing ones) due to inadequate institutions and lack of legal arrangements for the protection of private property can account for capital flight. In the same spirit, Tornell and Velasco (1992) account for private capital outflows by noting that the introduction of a technology that has inferior productivity but enjoys private access ("safe" bank accounts in rich countries) may ameliorate the "tragedy of the commons" whereby interest groups have access to a common capital stock. ${ }^{40}$ Alfaro, Kalemli-Ozcan, and Volosovych (2008) provide evidence that institutional quality is the main reason that, over the long term, rich developed countries receive more foreign capital than poor developing ones. Institutions, representing long-term productivity, are the most important determinant of capital flows and can explain the Lucas paradox. Our results in this paper are fully consistent with our previous results on the Lucas paradox, once we account for the fact that poor and low-growth countries such as Haiti or Madagascar receive a lot of capital in the form of aid and public debt from other sovereigns or multinational bodies.

Several recent papers explore capital outflows from high-productivity countries; that is, upstream capital flows. As we have shown, this pattern is not typical of the average emerging market; rather, it characterizes the behavior of a few Asian countries. In addition, private capital does not, on average, flow upstream for highproductivity emerging markets. Recent theory papers, focusing on China, have stressed the role of financial frictions and of firms' self-finance motives to explain

39. The "Meltzer Report" revealed that the World Bank had, by its own criteria, a 73-percent project failure rate in Africa. The report suggested that donors suffered from large bureaucracies and undermined their own programs through (a) failure to coordinate or harmonize with other donors or (b) ineffective monitoring and evaluation systems. See also Bulow and Rogoff (1990).

40. See also Tornell and Lane (1998, 1999). 
capital outflows (see, for example, Song, Storesletten, and Zilibotti, 2011). Other papers focusing on financial market frictions in general include Caballero, Farhi, and Gourinchas (2008), Mendoza, Quadrini, and Rios-Rull (2009), Sandri (2010), and Buera and Shin (2009). Here, the private sector is behind the observed patterns of capital mobility in reaction to various frictions in the economy. Due to legal and financial market imperfections, private firms are financing themselves out of internal saving. Indeed, recent work by Fan and Kalemli-Ozcan (2013) shows that, in Asia, private firms reacted to the financial reform of the 2000s by saving less while stateowned enterprises reacted by saving more. However, this reversal in saving patterns upon the removal of financial frictions was not enough to reverse the aggregate net capital outflows from these Asian countries from 2000 to 2010.

Other researchers focus on the roles that precautionary saving and the risk associated with globalization plays in driving uphill flows, but the lack of empirical support has prevented any consensus on this view. Ghosh and Ostry (1997), Alfaro and Kanczuk (2009), and Durdu, Mendoza, and Terrones (2009) find that it is difficult to explain the build-up of reserves in emerging markets as insurance against the risk of sudden stops. An IMF study by Blanchard, Faruqee, and Klyuev (2009) found that reserves were not used much during the recent crisis.

An alternative set of explanations focusing on neo-mercantilist government policies designed to increase net exports and enhance growth via reserve accumulation seem to better fit the pattern of capital mobility displayed by China and a few other high-growth emerging markets. Dooley, Folkerts-Landau, and Garber (2004) argue that the normal evolution of the international monetary system involves the emergence of a periphery for which the development strategy is export-led growth supported by undervalued exchange rates, capital controls, and official capital outflows in the form of accumulation of reserve assets. ${ }^{41}$ Although exchange rate stability via fixed exchange rate regimes was replaced in the 1970s by a system of floating regimes, there seems to be an epidemic case of "fear of floating," as Calvo and Reinhart (2002) have noted. The emerging markets' reluctance to let their currencies float and let their nominal (and real) exchange rates appreciate is rooted in concerns about the loss of competitiveness. ${ }^{42}$ As documented by Reinhart and Reinhart (2008), policymakers in many emerging market economies over the past decade have opted to limit fluctuations in the value of their currencies relative to the U.S. dollar, using a wide variety of tools, in an attempt to stem the tide of capital flows. As Gourinchas and Jeanne (2013) note, if productivity take-off originates in the tradable sector, net exports are positively correlated with productivity growth.

Aizenman and Lee (2010) investigate the policy implications of learning-bydoing externalities, the circumstances that may lead to export-led growth, and the challenges of implementing such policies. They show that a policy of exchange rate

41. For the few high-productivity Asian countries that are net lenders, National Income identities imply that net exports should be positively correlated with growth (see Rodrik, 2006).

42. Such models are advanced by Dooley, Folkerts-Landau, and Garber (2004), Aizenman and Lee (2008, 2010), Korinek and Serven (2010), and Benigno and Fornaro (2012). 
undervaluation depends not only on the nature of the externality (labor employment in the traded sector versus knowledge creation as a side-product of investment) but also on the state of the economy and its response to sterilization policies. ${ }^{43}$ Even in the case of labor externalities, undervaluation by means of hoarding reserves may backfire if the needed sterilization increases the cost of investment in the traded sector. ${ }^{44}$ The adverse financing effects of hoarding reserves are more likely to be larger in countries characterized by a shallow financial system and a low saving rate. Overall, these are the conditions that apply to many developing countries-for example, in Latin America, which might explain why such policies were not followed there. ${ }^{45}$

Facts: Public and Private Saving and Growth. What about the saving side of the story? Since current account equals saving minus investment, net capital outflows are associated with domestic saving that exceeds investment. For the few highproductivity Asian countries that are net lenders in terms of total capital flows, their saving must be correlated with growth more than with investment. ${ }^{46}$ Our results imply that this positive correlation might be due to a positive correlation between public saving and growth.

Calculating private and government saving for a wide sample of developed and developing countries is difficult because countries vary in their data availability, accounting practices, and government structures. In national income accounting, gross saving is calculated as gross national income less total consumption (private and public), plus net transfers. Private saving can be calculated as a residual; that is, as the difference between gross saving and public saving.

Any measure of public saving should take into account all forms of governmentcentral, regional, and local-and all public firms. In particular, we would like to include the consolidated central government (budgetary central government, extra budgetary central government, and social security agencies); state, local, and regional governments; state-owned enterprises; and financial and nonfinancial public enterprises, including the central bank. ${ }^{47}$ However, different countries define and organize their public sectors differently. For example, the central government may be defined as the general government minus local and regional governments. The consolidated central government would then be equivalent to the general government in those countries that have no local or regional governments or that place the accounts

43. Hoarding international reserves to encourage exports can also reflect competitive hoarding among emerging markets attempting to preserve their market shares in the U.S. and other OECD countries.

44. Keeping the real exchange rate constant calls for the sterilization of financial inflows. Hoarding international reserves impacts monetary policy and thus leads to markedly higher interest rate, thereby reducing capital accumulation in the traded sector.

45. For a recent detailed description of capital flows to Latin America, see Fostel and Kaminsky (2008).

46. The positive correlation between saving and growth is regarded as puzzling from the perspective of the permanent-income hypothesis, since countries with higher growth rates should borrow against future income to finance a higher level of consumption; see Carroll and Weil (1994).

47. Many central banks are independent, but in many developing countries this is a recent tendency and is often de jure rather than de facto. Including the central bank is also consistent with recent studies that consider reserve asset accumulation as part of the government's net assets; see Aguiar and Amador (2011). 
of the local and regional governments under a unit of the central government. A measure of private saving that includes only the central government will then include the saving of both local governments and public enterprises, creating measurement differences. For countries where public saving refers to the general government, public enterprise saving is automatically included in private saving. For countries where public saving refers to the central government plus state-owned enterprises, the saving of the state, local, and regional governments is automatically included in private saving.

Although one would like to use the same definition across countries, this is much easier said than done. Furthermore, restricting the definition of government to the central government (probably the most common government organization across countries) implies that substantial parts of government activity will be left out of the public saving measure (and will later be counted as private saving). ${ }^{48}$ Further differences in measures of public saving - and hence of private savingresult from using commitment versus cash accounting for government activities across countries. Also, fiscal years do not typically correspond to calendar years. With these caveats in mind, we calculate public saving as government revenue minus government expenditure plus grants and other revenue (such as interest, dividends, rent, and some other receipts for public uses) plus accumulation of reserves minus capital transfer payments abroad using data from the World Bank and from BOP by the IMF. ${ }^{49}$ Thus, our measure of public saving includes all net transfers from abroad.

Following Loayza, Schmidt-Hebbel, and Serven (2000), this choice is dictated by (a) the unavailability of information on the disaggregation of foreign grants into current and capital and (b) the relatively minor magnitude of capital transfers in all but a handful of small economies. ${ }^{50}$ All the items are expressed as a percentage of GDP. As a robustness test, we also calculated government saving as cash surplus/deficit (percent of GDP) plus reserve accumulation net transfers. ${ }^{51}$

Private saving is then calculated as a residual; that is, as the difference between gross national saving and public sector saving. Gross saving data is taken from the World Bank. ${ }^{52}$

Panel A of Figure 5 shows the positive correlation between public saving and growth during the 1990-2007 period in the largest "Raw Developing" sample. The

48. See Loayza, Schmidt-Hebbel, and Serven (2000) for various reporting practices for the public sector.

49. The components of government saving are formally defined in Appendix A.

50. Current transfers (receipts) are recorded in the balance of payments whenever an economy receives goods, services, income, or financial items without a quid pro quo. All transfers not considered to be capital are current. Data are taken from World Development Indicators by the WB, and the IMF-IFS.

51. Cash surplus or deficit is revenue (including grants) minus expense, minus net acquisition of nonfinancial assets. We also used the measures described above with and without reserves and/or net transfers. We obtain similar results, which are not reported.

52. It was necessary to combine our data with the earlier data constructed by Loayza, Schmidt-Hebbel, and Serven (2000) because the WDI database did not have consistent data needed to compute pre-1990 private and public saving for all the countries. 
A: Public Saving and Growth

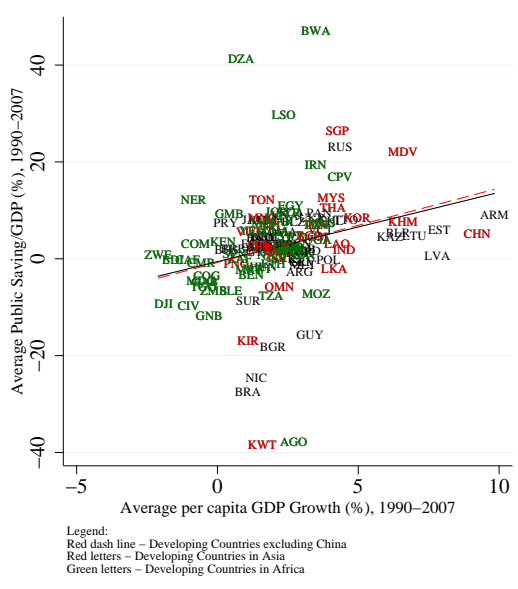

B: Private Saving and Growth

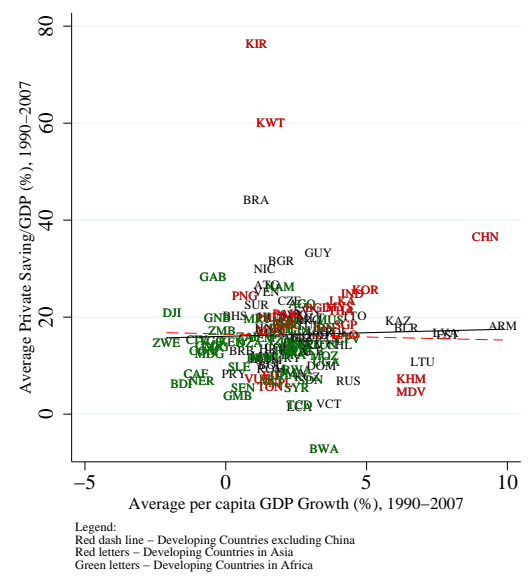

FIgURE 5. Public and Private Saving and Growth in Developing Countries: 1990-2007

regression coefficient (hence the slope) is 1.29 and is significant at 1 percent with a t-stat of 3.89. It is clear that this relation is driven by Asian countries such as Thailand, Korea, Malaysia, Singapore, and China. If we drop China, the slope of the regression (the dashed line) is still significant at 2 percent with a coefficient of 0.89 and a t-stat of 2.48. However, when we look at the relationship between private saving and growth in Panel B of Figure 5, the regression line, shown with a solid line, is virtually flat (with a coefficient of 0.18 and a t-stat of 0.50 ) and becomes slightly negative insignificant when we drop China, shown with the dashed line (with a coefficient of -0.07 and a t-stat of -0.24$){ }^{53}$ These patterns fit with what we have shown so far; namely, that the upstream capital flows from a handful of high-growth Asian countries are driven by government behavior. These results, as mentioned, are consistent with those of Reinhart and Tashiro (2013) and Krishnamurthy and Vissing-Jorgensen (2012). These authors show that central banks in Asia are the ones buying reserves in developed countries and hence they, not private agents, are responsible for the capital outflow (buying safe assets).

53. We verify this relationships in the 125-country Developing sample, which does excludes Algeria (DZA), Botswana (BWA), Kuwait(KWT), Russia (RUS) and/or remove other outliers visible on the graphs. This does not change the qualitative results reported. 


\section{Conclusion}

Countries' trade imbalances, international capital flows, and external debt have always fascinated economists and challenged policymakers. Policy prescription will differ widely depending on the underlying causes of upstream flows and global imbalances. If imbalances are caused by domestic distortions, such as high private saving and low investment due to lack of social insurance and/or shallow financial markets, then a low exchange rate might be justified. If, on the other hand, exportled growth strategies and self-insurance motives are leading to excess reserve accumulation, then we should worry about systemic distortions, with emerging markets' central banks (a) intentionally undervaluing their exchange rates and (b) being, intentionally or unintentionally, destabilizing large investors in the international arena. Correcting domestic distortions requires strengthening social infrastructure and financial intermediation in emerging markets, while excess reserve accumulation necessitates global-level intervention thorough international institutions, as proposed, for example, by Blanchard and Milesi-Ferretti (2009).

Our findings point towards the importance of the latter, where sovereign-tosovereign financial contributions and transfers dominate international transactions and can account for the otherwise puzzling behavior of the capital flows for developing countries over the last 30 years. Our key result is to show that once we subtract all sovereign-to-sovereign flows from the total or directly focus on FDI, equity, and private debt, capital flows are positively correlated with productivity growth which is consistent with the predictions of the neoclassical model. Our findings show that overemphasizing private saving and failing to consider public saving, official flows, and governments' current account targeting as the main drivers of uphill flows and global imbalances are serious shortcomings of the recent theoretical literature.

Our results imply that addressing systemic distortions in the global financial system through international policy coordination should complement-and perhaps even be more important than-fixing domestic distortions in fast-growing emerging markets. 


\section{References}

Aguiar, M. and M. Amador, 2011. "Growth in the Shadow of Expropriation." Quarterly Journal of Economics, 126, 651-697.

Aizenman, J. and J. Lee, 2008. "Financial Versus Monetary Mercantilism: LongRun View of the Large International Reserves Hoarding." The World Economy, 31(5), 593-611.

Aizenman, J. and J. Lee, 2010. "The Real Exchange Rate, Mercantilism and the Learning by Doing Externality." Pacific Economic Review, 15(3), 324-335.

Alesina, A. and D. Dollar, 2000. "Who Gives Foreign Aid to Whom and Why?" Journal of Economic Growth, 5, 33-64.

Alesina, A. and B. Weder, 2002. "Do Corrupt Governments Receive Less Foreign Aid?" American Economic Review, 92, 1126-1137.

Alfaro, L., Chanda, A., Kalemli-Ozcan, S., and S. Sayek, S., 2004. "FDI and Economic Growth: the Role of Local Financial Markets." Journal of International Economics, 64, 89-112.

Alfaro, L., S. Kalemli-Ozcan, and V. Volosovych, 2008. "Why Doesn't Capital Flow from Rich to Poor Countries? An Empirical Investigation." The Review of Economics and Statistics, 90, 347-368.

Alfaro, L., S. Kalemli-Ozcan, and V. Volosovych, 2007. "Capital Flows in a Globalized World: The Role of Policies and Institutions." In S. Edwards (Ed.), Capital Controls and Capital Flows in Emerging Economies: Policies, Practices and Consequences. Chicago IL: University Chicago Press.

Alfaro, L. and F. Kanczuk, 2009. "Optimal Reserve Management and Sovereign Debt." Journal of International Economics, 77, 23-36.

Arslanalp, S. and P. B. Henry, 2005. "Is Debt Relief Efficient?" The Journal of Finance, 60, 1017-1051.

Belsley, D. A., E. Kuh, and R. E. Welsch, 1980. Regression Diagnostics: Identifying Influential Data and Sources of Collinearity. New York: Wiley.

Benigno, G. and L. Fornaro, 2012. "Reserve Accumulation, Growth and Financial Crises," CEPR Discussion Papers 9224. London: Centre for Economic Policy Research.

Blanchard, O., Faruqee, H., and V. Klyuev, 2009. "Did Foreign Reserves Help Weather the Crisis?" the IMF Survey Magazine. Washington, DC: the International Monetary Fund. Retrieved from http://www.imf.org/external/pubs/ft/survey/so/2009/num100809a.htm.

Blanchard, O. and G. Milesi-Ferretti, 2009. "Global Imbalances in Midstream?" the IMF Staff Position Note SPN/09/29. Washington, DC: the International Monetary Fund.

Buera, F. J. and Y. Shin, 2009. "Productivity Growth and Capital Flows: The Dynamics of Reforms." NBER Working Paper 15268. Cambridge, MA: National Bureau of Economic Research.

Bulow, J. and K. Rogoff, 1990. "Cleaning Up Third World Debt without Getting Taken to the Cleaners." Journal of Economic Perspectives, 4, 31-42. 
Caballero, R. J., E. Farhi, and P. O. Gourinchas, 2008. "An Equilibrium Model of 'Global Imbalances' and Low Interest Rates." American Economic Review, 98, 358Ü-393.

Calderon, C. A., A. Chong, and N.V. Loayza, 2002. "Determinants of Current Account Deficits in Developing Countries." The B.E. Journal of Macroeconomics: Contributions, 2(1), 1-33.

Calvo, G., L. Leiderman and C. Reinhart, 1996. " "Inflows of Capital to Developing Countries in the 1990s." The Journal of Economic Perspectives, 10, 123-139.

Calvo, G., and C. Reinhart. 2002. "Fear of Floating." Quarterly Journal of Economics, 107, 379-408.

Carroll, C. D., and D. N. Weil, 1994. "Saving and Growth: A Reinterpretation.T Carnegie-Rochester Conference Series on Public Policy, 40, 133-192.

Chinn, M. D. and E. S. Prasad, 2003. "Medium-Term Determinants of Current Accounts in Industrial and Developing Countries: An Empirical Exploration." Journal of International Economics, 59, 47-76.

Cook, R. D. 1977. "Detection of influential observation in linear regression." Technometrics, 19, 15-18.

Dollar, D. and A. Kraay, 2006. "Neither a Borrower Nor a Lender: Does China's Zero Net Foreign Asset Position Make Economic Sense?" Journal of Monetary Economics, 53, 943-971.

Dooley, M., D. Folkerts-Landau, and P. Garber, 2004. "The Revived Bretton Woods System: The Effects of Periphery Intervention and reserve Management on Interest Rates and Exchange Rates in Center Countries." International Journal of Finance and Economics, 9(4): 307-313, October 2004

Durdu, C. B., E. Mendoza, and M. E. Terrones, 2009. "Precautionary demand for foreign assets in Sudden Stop economies: An assessment of the New Mercantilism." Journal of Development Economics, 89, 194-209.

Fan, J., and S. Kalemli-Ozcan, 2013. "Emergence of Asia: Reforms, Savings, Global Imbalances," Unpublished manuscript, University of Maryland.

Edwards, S., 2004. "Financial Openness, Sudden Stops, And Current-Account Reversals." American Economic Review, 94(2), 59-64.

Easterly, W., 2006. The White Man's Burden. New York: The Penguin Press.

Favilukis, J., S. C. Ludvigson, and S. Van Nieuwerburgh, 2012. "The Macroeconomic Effects of Housing Wealth, Housing Finance, and Limited Risk-Sharing in General Equilibrium." Unpublished manuscript, New York University.

Fostel, A. and G. Kaminsky, S., 2008. "Latin Americat's Access to International Capital Markets: Good Behavior or Global Liquidity?" In K.Cowan, S.Edwards, R.O. Valdes, N. Loayza, K. Schmid (Eds.), Current Account and External Financing. Central Bank of Chile.

Forbes, K. and Warnock, F., 2012. "Capital flow waves: Surges, stops, flight, and retrenchment." Journal of International Economics, 88(2), 235-251.

Frankel, J. 2001. "Comment on Lane and Milesi-Ferretti "Long-Term Capital Movements"." In Ben Bernanke and Kenneth Rogoff (Eds.), NBER Macroeconomics Annual 2001, Vol. 16. Cambridge MA: The MIT Press. 
Ghosh, A. R. and J. D. Ostry, 1997. "Macroeconomic Uncertainty, Precautionary Saving, and the Current Account." Journal of Monetary Economics, 40, 121-139. Gourinchas, P.-O. and O. Jeanne, 2013. "Capital Flows to Developing Countries: The Allocation Puzzle." Review of Economic Studies, 80, 1484-1515.

Henry, P., 2007. "Capital Account Liberalization: Theory, Evidence, and Speculation." Journal of Economic Literature, 45, 887-935.

Henry, P. B. and Peter L. Lorentzen, 2003. "Domestic Capital Market Reform and Access to Global Finance: Making Markets Work." In Litan, Robert E., M. Pomerleano, and V. Sundararajan (Eds.), The Future of Domestic Capital Markets in Developing Countries. Baltimore MD: Brookings Institution Press.

Krishnamurthy, A., and A. Vissing-Jorgensen. 2012. "The Aggregate Demand for Treasury Debt." Journal of Political Economy, 120(2), 233-267.

Khan M. S., and N. Ul Haque, 1985. "Foreign Borrowing and Capital Flight: A Formal Analysis." IMF Staff Papers 32. Washington, DC: the International Monetary Fund.

Korinek, A. and L. Serven, 2010. "Undervaluation Through Foreign Reserve Accumulation : Static Losses, Dynamic Gains." WB Policy Research Working Paper 5250. Washington, DC: the World Bank Group.

Kuziemko, I. and E. Werker, 2006. "How Much Is a Seat on the Security Council Worth? Foreign Aid and Bribery at the United Nations." Journal of Political Economy, 114, 905-930.

Lane, P. and G. M. Milesi-Ferretti, 2001. "The External Wealth of Nations: Measures of Foreign Assets and Liabilities for Industrial and Developing Countries." Journal of International Economics, 55, 263-294.

Lane, P. and G. M. Milesi-Ferretti, 2007. "The External Wealth of Nations Mark II: Revised and Extended Estimates of Foreign Assets and Liabilities, 1970-2004." Journal of International Economics, 73, 223-250.

Li, G. 1985. "Robust regression." In D. C. Hoaglin, C. F. Mosteller, and J. W. Tukey (Eds.), Exploring Data Tables, Trends, and Shapes, 281Ü340. New York: Wiley.

Loayza, N., K. Schmidt-Hebbel, and L. Serven, 2000. "What Drives Private Saving Around the World?" The Review of Economics and Statistics, 82, 165Ü-181.

Mendoza, E.G., V. Quadrini, and J.-V. Rios-Rull, 2009. "Financial Integration, Financial Development, and Global Imbalances." Journal of Political Economy, 117(3), 371-416.

Obstfeld, M., 1995. "International Capital Mobility in the 1990s." In Peter B. Kenen (Ed.), Understanding Interdependence: The Macroeconomics of the Open Economy. Princeton, NJ: Princeton University Press.

Obstfeld, M., 1986. "Capital Mobility in the World Economy: Theory and Measurement." Carnegie-Rochester Conference Series on Public Policy, 24, 55103.

Obstfeld, M. and K. Rogoff., 2000, "The Six Major Puzzles in International Macroeconomics: Is There a Common Cause?" In Ben Bernanke and Kenneth Rogoff (Eds.), NBER Macroeconomics Annual 2000. Cambridge MA: The MIT Press. 
Obstfeld, M. and K. Rogoff, 1995. "The Intertemporal Approach to the Current." In Gene Grossman and Kenneth Rogoff (Eds.), Handbook of International Economics 3 Amsterdam, North-Holland: Elsevier Press.

Obstfeld, M. and A. M. Taylor, 2004. Global Capital Markets Integration, Crisis, and Growth. Cambridge MA: Cambridge University Press.

Prasad, E., R. G. Rajan, and A. Subramanian, 2006. "Patterns of International Capital Flows and Their Implications for Economic Development." In Proceedings of the 2006 Jackson Hole Symposium, Federal Reserve Bank of Kansas City.

Reinhart, C. and Tashiro, T. 2013. "Crowding Out Redefined: The Role of Reserve Accumulation." NBER Working Paper No. 19652. Cambridge, MA: National Bureau of Economic Research.

Reinhart, C. and V. Reinhart, 2008. "Capital Inflows and Reserve Accumulation: The Recent Evidence." NBER Working paper 13842. Cambridge, MA: National Bureau of Economic Research.

Reinhart, C. and K. Rogoff, J. 2004. " "Serial Default and the 'Paradox' of Rich to Poor Capital Flows." American Economic Review, 94, 53-58.

Reinhart, C. and K. Rogoff, J. 2008. "This Time is Different: A Panoramic View of Eight Centuries of Financial Crises." NBER Working Paper 13882. Cambridge, MA: National Bureau of Economic Research.

Rodrik, D. 2006. "The Social Cost of Foreign Exchange Reserves." International Economic Journal, 20(3), 253-266.

Song, Z., K. Storesletten and F. Zilibotti, 2011. "Growing Like China." American Economic Review, 101, 196-233.

Tornell, A. and A. Velasco, 1992. "Why Does Capital Flow from Poor to Rich Countries? The Tragedy of the Commons and Economic Growth." Journal of Political Economy, 100, 1208-1231.

Tornell, A. and P. R. Lane, 1999. "The Voracity Effect." American Economic Review, $89,22-46$.

Tornell, A. and P. R. Lane, 1998. "Are Windfalls a Curse? A Non-Representative Agent Model of the Current Account." Journal of International Economics, 44, 83-112.

Welsch, R. E., and E. Kuh. 1977. "Linear Regression Diagnostics." Technical Report 923-77. Cambridge, MA: Massachusetts Institute of Technology. 
TABLE 1. Net Capital Flows and Growth in Developing Countries, 1970-2007

Raw World Sample

\begin{tabular}{|c|c|c|c|c|c|c|c|c|c|c|c|c|c|c|}
\hline & (1) & (2) & (3) & (4) & (5) & (6) & (7) & (8) & (9) & (10) & (11) & (12) & (13) & (14) \\
\hline & & \multicolumn{13}{|c|}{ Measures of Flows } \\
\hline & $\begin{array}{l}\text { GDP per } \\
\text { capita } \\
\text { growth }\end{array}$ & $\begin{array}{l}\text { Net capital } \\
\text { flows } \\
\text { (-CA/GDP) }\end{array}$ & $\begin{array}{l}\text { Net capital } \\
\text { flows } \\
\text { (-NFA/GDP) }\end{array}$ & $\begin{array}{l}\text { Net capital } \\
\text { flows } \\
\text { (-NFA/GDP) }\end{array}$ & $\begin{array}{c}\text { Net FDI } \\
\text { +Portfolio } \\
\text { Flows/GDP }\end{array}$ & $\begin{array}{c}\text { Net FDI } \\
+ \text { +Portfolio } \\
\text { Flows/GDP }\end{array}$ & $\begin{array}{l}\text { Net Debt } \\
\text { Flows/GDP }\end{array}$ & $\begin{array}{l}\text { Net Debt } \\
\text { Flows/GDP }\end{array}$ & $\begin{array}{l}\text { Net Total } \\
\text { Aid Receipts } \\
\text { /GDP }\end{array}$ & $\begin{array}{c}\text { Reserve } \\
\text { \& Related } \\
\text { Assets } \\
\text { Accumulation } \\
\text { /GDP }\end{array}$ & $\begin{array}{l}\text { Reserve } \\
\text { Accumulation } \\
\text { /GDP }\end{array}$ & $\begin{array}{l}\text { Net E\&O } \\
\text { /GDP }\end{array}$ & $\begin{array}{l}\text { Net PPG } \\
\text { Debt Flows } \\
\text {-Reserve } \\
\text { Accumulation } \\
\text { /GDP }\end{array}$ & $\begin{array}{c}\text { Net Grants } \\
\text { + Net PPG } \\
\text { Debt Flows } \\
\text { from Official } \\
\text { Creditors } \\
\text { +IMF Credit } \\
\text { - Reserve } \\
\text { Accumulation } \\
\text { /GDP }\end{array}$ \\
\hline Data Source & WB & IMF,WB & IMF,WB & LM & IMF,WB & LM & IMF,WB & LM & $\mathrm{OECD}, \mathrm{WB}$ & IMF,WB & IMF,WB & IMF,WB & wB & IMF,OECD,WB \\
\hline \multicolumn{15}{|c|}{33 Low-Growth Non-OECD Developing Countries } \\
\hline 1970-2007 & -0.14 & 5.36 & 0.34 & 1.69 & 1.09 & 1.74 & -0.03 & 0.88 & 11.53 & -3.19 & 0.49 & -0.77 & 3.24 & 14.27 \\
\hline $1970-1979$ & 0.39 & 0.97 & 3.59 & 1.82 & 0.76 & 1.14 & 1.42 & 2.30 & 8.16 & 0.07 & 1.33 & -0.61 & 5.14 & 9.71 \\
\hline 1980-1989 & -1.33 & 6.64 & -0.32 & 3.60 & 0.31 & 0.21 & 1.47 & 3.78 & 13.52 & -3.99 & 0.02 & -0.75 & 7.54 & 17.64 \\
\hline $1990-1999$ & -0.14 & 5.85 & -1.56 & 2.59 & 1.75 & 2.13 & -0.45 & 0.91 & 13.63 & -4.01 & 0.09 & -1.50 & 1.73 & 13.87 \\
\hline $2000-2007$ & 0.94 & 5.50 & 1.40 & -1.34 & 2.50 & 3.17 & -2.19 & -2.69 & 9.90 & -2.29 & 1.91 & 0.27 & -2.21 & 10.93 \\
\hline $1990-2007$ & 0.47 & 5.58 & 1.65 & 0.85 & 1.91 & 2.58 & -1.39 & -0.68 & 11.62 & -3.32 & 0.65 & -0.84 & 0.02 & 12.62 \\
\hline $1980-2007$ & -0.25 & 5.69 & 0.31 & 1.68 & 1.13 & 1.87 & -0.21 & 0.66 & 12.70 & -3.52 & 0.41 & -0.80 & 2.95 & 14.53 \\
\hline \multicolumn{15}{|c|}{67 Medium-Growth Non-OECD Developing Countries } \\
\hline $1970-2007$ & 1.96 & 3.48 & 1.79 & 2.79 & 1.99 & 2.68 & 0.38 & 1.77 & 5.26 & -0.41 & 1.61 & -0.05 & 0.81 & 5.08 \\
\hline $1970-1979$ & 3.11 & 3.72 & & 4.18 & 1.40 & 1.87 & 3.53 & 3.80 & 4.39 & 0.96 & 1.67 & -0.26 & 3.30 & 4.74 \\
\hline $1980-1989$ & 0.57 & 4.19 & -1.80 & 4.53 & 0.95 & 0.75 & 1.09 & 4.00 & 5.43 & -2.33 & 0.46 & -0.22 & 4.16 & 7.61 \\
\hline $1990-1999$ & 1.17 & 4.32 & 3.52 & 2.53 & 1.88 & 2.35 & 0.16 & 1.52 & 6.36 & -1.16 & 1.55 & 0.20 & -0.06 & 5.46 \\
\hline $2000-2007$ & 2.89 & 1.87 & 3.69 & 0.66 & 3.45 & 4.77 & -1.12 & -1.40 & 3.60 & 1.33 & 2.33 & -0.35 & -1.72 & 2.00 \\
\hline $1990-2007$ & 2.14 & 3.13 & 4.07 & 1.71 & 2.72 & 3.52 & -0.41 & 0.19 & 4.85 & 0.17 & 1.96 & -0.09 & -0.91 & 3.74 \\
\hline $1980-2007$ & 1.67 & 3.44 & 1.79 & 2.56 & 2.06 & 2.79 & 0.04 & 1.35 & 5.30 & -0.58 & 1.55 & -0.03 & 0.61 & 5.01 \\
\hline \multicolumn{15}{|c|}{34 High-Growth Non-OECD Developing Countries } \\
\hline $1970-2007$ & 5.16 & 5.42 & 0.81 & 4.67 & 4.05 & 4.57 & 1.93 & 2.44 & 4.44 & 1.57 & 2.30 & -0.02 & 0.48 & 3.07 \\
\hline $1970-1979$ & 5.81 & 4.72 & & 2.57 & 2.09 & 2.71 & 4.45 & 3.51 & 6.46 & 2.57 & 3.38 & 0.66 & 1.33 & 4.10 \\
\hline $1980-1989$ & 4.40 & 6.37 & -1.33 & 4.69 & 2.85 & 2.72 & 3.08 & 3.76 & 6.78 & 0.61 & 1.80 & 0.52 & 3.23 & 8.52 \\
\hline 1990-1999 & 3.60 & 5.69 & 3.07 & 4.88 & 4.29 & 4.48 & 1.11 & 2.08 & 3.85 & 0.69 & 1.87 & -0.20 & 0.57 & 3.47 \\
\hline $2000-2007$ & 4.23 & 4.85 & -2.52 & 3.93 & 4.99 & 5.87 & 0.60 & 0.84 & 2.03 & 2.25 & 2.54 & -0.09 & -0.84 & 0.36 \\
\hline $1990-2007$ & 4.11 & 5.08 & -2.63 & 4.32 & 4.58 & 5.10 & 0.77 & 1.50 & 2.80 & 1.62 & 2.28 & -0.14 & -0.28 & 1.69 \\
\hline $1980-2007$ & 4.92 & 5.32 & 0.81 & 4.62 & 4.14 & 4.61 & 1.65 & 2.21 & 4.00 & 1.50 & 2.22 & -0.05 & 0.40 & 2.95 \\
\hline \multicolumn{15}{|c|}{22 Advanced OECD Countries (excluding Luxembourg) } \\
\hline $1970-2007$ & 2.25 & 0.48 & 1.81 & 1.28 & -0.32 & 0.27 & 1.11 & 1.47 & 0.00 & 0.15 & 0.34 & -0.06 & . & . \\
\hline $1970-1979$ & 3.08 & 1.78 & 1.20 & 1.59 & 0.26 & 0.34 & 1.90 & 1.97 & 0.00 & 0.22 & 0.53 & 0.00 & . & \\
\hline $1980-1989$ & 2.06 & 1.45 & 0.36 & 1.51 & 0.02 & 0.22 & 1.52 & 1.83 & 0.00 & -0.06 & 0.45 & 0.20 & . & \\
\hline $1990-1999$ & 1.77 & 0.07 & 1.59 & 0.62 & -0.22 & 1.03 & 0.59 & -0.13 & 0.00 & 0.34 & 0.35 & -0.17 & . & \\
\hline $2000-2007$ & 1.05 & -0.03 & 1.33 & 1.89 & -0.64 & -0.64 & 0.40 & 2.81 & 0.00 & -0.73 & 0.56 & -0.53 & . & \\
\hline 1990-2007 & 1.35 & 0.01 & 1.57 & 1.19 & -0.40 & 0.29 & 0.42 & 1.18 & 0.00 & -0.25 & 0.45 & -0.36 & . & \\
\hline $1980-2007$ & 1.98 & 0.35 & 1.82 & 1.30 & -0.42 & 0.26 & 1.06 & 1.41 & 0.00 & 0.12 & 0.30 & -0.10 & . & \\
\hline
\end{tabular}

Notes: The statistics shown are based on "Raw World" sample of 22 advanced OECD countries and 134 nonOECD countries. All flows are expressed as percent of GDP. The data comes from several sources; the IMF's IFS database ("IMF"); Lane and Milesi-Ferretti Mark II dataset ("LM"); OECD DAC database ("OECD"), and World Bank GDF dataset ("WB"). The countries are divided into groups according to the average 1970-2007 growth rate of the real GDP per capita in 2000 U.S. dollars. Low-Growth Countries are the ones with growth rates below 25 th percent quartile ( 0.94 percent); High-Growth Countries are economies with growth rates above 75 th percent quartile (3.19 percent); the rest of countries are assigned to the Medium-Growth Countries group. "Net capital flows (-CA/GDP)" represents the average of the annual current account balance with the sign reversed in current U.S. dollars, normalized by GDP in current U.S. dollars. "Net capital flows (-NFA/GDP)" (IMF,WB data) represents the average of the annual changes in stocks of total liabilities minus total assets from the IMF's International Investment Position statistics in current U.S. dollars, normalized by GDP in current U.S. dollars. "Net capital flows (-NFA/GDP)" (LM data) represents the average of the annual changes in Net Foreign Assets (Net External Position) with the sign reversed as percentage of GDP; these flows include valuation effects. Details of other variables are in Appendix A and the countries included are listed in Table 2. 
TABLE 2. Net Capital Flows and Growth, by Country, 1980-2007

Out of Raw World Sample

\begin{tabular}{|c|c|c|c|c|c|c|c|c|c|c|c|c|c|c|c|c|}
\hline & & & & & & (1) & (2) & (3) & (4) & (5) & (6) & (7) & (8) & (9) & (10) & (11) \\
\hline $\begin{array}{c}\text { Raw } \\
\text { Deve } \\
\text {-loping } \\
\text { Sample }\end{array}$ & $\begin{array}{c}\text { Deve } \\
\text {-loping } \\
\text { Sample }\end{array}$ & $\begin{array}{r}\text { Bench } \\
\text { mark } \\
\text { Sampl }\end{array}$ & $\begin{array}{r}\mathrm{PW} \\
\text { Sam }\end{array}$ & & $\begin{array}{l}1970 \\
\text { Sample }\end{array}$ & $\begin{array}{l}\text { GDP per } \\
\text { capita } \\
\text { growth }\end{array}$ & $\begin{array}{l}\text { Net capital } \\
\text { flows/GDP } \\
\text { (-CA/GDP) }\end{array}$ & $\begin{array}{l}\text { Aid-adjusted } \\
\text { net capital } \\
\text { flows/GDP }\end{array}$ & $\begin{array}{c}\text { Net FDI } \\
+ \text { +Portfolio } \\
\text { Flows/GDP }\end{array}$ & $\begin{array}{c}\text { Net Debt } \\
\text { Flows/GDP }\end{array}$ & $\begin{array}{l}\text { Net total } \\
\text { Aid Receipts } \\
\text { /GDP }\end{array}$ & $\begin{array}{c}\text { Reserve } \\
\text { \& Related } \\
\text { Assets } \\
\text { Accumulation } \\
\text { /GDP }\end{array}$ & $\begin{array}{l}\text { Reserve } \\
\text { Accumulation } \\
\text { /GDP }\end{array}$ & $\begin{array}{l}\text { Net E\&O } \\
\text { /GDP }\end{array}$ & $\begin{array}{c}\text { Net PPG } \\
\text { Debt Flows } \\
\text {-Reserve } \\
\text { Accumulation } \\
\text { /GDP }\end{array}$ & $\begin{array}{c}\text { Net Grants } \\
\text { + Net PPG } \\
\text { Debt Flows } \\
\text { from Official } \\
\text { Creditors } \\
\text { +IMF Credit } \\
\text {-Reserve } \\
\text { Accumulation } \\
\text { /GDP }\end{array}$ \\
\hline
\end{tabular}

\begin{tabular}{|c|c|c|c|c|c|c|c|c|c|c|c|c|c|c|c|c|c|}
\hline \multicolumn{18}{|c|}{ Africa } \\
\hline CIV & Cote d'Ivoire & $\mathrm{x}$ & $\mathrm{x}$ & $\mathrm{x}$ & $\mathrm{x}$ & $\mathrm{x}$ & -2.1 & 4.9 & 0.5 & 1.3 & -2.5 & 4.4 & -6.1 & 0.5 & -0.5 & 2.3 & 5.3 \\
\hline DJI & Djibouti & $\begin{array}{l}\lambda \\
\mathrm{x}\end{array}$ & $\begin{array}{l}\hat{x} \\
\mathrm{x}\end{array}$ & $\lambda$ & $\lambda$ & $\lambda$ & $\begin{array}{l}-2.1 \\
-1.9\end{array}$ & $\begin{array}{l}4.9 \\
-0.2\end{array}$ & -17.1 & 3.2 & -4.4 & $\begin{array}{l}4.4 \\
19.4\end{array}$ & $\begin{array}{l}-0.1 \\
-2.8\end{array}$ & 0.2 & -4.5 & 4.2 & 18.3 \\
\hline NER & Niger & $\mathrm{x}$ & $\mathrm{x}$ & $\mathrm{x}$ & $\mathrm{x}$ & & -1.5 & 7.5 & -7.1 & 0.4 & 1.4 & 14.6 & -0.1 & 0.3 & 1.9 & 1.4 & 15.2 \\
\hline $\mathrm{CAF}$ & Centr. Afr. Rep. & $\mathrm{x}$ & $\mathrm{x}$ & $\mathrm{x}$ & & & -1.3 & 4.4 & -10.2 & 0.1 & 3.0 & 12.2 & -1.3 & 0.8 & 0.0 & 3.5 & 14.5 \\
\hline MDG & Madagascar & $\mathrm{x}$ & $\mathrm{x}$ & $\mathrm{x}$ & $\mathrm{x}$ & $\mathrm{x}$ & -1.2 & 8.0 & -3.3 & 0.3 & -0.8 & 11.4 & -6.5 & 0.6 & 0.3 & 2.8 & 11.6 \\
\hline ZWE & Zimbabwe & $\hat{x}$ & $\mathrm{x}$ & $\mathrm{x}$ & & & -0.9 & 2.9 & -1.6 & 0.1 & 2.7 & 4.5 & 0.1 & 0.4 & 0.4 & 23 & 59 \\
\hline GAB & Gabon & $\mathrm{x}$ & $\mathrm{x}$ & $\mathrm{x}$ & $\dot{x}$ & $\mathrm{x}$ & -0.7 & -3.4 & -5.1 & 0.1 & -4.8 & 1.6 & -2.2 & 0.3 & -0.9 & 1.8 & 4.3 \\
\hline $\mathrm{ZMB}$ & Zambia & $\mathrm{x}$ & $\mathrm{x}$ & & & $\mathrm{x}$ & -0.7 & 13.0 & -2.0 & 2.7 & -0.9 & 17.9 & -8.5 & 0.3 & -0.7 & 3.0 & 17.1 \\
\hline BDI & Burundi & $\mathrm{x}$ & $\mathrm{x}$ & $\mathrm{x}$ & . & . & -0.6 & 9.2 & -12.6 & 0.1 & 2.0 & 20.2 & -8.1 & 1.3 & -1.6 & 3.1 & 21.5 \\
\hline $\mathrm{COM}$ & Comoros * & $\mathrm{x}$ & $\mathrm{x}$ & $\mathrm{x}$ & & & -0.6 & 7.5 & -20.4 & 0.5 & 9.7 & 20.6 & -0.0 & 1.4 & -2.7 & 6.1 & 26.2 \\
\hline TGO & Togo & $\mathrm{x}$ & $\mathrm{x}$ & $\mathrm{x}$ & $\mathrm{x}$ & $\mathrm{x}$ & -0.5 & 7.6 & -1.8 & 2.0 & 1.8 & 9.4 & -3.1 & 1.2 & 0.0 & 0.1 & 9.2 \\
\hline SLE & Sierra Leone & $\mathrm{x}$ & $\mathrm{x}$ & $\mathrm{x}$ & & & -0.1 & 7.5 & -11.6 & 0.2 & -0.4 & 19.2 & -4.8 & 0.9 & 1.4 & 2.2 & 18.8 \\
\hline CMR & Cameroon & $\mathrm{x}$ & $\mathrm{x}$ & $\mathrm{x}$ & $\mathrm{x}$ & $\mathrm{x}$ & -0.0 & 3.5 & -0.9 & 1.0 & -0.2 & 4.4 & -2.4 & 0.5 & -0.2 & 0.7 & 4.6 \\
\hline MWI & Malawi & $\mathrm{x}$ & $\mathrm{x}$ & $\mathrm{x}$ & $\mathrm{x}$ & . & 0.1 & 9.1 & -12.0 & 0.9 & 3.7 & 21.2 & -0.7 & -0.1 & 0.4 & 3.1 & 22.9 \\
\hline GNB & Guinea-Bissau & $\mathrm{x}$ & & & & . & 0.1 & 26.6 & -14.9 & 0.7 & 2.3 & 41.3 & -12.8 & 1.8 & -2.7 & 15.8 & 46.8 \\
\hline GMB & Gambia & $\mathrm{x}$ & $\mathrm{x}$ & $\mathrm{x}$ & & & 0.1 & 3.7 & -16.4 & 1.3 & 0.6 & 17.7 & -1.9 & 1.5 & -1.5 & 5.2 & 21.1 \\
\hline SEN & Senegal & $\mathrm{x}$ & $\mathrm{x}$ & $\mathrm{x}$ & $\mathrm{x}$ & $\mathrm{x}$ & 0.2 & 7.7 & -3.2 & 0.8 & 0.9 & 10.9 & -3.6 & 0.6 & -0.0 & 1.3 & 10.8 \\
\hline KEN & Kenya & $\mathrm{x}$ & $\mathrm{x}$ & $\mathrm{x}$ & $\mathrm{x}$ & $\mathrm{x}$ & 0.3 & 5.7 & -1.1 & 0.4 & 2.3 & 6.8 & 0.3 & 1.1 & 2.7 & 0.9 & 6.2 \\
\hline $\mathrm{ZAF}$ & South Africa & $\mathrm{x}$ & $\mathrm{x}$ & $\mathrm{x}$ & $\mathrm{x}$ & & 0.4 & 0.5 & 0.3 & 0.8 & -0.0 & 0.2 & 0.5 & 0.5 & 0.3 & -0.5 & -0.6 \\
\hline DZA & Algeria & $\mathrm{x}$ & $\mathrm{x}$ & $\mathrm{x}$ & . & $\mathrm{x}$ & 0.4 & -4.6 & -4.9 & 0.3 & -1.3 & 0.4 & 3.3 & 3.5 & -0.3 & -3.6 & -3.6 \\
\hline MRT & Mauritania & $\mathrm{x}$ & $\mathrm{x}$ & 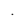 & . & & 0.5 & 10.6 & -11.3 & 0.7 & 6.9 & 19.7 & -4.0 & -0.1 & -1.1 & 9.1 & 24.3 \\
\hline NAM & Namibia & $\mathrm{x}$ & & & & & 0.6 & -3.6 & -7.8 & -1.5 & -7.0 & 2.9 & -2.2 & 1.2 & 1.4 & & \\
\hline MLI & Mali & $\mathrm{x}$ & $\mathrm{x}$ & $\mathrm{x}$ & $\mathrm{x}$ & $\mathrm{x}$ & 0.6 & 9.1 & -8.2 & 1.4 & 1.9 & 17.3 & -2.1 & 1.2 & -0.2 & 2.4 & 16.5 \\
\hline NGA & Nigeria & $\mathrm{x}$ & $\mathrm{x}$ & $\mathrm{x}$ & $\mathrm{x}$ & $\mathrm{x}$ & 0.7 & -4.0 & -5.0 & 2.9 & -11.0 & 1.0 & -4.4 & 1.9 & -0.6 & 0.9 & 1.7 \\
\hline IRN & Iran & $\mathrm{x}$ & $\mathrm{x}$ & $\mathrm{x}$ & $\mathrm{x}$ & & 0.9 & -1.0 & -1.1 & 0.0 & -1.1 & 0.1 & -0.3 & -0.3 & -0.3 & 1.1 & 0.9 \\
\hline BEN & Benin & $\mathrm{x}$ & $\mathrm{x}$ & $\mathrm{x}$ & $\mathrm{x}$ & & 0.9 & 7.4 & -3.1 & 1.4 & -2.1 & 10.5 & -5.6 & 1.3 & 0.4 & 0.7 & 9.7 \\
\hline GHA & Ghana & $\mathrm{x}$ & $\mathrm{x}$ & $\mathrm{x}$ & $\mathrm{x}$ & $\mathrm{x}$ & 1.0 & 4.8 & -3.9 & 1.5 & 3.8 & 8.7 & 0.6 & 1.1 & -0.2 & 1.4 & 7.8 \\
\hline ETH & Ethiopia & $\mathrm{x}$ & $\mathrm{x}$ & $\mathrm{x}$ & $\mathrm{x}$ & . & 1.1 & 2.6 & -7.2 & 0.4 & 0.9 & 9.8 & -2.4 & -0.4 & -1.0 & 1.6 & 10.3 \\
\hline COG & Congo Rep. Of & $\mathrm{x}$ & $\mathrm{x}$ & $\mathrm{X}$ & $\mathrm{x}$ & & 1.1 & 10.4 & 4.3 & 4.6 & -9.4 & 6.1 & -14.3 & 1.1 & 0.6 & 5.8 & 8.6 \\
\hline YEM & Yemen & $\hat{x}$ & $\mathrm{x}$ & $\hat{x}$ & & & 1.3 & 1.0 & -2.9 & 0.9 & -5.0 & 3.9 & -0.8 & $\begin{array}{l}1.1 \\
3.7\end{array}$ & -0.1 & -2.9 & $\begin{array}{l}0.0 \\
1.0\end{array}$ \\
\hline JOR & Jordan & $\mathrm{x}$ & $\mathrm{x}$ & $\mathrm{x}$ & $\mathrm{x}$ & & 1.4 & 3.5 & -7.7 & 3.6 & 3.6 & 11.1 & $\begin{array}{l}-0.0 \\
3.9\end{array}$ & 5.8 & -0.2 & -1.6 & 7.6 \\
\hline SYR & Syrian & $\hat{x}$ & $\hat{x}$ & $\mathrm{x}$ & $\mathrm{x}$ & & 1.4 & -1.2 & -4.6 & 0.7 & -0.1 & 3.4 & 1.6 & 1.6 & -0.3 & 0.8 & 3.7 \\
\hline LSO & Lesotho & $\hat{x}$ & $\mathrm{x}$ & & & & 1.5 & 2.4 & -14.6 & 2.7 & -4.6 & 16.9 & $\begin{array}{l}1.0 \\
5.6\end{array}$ & $\begin{array}{l}1.0 \\
5.8\end{array}$ & 3.0 & -1.5 & 12.2 \\
\hline RWA & Rwanda & $\hat{x}$ & $\mathrm{x}$ & $\dot{x}$ & $\mathrm{x}$ & $x$ & 1.5 & 3.9 & -16.2 & 0.6 & -0.1 & 20.2 & -0.4 & 1.0 & 0.5 & 0.7 & 19.6 \\
\hline TZA & Tanzania & $\hat{x}$ & $\mathrm{x}$ & $\hat{x}$ & $\mathrm{x}$ & & 1.8 & 10.5 & -6.0 & 2.4 & 0.8 & 16.4 & -1.4 & 1.7 & -0.5 & -1.3 & 13.8 \\
\hline $\begin{array}{l}\text { IZA } \\
\text { MAR }\end{array}$ & $\begin{array}{l}\text { lanzzanla } \\
\text { Morocco }\end{array}$ & $\begin{array}{l}x \\
x\end{array}$ & $\begin{array}{l}x \\
x\end{array}$ & $\begin{array}{l}x \\
x\end{array}$ & $\begin{array}{l}x \\
x\end{array}$ & $\dot{x}$ & $\begin{array}{l}1.8 \\
1.9\end{array}$ & $\begin{array}{l}10.5 \\
1.9\end{array}$ & $\begin{array}{l}-6.0 \\
-0.9\end{array}$ & $\begin{array}{l}2.4 \\
1.0\end{array}$ & $\begin{array}{l}0.8 \\
0.8\end{array}$ & $\begin{array}{l}16.4 \\
2.8\end{array}$ & $\begin{array}{c}-1.4 \\
0.0\end{array}$ & $\begin{array}{l}1.7 \\
1.6\end{array}$ & $\begin{array}{c}-0.3 \\
0.1\end{array}$ & $\begin{array}{c}-1.3 \\
0.8\end{array}$ & $\begin{array}{l}13.8 \\
2.4\end{array}$ \\
\hline $\mathrm{BFA}$ & Burkina Faso & $\hat{x}$ & $\mathrm{x}$ & $\mathrm{x}$ & ?. & & 2.0 & 5.8 & -7.4 & 0.4 & 0.9 & 13.7 & -1.9 & 0.8 & 0.1 & 0.8 & 12.4 \\
\hline SDN & Sudan & $\hat{x}$ & $\mathrm{x}$ & $\mathrm{x}$ & . & $\dot{x}$ & 2.1 & 4.8 & -0.2 & 2.4 & 0.8 & 5.0 & -1.1 & 0.5 & 0.9 & 1.9 & 5.8 \\
\hline MOZ & Mozambique & $\hat{x}$ & $\mathrm{x}$ & $\mathrm{x}$ & $\mathrm{x}$ & . & 2.1 & 14.4 & -13.0 & 2.3 & 1.2 & 27.4 & -13.2 & -0.0 & -4.1 & 2.9 & 31.7 \\
\hline SYC & Seychelles * & $\hat{x}$ & $\hat{x}$ & $\hat{x}$ & $\hat{A}$ & & 2.2 & $\begin{array}{l}11.4 \\
11.3\end{array}$ & 5.2 & 5.5 & 2.9 & 6.1 & -2.7 & 0.3 & -0.5 & 4.3 & 6.5 \\
\hline UGA & Uganda & $\mathrm{x}$ & $\mathrm{x}$ & $\mathrm{x}$ & $\mathrm{x}$ & & 2.4 & 4.2 & -7.8 & 1.8 & 1.2 & 12.1 & -0.5 & 1.2 & -0.7 & 0.7 & 11.5 \\
\hline GIN & Guinea & $\mathrm{x}$ & $\mathrm{x}$ & $\mathrm{x}$ & & & 2.4 & 6.0 & -3.4 & 2.0 & -0.0 & 9.4 & -2.9 & -0.3 & 1.0 & 3.2 & 10.1 \\
\hline AGO & Angola & $\mathrm{x}$ & $\mathrm{x}$ & $\mathrm{x}$ & $\mathrm{x}$ & & 2.5 & 1.0 & -2.8 & 7.2 & -8.7 & 3.8 & -4.9 & 1.6 & -2.5 & -0.5 & 2.6 \\
\hline LBY & Libya & $\mathrm{x}$ & & & . & & 2.6 & -11.3 & -11.3 & -0.3 & -1.7 & 0.0 & 10.1 & 10.1 & 0.7 & & \\
\hline TCD & Chad & $\mathrm{x}$ & $\mathrm{x}$ & $\mathrm{x}$ & & $\mathrm{x}$ & 2.6 & 2.0 & -11.6 & 0.7 & 1.4 & 12.2 & -0.6 & 0.1 & -0.7 & 1.6 & 13.1 \\
\hline TUN & Tunisia & $\mathrm{x}$ & $\mathrm{x}$ & $\mathrm{x}$ & $\mathrm{x}$ & $\mathrm{x}$ & 2.6 & 3.9 & 2.1 & 2.6 & 2.0 & 1.8 & 1.3 & 1.3 & 0.5 & 1.4 & 2.0 \\
\hline EGY & Egypt & $\mathrm{x}$ & $\mathrm{x}$ & $\mathrm{x}$ & $\mathrm{x}$ & $\mathrm{x}$ & 2.9 & 0.7 & -3.7 & 2.3 & -2.9 & 4.4 & -1.1 & 2.0 & 0.2 & 0.7 & 3.8 \\
\hline swZ & Swaziland * & $\mathrm{x}$ & $\mathrm{x}$ & $\mathrm{x}$ & & $\mathrm{x}$ & 3.4 & 3.0 & -0.9 & 3.2 & -2.4 & 3.9 & 0.1 & 0.1 & 2.4 & 0.8 & 4.4 \\
\hline MUS & Mauritius & $\mathrm{x}$ & $\mathrm{x}$ & $\mathrm{x}$ & $\mathrm{x}$ & . & 3.6 & 2.2 & 0.5 & 0.7 & 0.7 & 1.8 & 1.6 & 2.3 & 2.5 & -1.1 & 0.2 \\
\hline $\mathrm{CPV}$ & Cape Verde* & $\mathrm{x}$ & $\mathrm{x}$ & $\mathrm{x}$ & & : & 4.3 & 7.3 & -20.9 & 3.1 & 5.7 & 28.2 & 1.8 & 1.3 & -1.3 & 3.1 & 26.4 \\
\hline BWA & Botswana & $\hat{x}$ & . & . & $\mathrm{x}$ & : & 5.0 & -5.5 & -9.4 & 1.9 & -0.7 & 3.9 & 11.1 & 11.3 & 3.8 & -10.2 & -6.7 \\
\hline & $\mathrm{N}$ & 51 & 47 & 43 & 29 & 19 & 51 & 51 & 51 & 51 & 51 & 51 & 51 & 51 & 51 & 49 & 49 \\
\hline & mean & & & & & & 1.0 & 4.5 & -6.4 & 1.5 & -0.1 & 10.6 & -1.8 & 1.5 & -0.1 & 1.7 & 11.0 \\
\hline & sd & & & & & & 1.6 & 5.9 & 6.2 & 1.5 & 3.8 & 8.7 & 4.7 & 2.3 & 1.6 & 3.5 & 9.9 \\
\hline & $\min$ & & & & & & -2.1 & -11.3 & -20.9 & -1.5 & -11.0 & 0.0 & -14.3 & -0.4 & -4.5 & -10.2 & -6.7 \\
\hline & $\max$ & & & & & & 5.0 & 26.6 & 5.2 & 7.2 & 9.7 & 41.3 & 11.1 & 11.3 & 3.8 & 15.8 & 46.8 \\
\hline
\end{tabular}

Asia

\begin{tabular}{|c|c|c|c|c|c|c|c|c|c|c|c|c|c|c|c|c|c|}
\hline SAU & Saudi Arabia & $\mathrm{x}$ & . & & & & -1.7 & -1.1 & -1.1 & 1.2 & 0.6 & 0.0 & 2.0 & 2.0 & -0.7 & . & \\
\hline KWT & Kuwait & $\mathrm{x}$ & . & . & . & & -1.5 & -16.1 & -16.2 & -0.6 & -4.6 & 0.0 & 1.4 & 1.4 & -10.1 & . & \\
\hline KIR & Kiribati & $\mathrm{x}$ & & & & & -1.1 & 6.8 & -46.9 & 0.2 & -14.6 & 39.7 & -16.6 & -13.0 & -12.2 & & \\
\hline PNG & Papua New Gunea & $\mathrm{x}$ & $\mathrm{x}$ & $\mathrm{x}$ & $\mathrm{x}$ & & -0.0 & 2.3 & -6.6 & 3.4 & -2.3 & 8.9 & -0.5 & 1.2 & 1.3 & 0.1 & 8.4 \\
\hline SLB & Solomon Isl. * & $\mathrm{x}$ & $\mathrm{x}$ & $\mathrm{x}$ & & & 0.2 & 8.6 & -8.9 & 2.3 & 0.7 & 17.5 & -2.5 & -0.2 & 2.3 & 2.1 & 17.8 \\
\hline PHL & Philippines & $\mathrm{x}$ & $\mathrm{x}$ & $\mathrm{x}$ & $\mathrm{x}$ & $\mathrm{x}$ & 0.7 & 2.2 & 0.8 & 1.4 & 2.3 & 1.4 & 1.0 & 1.1 & -0.6 & 17 & 1.4 \\
\hline VUT & Vanuatu & $\mathrm{x}$ & $\mathrm{x}$ & & & 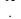 & 0.7 & 8.7 & -9.8 & 7.9 & -3.4 & 19.7 & -1.2 & 1.7 & -3.3 & -0.2 & 17.0 \\
\hline FJI & $\mathrm{Fiji}^{*}$ * & $\mathrm{x}$ & $\mathrm{x}$ & $\mathrm{x}$ & $\dot{x}$ & & 0.8 & 4.2 & 1.5 & 2.8 & 0.6 & 2.7 & 0.8 & 0.7 & 0.5 & -0.2 & 2.3 \\
\hline BHR & Bahrain & $\mathrm{x}$ & & & . & & 0.8 & -1.6 & -3.8 & 0.3 & -2.8 & 2.1 & 1.6 & 1.6 & 1.1 & & \\
\hline TON & Tonga * & $\mathrm{x}$ & $\mathrm{x}$ & $\mathrm{x}$ & & & 1.8 & 2.8 & -16.6 & 1.2 & 2.7 & 18.1 & 0.1 & 0.1 & -2.5 & 3.7 & 19.1 \\
\hline NPL & Nepal & $\mathrm{x}$ & $\mathrm{x}$ & $\mathrm{x}$ & $\mathrm{x}$ & $\mathrm{x}$ & 1.8 & 4.3 & -4.5 & 0.1 & 2.8 & 8.7 & -0.0 & 1.4 & 1.2 & 1.7 & 7.8 \\
\hline ISR & Israel & $\mathrm{x}$ & & & $\mathrm{x}$ & & 2.0 & 1.8 & -0.5 & 0.8 & 0.3 & 2.3 & -0.1 & 1.0 & -0.4 & & \\
\hline MNG & Mongolia & $\mathrm{x}$ & $\mathrm{x}$ & $\mathrm{x}$ & & & 2.1 & 14.6 & 5.7 & 1.7 & 11.9 & 8.9 & -1.0 & 1.3 & -0.6 & 3.4 & 12.9 \\
\hline wSM & Samoa * & $\mathrm{x}$ & $\mathrm{x}$ & $\mathrm{x}$ & & & 2.1 & 3.7 & -19.7 & 0.2 & 2.1 & 21.9 & 2.6 & 2.8 & 1.8 & 1.1 & 20.7 \\
\hline BGD & Bangladesh & $\mathrm{x}$ & $\mathrm{x}$ & $\mathrm{x}$ & $\mathrm{x}$ & & 2.3 & 1.0 & -3.4 & 0.3 & 1.1 & 4.5 & 0.4 & 0.4 & -0.2 & 1.7 & 4.6 \\
\hline PAK & Pakistan & $\mathrm{x}$ & $\mathrm{x}$ & $\mathrm{x}$ & $\mathrm{x}$ & $\mathrm{x}$ & 2.6 & 2.6 & 0.2 & 1.1 & 1.1 & 2.3 & -0.1 & 0.7 & 0.2 & 1.2 & 2.4 \\
\hline OMN & Oman & $\mathrm{x}$ & $\mathrm{x}$ & $\mathrm{x}$ & & & 3.1 & -3.0 & -3.9 & 1.6 & -0.4 & 0.9 & 3.1 & 3.1 & -1.1 & -2.0 & -1.8 \\
\hline LKA & Sri Lanka & $\mathrm{x}$ & $\mathrm{x}$ & $\mathrm{x}$ & $\mathrm{x}$ & $\mathrm{x}$ & 3.6 & 5.3 & -0.4 & 1.1 & 3.5 & 5.6 & -0.3 & 0.8 & 0.1 & 3.0 & 5.3 \\
\hline LAO & Lao PDR & $\mathrm{x}$ & $\mathrm{x}$ & & & & 3.6 & 9.5 & -3.7 & 1.5 & 0.5 & 13.2 & -9.3 & -0.0 & -2.8 & 7.2 & 16.1 \\
\hline MYS & Malaysia & $\mathrm{x}$ & $\mathrm{x}$ & $\mathrm{x}$ & $\mathrm{x}$ & $\mathrm{x}$ & 3.7 & -1.8 & -2.2 & 3.4 & -0.5 & 0.3 & 3.8 & 3.8 & -0.7 & -2.2 & -3.2 \\
\hline IDN & Indonesia & $\mathrm{x}$ & $\mathrm{x}$ & $\mathrm{x}$ & $\mathrm{x}$ & $\mathrm{x}$ & 3.7 & 0.6 & -0.3 & 0.4 & 1.0 & 1.0 & 0.5 & 0.8 & -0.4 & 1.5 & 1.6 \\
\hline IND & India & $\mathrm{x}$ & $\mathrm{x}$ & $\mathrm{x}$ & $\mathrm{x}$ & $\mathrm{x}$ & 4.1 & 1.0 & 0.5 & 0.8 & 1.3 & 0.5 & 1.1 & 1.2 & 0.0 & -0.4 & -0.4 \\
\hline THA & Thailand & $\mathrm{x}$ & $\mathrm{x}$ & $\mathrm{x}$ & $\mathrm{x}$ & $\mathrm{x}$ & 4.5 & 1.5 & 0.9 & 2.9 & 0.2 & 0.6 & 1.7 & 2.1 & 0.2 & -1.2 & -1.2 \\
\hline SGP & Singapore & $\mathrm{x}$ & & & $\mathrm{x}$ & & 4.7 & -9.8 & -9.8 & 3.0 & -5.5 & 0.1 & 7.7 & 7.7 & 0.5 & & \\
\hline KOR & Korea Rep. Of & $\mathrm{x}$ & & & $\mathrm{x}$ & . & 5.5 & -1.0 & -1.0 & 0.1 & 1.2 & 0.0 & 1.7 & 1.7 & -0.5 & & \\
\hline KHM & Cambodia & $\mathrm{x}$ & $\mathrm{x}$ & $\mathrm{x}$ & & & 6.6 & 4.6 & -5.8 & 4.9 & -0.3 & 10.4 & 1.6 & 1.9 & -0.2 & 0.9 & 9.3 \\
\hline MDV & Maldives & $\mathrm{x}$ & & & & & 6.6 & 12.6 & 2.2 & 2.4 & 9.8 & 10.3 & 1.7 & 2.1 & 2.1 & 3.5 & 9.5 \\
\hline CHN & China & $\mathrm{x}$ & & & $\mathrm{x}$ & & 8.9 & -1.9 & -2.3 & 2.7 & -0.5 & 0.3 & 3.5 & 3.5 & -0.7 & -2.6 & -3.0 \\
\hline
\end{tabular}

Notes: Continued on the next page. 
TABLE 2 (CONT'D). Net Capital Flows and Growth, by Country, 1980-2007

Out of Raw World Sample

\begin{tabular}{|c|c|c|c|c|c|c|c|c|c|c|c|c|c|c|c|c|c|}
\hline & & & & & & & (1) & (2) & (3) & (4) & (5) & (6) & (7) & (8) & (9) & (10) & (11) \\
\hline & & $\begin{array}{c}\text { Raw } \\
\text { Deve } \\
\text {-loping } \\
\text { Sample }\end{array}$ & $\begin{array}{c}\text { Deve } \\
\text {-loping } \\
\text { Sample }\end{array}$ & $\begin{array}{c}\text { Bench- } \\
\text { mark } \\
\text { Sample }\end{array}$ & $\begin{array}{c}\text { PWT } \\
\text { Sample }\end{array}$ & $\begin{array}{l}1970 \\
\text { Sample }\end{array}$ & $\begin{array}{l}\text { GDP per } \\
\text { capita } \\
\text { growth }\end{array}$ & $\begin{array}{l}\text { Net capital } \\
\text { flows/GDP } \\
\text { (-CA/GDP) }\end{array}$ & $\begin{array}{l}\text { Aid-adjusted } \\
\text { net capital } \\
\text { flows/GDP }\end{array}$ & $\begin{array}{c}\text { Net FDI } \\
+ \text { +Portfolio } \\
\text { Flows/GDP }\end{array}$ & $\begin{array}{l}\text { Net Debt } \\
\text { Flows/GDP }\end{array}$ & $\begin{array}{l}\text { Net total } \\
\text { Aid Receipts } \\
\text { /GDP }\end{array}$ & $\begin{array}{c}\text { Reserve } \\
\text { \& Related } \\
\text { Assets } \\
\text { Accumulation } \\
\text { /GDP }\end{array}$ & $\begin{array}{l}\text { Reserve } \\
\text { Accumulation } \\
\text { /GDP }\end{array}$ & $\begin{array}{l}\text { Net E\&O } \\
/ G D P\end{array}$ & $\begin{array}{l}\text { Net PPG } \\
\text { Debt Flows } \\
\text {-Reserve } \\
\text { Accumulation } \\
\text { /GDP }\end{array}$ & $\begin{array}{c}\text { Net Grants } \\
\text { +Net PPG } \\
\text { Debt Flows } \\
\text { from Official } \\
\text { Creditors } \\
\text { +IMF Credit } \\
\text {-Reserve } \\
\text { Accumulation } \\
\text { /GDP }\end{array}$ \\
\hline \multicolumn{18}{|c|}{ Asia (continued) } \\
\hline & $\begin{array}{l}\mathrm{N} \\
\text { mean } \\
\text { sd } \\
\text { min } \\
\max \end{array}$ & 28 & 19 & 17 & 15 & 8 & $\begin{array}{c}28 \\
2.6 \\
2.5 \\
-1.7 \\
8.9\end{array}$ & $\begin{array}{c}28 \\
2.2 \\
6.2 \\
-16.1 \\
14.6\end{array}$ & $\begin{array}{c}28 \\
-5.6 \\
10.1 \\
-46.9 \\
5.7\end{array}$ & $\begin{array}{l}28 \\
1.8 \\
1.8 \\
-0.6 \\
7.9\end{array}$ & $\begin{array}{c}28 \\
0.3 \\
4.6 \\
-14.6 \\
11.9\end{array}$ & $\begin{array}{c}28 \\
7.2 \\
9.3 \\
0.0 \\
39.7\end{array}$ & $\begin{array}{c}28 \\
0.2 \\
4.3 \\
-16.6 \\
7.7\end{array}$ & $\begin{array}{c}28 \\
1.2 \\
3.2 \\
-13.0 \\
7.7\end{array}$ & $\begin{array}{c}28 \\
-0.9 \\
3.2 \\
-12.2 \\
2.3\end{array}$ & $\begin{array}{l}21 \\
1.1 \\
2.3 \\
-2.6 \\
7.2\end{array}$ & $\begin{array}{c}21 \\
7.0 \\
7.7 \\
-3.2 \\
20.7\end{array}$ \\
\hline & mean w/o China & & & & & & 2.3 & 2.4 & -5.7 & 1.7 & 0.3 & 7.5 & 0.0 & 1.1 & -0.9 & 1.3 & 7.5 \\
\hline & $\begin{array}{l}\text { sd w/o China } \\
\text { s. }\end{array}$ & & & & & & 2.2 & 6.2 & 10.3 & 1.8 & 4.7 & 9.3 & 4.3 & 3.2 & 3.2 & 2.2 & 7.6 \\
\hline & $\min w / o$ China & & & & & & -1.7 & -16.1 & -46.9 & -0.6 & -14.6 & 0.0 & -16.6 & -13.0 & -12.2 & -2.2 & -3.2 \\
\hline & $\max$ w/o China & & & & & & 6.6 & 14.6 & 5.7 & 7.9 & 11.9 & 39.7 & 7.7 & 7.7 & 2.3 & 7.2 & 20.7 \\
\hline \multicolumn{18}{|c|}{ Europe \& Central Asia } \\
\hline ROM & Romania & $\mathrm{x}$ & $\mathrm{x}$ & $\mathrm{x}$ & & & 1.4 & 4.3 & 4.3 & 2.7 & 2.5 & 0.0 & 1.6 & 1.9 & 0.5 & -1.0 & -1.4 \\
\hline HRV & Croatia & $\mathrm{x}$ & $\mathrm{x}$ & $\mathrm{x}$ & & & 1.7 & 4.4 & 4.1 & 3.5 & 5.6 & 0.3 & 2.4 & 2.7 & -2.5 & 0.6 & -1.5 \\
\hline HUN & Hungary & $\mathrm{x}$ & $\mathrm{x}$ & $\mathrm{x}$ & & & 1.7 & 4.7 & 4.7 & 3.2 & 2.7 & 0.0 & 1.3 & 1.4 & -0.2 & 0.6 & -1.2 \\
\hline ALB & Albania & $\mathrm{x}$ & $\mathrm{x}$ & $\mathrm{x}$ & & & 2.2 & 5.0 & -3.7 & 2.2 & -0.7 & 8.7 & 0.6 & 2.6 & 2.7 & 0.0 & 9.0 \\
\hline CZE & Czech Rep. & $\mathrm{x}$ & $\mathrm{x}$ & $\mathrm{x}$ & & & 2.3 & 3.6 & 3.6 & 5.2 & 1.5 & 0.0 & 3.1 & 2.9 & 0.0 & -2.3 & -3.1 \\
\hline SVK & Slovakia & $\mathrm{x}$ & $\mathrm{x}$ & $\mathrm{x}$ & & & 2.3 & 4.0 & 4.0 & 3.3 & 2.8 & 0.0 & 2.9 & 2.8 & 0.5 & -1.8 & -2.8 \\
\hline BGR & Bulgaria & $\mathrm{x}$ & $\mathrm{x}$ & $\mathrm{x}$ & & & 2.6 & 3.9 & 3.9 & 4.8 & -0.0 & 0.0 & 0.7 & 2.2 & -0.3 & -2.0 & -1.4 \\
\hline TUR & Turkey & $\mathrm{x}$ & $\mathrm{x}$ & $\mathrm{x}$ & $\mathrm{x}$ & $\mathrm{x}$ & 2.6 & 1.7 & 1.4 & 0.8 & 1.1 & 0.3 & 0.4 & 0.9 & 0.2 & 0.9 & 0.1 \\
\hline MDA & Moldova & $\mathrm{x}$ & $\mathrm{x}$ & $\mathrm{x}$ & & & 2.6 & 8.8 & 2.9 & 5.2 & -0.3 & 5.9 & -3.4 & 2.6 & 1.1 & -0.7 & 3.4 \\
\hline SVN & Slovenia & $\mathrm{x}$ & & & & & 2.9 & 0.3 & 0.1 & 0.4 & 2.3 & 0.2 & 2.0 & 2.0 & -0.3 & & \\
\hline KGZ & Kyrgyzstan & $\mathrm{x}$ & $\mathrm{x}$ & $\mathrm{x}$ & . & . & 2.9 & 10.0 & -3.2 & 3.0 & 6.6 & 13.2 & 1.1 & 3.4 & 1.8 & 3.4 & 10.0 \\
\hline MLT & Malta & $\mathrm{x}$ & & . & $\therefore$ & . & 3.0 & 2.9 & 2.0 & 5.4 & -1.5 & 0.8 & 2.1 & 2.1 & 0.3 & . & \\
\hline CYP & Cyprus & $\mathrm{x}$ & & & $\mathrm{x}$ & & 3.2 & 4.7 & 4.0 & 3.0 & 3.4 & 0.7 & 2.0 & 2.0 & 0.1 & & \\
\hline UKR & Ukraine & $\mathrm{x}$ & $\mathrm{x}$ & $\mathrm{x}$ & . & & 3.4 & -1.9 & -2.8 & 3.2 & -2.5 & 0.9 & 1.7 & 2.9 & -0.8 & -1.9 & -1.6 \\
\hline POL & Poland & $\mathrm{x}$ & $\mathrm{x}$ & $\mathrm{x}$ & & & 3.9 & 2.6 & 2.6 & 2.0 & -1.6 & 0.0 & -1.6 & 1.2 & 0.1 & -0.9 & -1.2 \\
\hline RUS & Russian Fed. & $\mathrm{x}$ & & . & . & . & 4.4 & -7.7 & -7.7 & 0.6 & -2.6 & 0.0 & 3.1 & 4.4 & -2.1 & -4.4 & -5.1 \\
\hline KAZ & Kazakhstan & $\mathrm{x}$ & $\mathrm{x}$ & & & . & 6.1 & 2.7 & 2.1 & 7.5 & 1.9 & 0.7 & 2.5 & 2.4 & -3.1 & -2.2 & -2.0 \\
\hline BLR & Belarus & $\mathrm{x}$ & $\mathrm{x}$ & & & & 6.4 & 3.5 & 3.2 & 1.8 & 2.0 & 0.4 & 0.6 & 0.9 & 0.1 & -0.8 & -0.5 \\
\hline LTU & Lithuania & $\mathrm{x}$ & $\mathrm{x}$ & $\mathrm{x}$ & & & 7.0 & 8.5 & 8.5 & 3.4 & 5.9 & 0.0 & 2.1 & 2.1 & 0.9 & 0.3 & -1.9 \\
\hline LVA & Latvia & $\mathrm{x}$ & & $\mathrm{x}$ & & & 7.8 & 9.8 & 9.8 & 4.7 & 8.0 & 0.0 & 2.5 & 2.3 & -1.1 & -1.2 & -2.0 \\
\hline EST & Estonia & $\mathrm{x}$ & & & & & 7.9 & 9.4 & 9.4 & 5.5 & 5.5 & 0.0 & 1.9 & 1.9 & -0.1 & -1.3 & -1.8 \\
\hline ARM & Armenia & $\mathrm{x}$ & & & & & 9.8 & 10.6 & 0.9 & 5.5 & 5.6 & 9.7 & 2.0 & 3.1 & 0.4 & 0.3 & 6.4 \\
\hline AZE & Azerbaijan & $\mathrm{x}$ & & & & & 10.6 & 10.5 & 7.5 & 13.0 & 1.2 & 3.1 & 2.4 & 2.9 & -0.3 & -0.9 & 0.9 \\
\hline & $\mathrm{N}$ & 23 & 15 & 14 & 2 & 1 & 23 & 23 & 23 & 23 & 23 & 23 & 23 & 23 & 23 & 20 & 20 \\
\hline & mean & & & & & & 4.3 & 4.6 & 2.7 & 3.9 & 2.2 & 1.9 & 1.5 & 2.3 & -0.1 & -0.8 & 0.1 \\
\hline & sd & & & & & & 2.7 & 4.3 & 4.2 & 2.7 & 3.0 & 3.7 & 1.5 & 0.8 & 1.3 & 1.6 & 4.0 \\
\hline & $\min$ & & & & & & 1.4 & -7.7 & -7.7 & 0.4 & -2.6 & 0.0 & -3.4 & 0.9 & -3.1 & -4.4 & -5.1 \\
\hline & $\max$ & & & & & & 10.6 & 10.6 & 9.8 & 13.0 & 8.0 & 13.2 & 3.1 & 4.4 & 2.7 & 3.4 & 10.0 \\
\hline \multicolumn{18}{|c|}{ Latin America } \\
\hline HTI & Haiti & $\mathrm{x}$ & $\mathrm{x}$ & $\mathrm{x}$ & & $\mathrm{x}$ & -1.6 & 3.8 & -6.6 & 0.5 & 0.5 & 10.4 & -1.7 & 0.8 & 1.1 & 0.4 & 9.8 \\
\hline NIC & Nicaragua & $\mathrm{x}$ & & & $\dot{x}$ & & -0.3 & 24.6 & 7.7 & 2.7 & -5.1 & 17.0 & -24.9 & 0.9 & -1.4 & 7.3 & 22.0 \\
\hline VEN & Venezuela & $\mathrm{x}$ & $\mathrm{x}$ & $\mathrm{x}$ & $\mathrm{x}$ & $\mathrm{x}$ & -0.1 & -4.8 & -4.9 & 1.2 & -4.1 & 0.0 & 0.4 & 0.5 & -1.5 & 0.5 & -0.1 \\
\hline SUR & Suriname & $\mathrm{x}$ & & & & $\mathrm{x}$ & -0.1 & 1.2 & -5.2 & -6.2 & 2.0 & 6.4 & -0.1 & -0.1 & 5.1 & & \\
\hline $\mathrm{BOL}$ & Bolivia & $\mathrm{x}$ & $\mathrm{x}$ & $x$ & $\mathrm{x}$ & $\mathrm{x}$ & 0.1 & 3.3 & -4.3 & 3.3 & -1.0 & 7.6 & -1.7 & 1.6 & -1.6 & -0.5 & 7.0 \\
\hline GTM & Guatemala & $\mathrm{x}$ & $\mathrm{x}$ & $\mathrm{x}$ & $\mathrm{x}$ & $\mathrm{x}$ & 0.5 & 4.5 & 3.0 & 1.3 & 1.9 & 1.5 & -0.7 & 0.6 & 0.5 & 0.4 & 1.5 \\
\hline PRY & Paraguay & $\mathrm{x}$ & $\mathrm{x}$ & $\mathrm{x}$ & & $\mathrm{x}$ & 0.6 & 2.5 & 1.3 & 1.0 & 1.3 & 1.3 & -0.0 & 0.6 & 0.0 & 0.7 & 1.5 \\
\hline $\mathrm{ECU}$ & Ecuador & $\mathrm{x}$ & $\mathrm{x}$ & $\mathrm{x}$ & $\mathrm{x}$ & $\mathrm{x}$ & 0.7 & 3.0 & 1.9 & 1.2 & -4.2 & 1.1 & -5.6 & 0.4 & -0.1 & 2.0 & 1.9 \\
\hline HND & Honduras & $\mathrm{x}$ & $\mathrm{x}$ & $\mathrm{x}$ & $\mathrm{x}$ & $\mathrm{x}$ & 0.8 & 7.3 & -0.3 & 2.5 & 1.5 & 7.6 & -2.0 & 1.2 & -0.0 & 1.8 & 8.0 \\
\hline SLV & El Salvador & $\mathrm{x}$ & $\mathrm{x}$ & $\mathrm{x}$ & $\mathrm{x}$ & $\mathrm{x}$ & 0.8 & 3.2 & -1.4 & 0.9 & 1.1 & 4.6 & -1.7 & 0.7 & -0.8 & 1.7 & 4.9 \\
\hline PER & Peru & $\mathrm{x}$ & $\mathrm{x}$ & $\mathrm{x}$ & $\mathrm{x}$ & $\mathrm{x}$ & 0.9 & 4.0 & 3.0 & 2.1 & -0.8 & 1.1 & -2.9 & 1.3 & 0.3 & 0.6 & 0.9 \\
\hline BHS & Bahamas & $\mathrm{x}$ & & & & $\mathrm{x}$ & 0.9 & 6.1 & 6.0 & 2.1 & 3.0 & 0.1 & 0.2 & 0.2 & 1.6 & & \\
\hline BRA & Brazil & $\mathrm{x}$ & $\mathrm{x}$ & $\mathrm{x}$ & $\mathrm{x}$ & $\mathrm{x}$ & 1.0 & 1.5 & 1.4 & 1.7 & -0.7 & 0.0 & -0.6 & 0.7 & -0.1 & 0.1 & -0.2 \\
\hline BRB & Barbados & $\mathrm{x}$ & & & & $\mathrm{x}$ & 1.0 & 3.3 & 2.8 & 0.8 & 3.4 & 0.4 & 0.6 & 0.9 & -0.3 & 0.9 & 0.4 \\
\hline JAM & Jamaica & $\mathrm{x}$ & $\mathrm{x}$ & $\mathrm{x}$ & $\mathrm{x}$ & $\mathrm{x}$ & 1.0 & 6.1 & 3.2 & 2.6 & 4.3 & 2.9 & 0.6 & 1.1 & 0.2 & 3.0 & 3.7 \\
\hline ARG & Argentina & $\mathrm{x}$ & $\mathrm{x}$ & $\mathrm{x}$ & $\mathrm{x}$ & $\mathrm{x}$ & 1.1 & 1.2 & 1.1 & 1.5 & -1.8 & 0.1 & -1.9 & 0.4 & -0.3 & 1.4 & 0.2 \\
\hline MEX & Mexico & $\mathrm{x}$ & $\mathrm{x}$ & $\mathrm{x}$ & $\mathrm{x}$ & $\mathrm{x}$ & 1.1 & 2.1 & 2.1 & 2.4 & 0.4 & 0.1 & 0.1 & 0.6 & -0.5 & 0.6 & -0.1 \\
\hline GUY & Guyana & $\mathrm{x}$ & $\mathrm{x}$ & & & $\mathrm{x}$ & 1.3 & 17.0 & 2.8 & 0.5 & -3.3 & 15.2 & -9.7 & 2.1 & -1.3 & -6.0 & 6.6 \\
\hline URY & Uruguay & $\mathrm{x}$ & $\mathrm{x}$ & $\mathrm{x}$ & $\mathrm{x}$ & $\mathrm{x}$ & 1.4 & 1.2 & 1.0 & 1.3 & 0.9 & 0.2 & 0.5 & 0.8 & -0.5 & 1.5 & 0.4 \\
\hline $\mathrm{COL}$ & Colombia & $\mathrm{x}$ & $\mathrm{x}$ & $\mathrm{x}$ & $\mathrm{x}$ & $\mathrm{x}$ & 1.6 & 2.1 & 1.8 & 1.9 & 0.9 & 0.3 & 0.7 & 0.7 & -0.1 & 0.8 & 0.4 \\
\hline CRI & Costa Rica & $\hat{x}$ & $\hat{x}$ & $\hat{x}$ & $\hat{x}$ & $\hat{x}$ & 1.7 & 5.6 & 3.9 & 2.7 & -2.4 & 1.7 & $\begin{array}{l}0.7 \\
-3.7\end{array}$ & 1.3 & 1.6 & 0.8 & $\begin{array}{l}.4 \\
1.2\end{array}$ \\
\hline PAN & Panama & $\mathrm{x}$ & $\mathrm{x}$ & $\mathrm{x}$ & $\mathrm{x}$ & $\mathrm{x}$ & 1.9 & 2.6 & 1.9 & 6.0 & -3.0 & 0.7 & -2.2 & 1.1 & -0.6 & 1.5 & 0.2 \\
\hline TTO & Trinidad\& Tobago & $\mathrm{x}$ & $\mathrm{x}$ & $\mathrm{x}$ & & $\mathrm{x}$ & 2.0 & -3.4 & -3.6 & 5.0 & -6.9 & 0.2 & 0.4 & 1.0 & -0.8 & -0.1 & -0.1 \\
\hline DOM & Dominican Rep. & $\mathrm{x}$ & $\mathrm{x}$ & $\mathrm{x}$ & $\mathrm{x}$ & $\mathrm{x}$ & 2.7 & 2.9 & 1.8 & 2.2 & 0.1 & 1.0 & -0.8 & 0.3 & -0.2 & 1.5 & 1.7 \\
\hline BLZ & Belize * & $\mathrm{x}$ & $\mathrm{x}$ & $\mathrm{x}$ & . & $\mathrm{x}$ & 2.8 & 6.6 & 2.1 & 4.1 & 3.6 & 4.9 & 1.1 & 1.1 & -0.1 & 4.4 & 4.8 \\
\hline LCA & Saint Lucia & $\mathrm{x}$ & $\mathrm{x}$ & & & $\mathrm{x}$ & 3.2 & 14.1 & 10.0 & 11.0 & 1.5 & 4.1 & 0.9 & 1.1 & 0.4 & 0.8 & 3.2 \\
\hline GRD & Grenada * & $\mathrm{x}$ & $\mathrm{x}$ & $\dot{x}$ & & $\mathrm{x}$ & 3.5 & 17.0 & 10.2 & 7.8 & 2.4 & 6.8 & 0.8 & 1.1 & 0.5 & 3.5 & 6.9 \\
\hline $\mathrm{CHL}$ & Chile & $\mathrm{x}$ & $\mathrm{x}$ & $\mathrm{x}$ & $\dot{x}$ & $\mathrm{x}$ & 3.6 & 3.2 & 3.1 & 2.1 & -0.5 & 0.1 & -1.8 & 1.1 & -0.2 & 0.2 & -0.3 \\
\hline ATG & Antigua\&Barbuda & $\mathrm{x}$ & & . & . & $\mathrm{x}$ & 3.8 & 13.4 & 11.7 & 11.1 & 0.3 & 1.6 & 0.3 & 0.9 & -0.8 & & \\
\hline KNA & St Kitts\&Nevis & $\hat{x}$ & $\dot{x}$ & & : & $\mathrm{x}$ & 3.8 & 17.5 & 13.2 & 13.9 & 1.8 & 4.2 & 1.0 & 1.0 & 0.1 & 2.7 & 3.4 \\
\hline DMA & Dominica * & $\mathrm{x}$ & $\mathrm{x}$ & $\dot{x}$ & . & $\mathrm{x}$ & 3.9 & 14.8 & 3.9 & 6.7 & 1.3 & 10.9 & 0.5 & 0.9 & 1.1 & 2.6 & 8.8 \\
\hline $\mathrm{VCT}$ & St Vincent\&Gr.* & $\mathrm{x}$ & $\mathrm{x}$ & $\mathrm{x}$ & & $\mathrm{x}$ & 4.1 & 14.1 & 7.6 & 3.1 & 1.5 & 6.5 & 1.1 & 1.1 & 0.6 & 2.1 & 5.7 \\
\hline & $\mathrm{N}$ & 32 & 27 & 24 & 20 & 18 & 32 & 32 & 32 & 32 & 32 & 32 & 32 & 32 & 32 & 29 & 29 \\
\hline & mean & & & & & & 1.6 & 6.3 & 2.6 & 3.2 & -0.0 & 3.8 & -1.6 & 0.9 & 0.0 & 1.3 & 3.6 \\
\hline & sd & & & & & & 1.4 & 6.7 & 4.7 & 3.7 & 2.7 & 4.5 & 4.8 & 0.4 & 1.2 & 2.1 & 4.7 \\
\hline & $\min$ & & & & & & -1.6 & -4.8 & -6.6 & -6.2 & -6.9 & 0.0 & -24.9 & -0.1 & -1.6 & -6.0 & -0.3 \\
\hline & $\max$ & & & & & & 4.1 & 24.6 & 13.2 & 13.9 & 4.3 & 17.0 & 1.1 & 2.1 & 5.1 & 7.3 & 22.0 \\
\hline
\end{tabular}

Notes: Continued on the next page. 
TABle 2 (CONT’D). Net Capital Flows and Growth, by Country, 1980-2007

Out of Whole World Sample

\begin{tabular}{|c|c|c|c|c|c|c|c|c|c|c|c|c|c|c|c|c|c|}
\hline & & & & & & & (1) & (2) & (3) & (4) & (5) & (6) & (7) & (8) & (9) & (10) & (11) \\
\hline & & $\begin{array}{c}\text { Raw } \\
\text { Deve } \\
\text {-loping } \\
\text { Sample }\end{array}$ & $\begin{array}{c}\text { Deve } \\
\text {-loping } \\
\text { Sample }\end{array}$ & $\begin{array}{c}\text { Bench } \\
\text { mark } \\
\text { Sample }\end{array}$ & $\begin{array}{c}\text { PWT } \\
\text { Sample }\end{array}$ & $\begin{array}{c}1970 \\
\text { Sample }\end{array}$ & $\begin{array}{c}\text { GDP per } \\
\text { capita } \\
\text { growth }\end{array}$ & $\begin{array}{l}\text { Net capital } \\
\text { flows/GDP } \\
\text { (-CA/GDP) }\end{array}$ & $\begin{array}{c}\text { Aid-adjusted } \\
\text { net capital } \\
\text { flows/GDP }\end{array}$ & $\begin{array}{c}\text { Net FDI } \\
\text { +Portfolio } \\
\text { Flows/GDP }\end{array}$ & $\begin{array}{c}\text { Net Debt } \\
\text { Flows/GDP }\end{array}$ & $\begin{array}{l}\text { Net total } \\
\text { Aid Receipts } \\
\text { /GDP }\end{array}$ & $\begin{array}{c}\text { Reserve } \\
\text { \& Related } \\
\text { Assets } \\
\text { Accumulation } \\
\text { /GDP }\end{array}$ & $\begin{array}{c}\text { Reserve } \\
\text { Accumulation } \\
\text { /GDP }\end{array}$ & $\begin{array}{l}\text { Net E\&O } \\
\text { /GDP }\end{array}$ & $\begin{array}{c}\text { Net PPG } \\
\text { Debt Flows } \\
\text {-Reserve } \\
\text { Accumulation } \\
\text { /GDP }\end{array}$ & $\begin{array}{c}\text { Net Grants } \\
\text { + Net PPG } \\
\text { Debt Flows } \\
\text { from Official } \\
\text { Creditors } \\
\text { +IMF Credit } \\
\text { - Reserve } \\
\text { Accumulation } \\
\text { /GDP }\end{array}$ \\
\hline \multicolumn{18}{|c|}{ Industrialized OECD Countries Sample } \\
\hline $\mathrm{CHE}$ & Switzerland & & & . & & . & 1.1 & -7.2 & -7.2 & -3.8 & -5.1 & 0.0 & 0.3 & 0.3 & 2.3 & . & . \\
\hline NZL & New Zealand & & ${ }^{\circ}$ & : & & : & 1.4 & 5.6 & 5.6 & 2.0 & 3.0 & 0.0 & -2.1 & 0.7 & 0.7 & . & 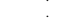 \\
\hline FRA & France & & : & : & & . & 1.5 & -0.3 & -0.3 & -1.1 & 0.8 & 0.0 & 0.1 & 0.1 & -0.0 & : & . \\
\hline GRC & Greece & & & & & & 1.6 & 4.8 & 4.8 & $\begin{array}{l}1.0 \\
1.0\end{array}$ & 3.8 & 0.0 & 0.3 & 0.3 & -0.1 & & \\
\hline CAN & Canada & : & & & & & 1.7 & 1.0 & $\begin{array}{l}4.0 \\
1.0\end{array}$ & -0.9 & 1.5 & 0.0 & 0.1 & 0.2 & -0.2 & & \\
\hline ITA & Italy & & : & : & & : & 1.7 & 0.5 & 0.5 & -0.9 & 1.7 & 0.0 & 0.0 & 0.0 & -0.4 & : & . \\
\hline DEU & Germany & & : & : & & : & 1.7 & -1.3 & -1.3 & -1.1 & -0.4 & 0.0 & 0.0 & 0.0 & $\begin{array}{l}-0.4 \\
0.4\end{array}$ & : & : \\
\hline $\begin{array}{l}\text { DEU } \\
\text { DNK }\end{array}$ & $\begin{array}{l}\text { Germany } \\
\text { Denmark }\end{array}$ & & : & : & & : & 1.8 & $\begin{array}{l}-1.3 \\
-0.2\end{array}$ & $\begin{array}{l}-1.3 \\
-0.2\end{array}$ & $\begin{array}{l}-1.1 \\
-1.4\end{array}$ & $\begin{array}{l}-0.4 \\
1.9\end{array}$ & $\begin{array}{l}0.0 \\
0.0\end{array}$ & $\begin{array}{l}0.0 \\
0.5\end{array}$ & $\begin{array}{l}0.0 \\
0.5\end{array}$ & $\begin{array}{c}0.4 \\
-0.2\end{array}$ & : & : \\
\hline $\begin{array}{l}\text { DNK } \\
\text { BEL }\end{array}$ & $\begin{array}{l}\text { Denmark } \\
\text { Belgium }\end{array}$ & : & & & & & $\begin{array}{l}1.8 \\
1.9\end{array}$ & $\begin{array}{l}-0.2 \\
-2.8\end{array}$ & $\begin{array}{l}-0.2 \\
-2.8\end{array}$ & $\begin{array}{l}-1.4 \\
-0.8\end{array}$ & $\begin{array}{l}1.9 \\
-1.2\end{array}$ & $\begin{array}{l}0.0 \\
0.0\end{array}$ & $\begin{array}{c}0.5 \\
-0.2\end{array}$ & $\begin{array}{c}0.5 \\
-0.2\end{array}$ & $\begin{array}{l}-0.2 \\
-0.1\end{array}$ & & \\
\hline USA & United States & & & & : & & 1.9 & 2.6 & 2.6 & -0.1 & 2.5 & 0.0 & 0.0 & 0.0 & 0.2 & & \\
\hline NLD & Netherlands & & & $\therefore$ & & : & 2.0 & -4.0 & -4.0 & $\begin{array}{l}-3.7 \\
-3.7\end{array}$ & 0.9 & 0.0 & 0.1 & 0.1 & -0.7 & : & : \\
\hline SWE & Sweden & & $\therefore$ & : & & : & 2.0 & $\begin{array}{l}-4.0 \\
-1.7\end{array}$ & $\begin{array}{l}-4.0 \\
-1.7\end{array}$ & $\begin{array}{l}-3.2 \\
-2.2\end{array}$ & $\begin{array}{l}0.9 \\
0.9\end{array}$ & 0.0 & $\begin{array}{l}0.1 \\
-0.7\end{array}$ & 0.3 & $\begin{array}{l}-1.0 \\
-1.0\end{array}$ & : & : \\
\hline AUS & Australia & : & : & & : & & 2.0 & $\begin{array}{l}-1,1 \\
4.5\end{array}$ & $\begin{array}{l}-1.1 \\
4.5\end{array}$ & 0.8 & $\begin{array}{l}0.9 \\
3.9\end{array}$ & 0.0 & 0.2 & 0.2 & $\begin{array}{l}-0.1 \\
-0.1\end{array}$ & & \\
\hline AUT & $\begin{array}{l}\text { Austrina } \\
\text { Austria }\end{array}$ & & . & & : & & 2.0 & 0.3 & $\begin{array}{l}4.3 \\
0.3\end{array}$ & $\begin{array}{l}0.8 \\
-0.4\end{array}$ & 1.1 & 0.0 & 0.1 & 0.1 & $\begin{array}{l}-0.1 \\
-0.2\end{array}$ & & \\
\hline $\begin{array}{l}\text { AUL } \\
\text { ISL }\end{array}$ & $\begin{array}{l}\text { Iceland } \\
\text {. }\end{array}$ & & & . & & . & 2.1 & 5.0 & 5.0 & -5.2 & $\begin{array}{l}1.1 \\
11.8\end{array}$ & 0.0 & $\begin{array}{l}0.1 \\
0.7\end{array}$ & $\begin{array}{l}0.1 \\
0.7\end{array}$ & $\begin{array}{l}-0.2 \\
-0.9\end{array}$ & : & : \\
\hline JPN & Japan & & & & . & & 2.2 & -2.5 & -2.5 & -0.3 & -1.3 & 0.0 & 0.7 & 0.7 & -0.0 & & \\
\hline ESP & Spain & . & & & & & 2.3 & 2.6 & 2.6 & -0.3 & 3.0 & 0.0 & 0.1 & 0.1 & -0.4 & & \\
\hline PRT & Portugal & & & & & & 2.4 & 4.9 & 4.9 & 1.2 & 2.9 & 0.0 & 0.5 & 0.5 & 0.6 & & \\
\hline GBR & United Kingdom & & & . & & . & 2.4 & 1.3 & 1.3 & -1.3 & 2.3 & 0.0 & 0.1 & 0.1 & 0.3 & $\therefore$ & $\therefore$ \\
\hline NOR & Norway & & . & . & & . & 2.4 & -5.7 & -5.7 & -2.4 & -0.2 & 0.0 & 1.0 & $\begin{array}{l}0.0 \\
1.0\end{array}$ & -1.9 & $\therefore$ & $\therefore$ \\
\hline FIN & Finland & . & & & & & 2.5 & -1.5 & -1.5 & -1.1 & 0.6 & 0.0 & 0.3 & 0.3 & -0.8 & & \\
\hline IRL & $\begin{array}{l}\text { Ireland } \\
\text { Ind }\end{array}$ & & & & & & 3.0 & 1.8 & 1.8 & 12.8 & -11.1 & 0.0 & 0.4 & 0.4 & 0.2 & & \\
\hline & $\mathrm{N}$ & & & & & & 22 & 22 & 22 & 22 & 22 & 22 & 22 & 22 & 22 & 0 & 0 \\
\hline & mean & & & & & & 2.0 & 0.4 & 0.4 & -0.4 & 1.1 & 0.0 & 0.1 & 0.3 & -0.1 & & \\
\hline & $\begin{array}{l}\text { mean } \\
\text { sd }\end{array}$ & & & & & & 0.4 & $\begin{array}{l}0.4 \\
3.5\end{array}$ & $\begin{array}{l}0.4 \\
3.5\end{array}$ & 3.4 & 4.1 & 0.0 & $\begin{array}{l}0.1 \\
0.6\end{array}$ & 0.3 & 0.8 & : & : \\
\hline & $\min$ & & & & & & 1.1 & -7.2 & -7.2 & -5.2 & -11.1 & 0.0 & -2.1 & -0.2 & -1.9 & $\therefore$ & $\therefore$ \\
\hline & $\max$ & & & & & & 30 & 56 & 56 & 128 & 118 & 0.0 & 10 & 10 & 23 & & \\
\hline
\end{tabular}

Notes: All flows are expressed as percent of GDP. The countries are divided into geographic regions according to the World Bank classification. Details of variables are in Appendix A and the countries included in several samples used in the paper are marked by "X". Countries with average population less than 1 million are marked with "*". The samples are defined in Table 3 and Appendix B. 
TABle 3. Net Capital Flows and Growth I: 1980-2007

\begin{tabular}{|c|c|c|c|c|c|c|c|}
\hline & (1) & (2) & (3) & (4) & (5) & (6) & (7) \\
\hline \multirow[t]{3}{*}{ Dependent Variable } & \multicolumn{7}{|c|}{ Net capital flows (-CA/GDP) } \\
\hline & \multicolumn{5}{|c|}{$\begin{array}{l}\text { Samples with Annual Net Capital Flows and } \\
\text { Growth Data Available for at Least } 10 \text { Years }\end{array}$} & \multicolumn{2}{|c|}{$\begin{array}{l}\text { For Comparison with } \\
\text { Literature Only }\end{array}$} \\
\hline & Raw World & Raw Developing & Developing & Benchmark & $\begin{array}{l}\text { Benchmark } \\
\text {-Countries } \\
\text { w/ Population } \\
<1 \text { mill }\end{array}$ & PWT & 1970 \\
\hline \multirow[t]{2}{*}{$\begin{array}{l}\text { Sample } \\
\text { Construction }\end{array}$} & $\begin{array}{l}\text { Countries } \\
\text { with } \\
10 \text { years } \\
\text { of Obs. } \\
\text { for CA and } \\
\text { Growth }\end{array}$ & $\begin{array}{c}\text { Raw World } \\
-22 \text { advanced } \\
\text { OECD } \\
\text { Countries }\end{array}$ & $\begin{array}{l}\text { Raw Dev. } \\
\text {-Outliers for } \\
\text { Growth, CA } \\
\text {-Countries w/ } \\
\text { Missing Debt } \\
\text { Components }\end{array}$ & $\begin{array}{l}\text { Raw Dev. } \\
\text {-Outliers for } \\
\text { Growth, CA } \\
\text { and Debt } \\
\text { Components }\end{array}$ & & & \\
\hline & \multicolumn{7}{|c|}{ Panel A: Estimated by the OLS Regression } \\
\hline \multirow[t]{2}{*}{$\begin{array}{l}\text { Average per capita } \\
\text { GDP growth }\end{array}$} & $\begin{array}{l}0.468^{*} \\
(0.285)\end{array}$ & $\begin{array}{l}0.447^{+} \\
(0.282)\end{array}$ & $\begin{array}{c}0.254 \\
(0.214)\end{array}$ & $\begin{array}{c}0.227 \\
(0.203)\end{array}$ & $\begin{array}{c}0.068 \\
(0.223)\end{array}$ & $\begin{array}{c}-0.949 * * * \\
(0.258)\end{array}$ & $\begin{array}{c}-0.901 * \\
(0.476)\end{array}$ \\
\hline & \multicolumn{7}{|c|}{ Panel B: Estimated by the Regression Robust to Outliers } \\
\hline \multirow[t]{2}{*}{$\begin{array}{l}\text { Average per capita } \\
\text { GDP growth }\end{array}$} & $\begin{array}{l}0.328^{*} \\
(0.171)\end{array}$ & $\begin{array}{l}0.308^{*} \\
(0.162)\end{array}$ & $\begin{array}{c}0.216 \\
(0.216)\end{array}$ & $\begin{array}{c}0.169 \\
(0.209)\end{array}$ & $\begin{array}{c}0.045 \\
(0.199)\end{array}$ & $\begin{array}{l}-0.862 * * * * \\
(0.214)\end{array}$ & $\begin{aligned}-0.887 * * * & \\
& (0.255)\end{aligned}$ \\
\hline & \multicolumn{7}{|c|}{ Panel C: Estimated by the Least Absolute Deviations Regression } \\
\hline $\begin{array}{l}\text { Average per capita } \\
\text { GDP growth }\end{array}$ & $\begin{array}{c}0.212 \\
(0.221)\end{array}$ & $\begin{array}{l}0.391^{*} \\
(0.223)\end{array}$ & $\begin{array}{c}0.066 \\
(0.245)\end{array}$ & $\begin{array}{l}-0.086 \\
(0.242)\end{array}$ & $\begin{array}{l}-0.040 \\
(0.228)\end{array}$ & $\begin{array}{l}-0.619 * * * \\
(0.181)\end{array}$ & $\begin{array}{c}-0.501^{*} \\
(0.289)\end{array}$ \\
\hline Obs. & 165 & 143 & 116 & 112 & 96 & 67 & 46 \\
\hline
\end{tabular}

Notes: Robust standard errors are in parentheses. ***,**,*, ${ }^{+}$denote significance at $1 \%, 5 \%, 10 \%, 15 \%$ levels. Robust regressions in Panel B are estimated by Stata command -rreg- which first eliminates large outliers based on Cook's D statistics $>1$ and then performs iterations by repeatedly estimating a regression, calculating country weights from absolute residuals using two different weighting functions, and regressing again using those weights until the maximum change in weights drops below the small pre-set tolerance. "Net capital flows (-CA/GDP)" represents the average over 1980-2007 of the annual current account balance with the sign reversed in current U.S. dollars, normalized by GDP in current U.S. dollars (times 100). Average per capita GDP growth represents the annual rate of change of GDP per capita in 2000 U.S. dollars (times 100) during 1980-2007. "Raw World" sample includes 22 advanced OECD countries and all non-OECD countries where data on their current account balances and GDP per capita is available more than 30 percent of the sample over the 1980-2007. "Raw Developing" sample excludes 22 advanced OECD countries. "Developing" is "Raw Developing" sample minus the outlier countries based on formal econometric outlier tests in terms of capital flows and growth, as described in Appendix B. "Benchmark" sample is "Raw Developing" sample minus the outlier countries based on formal econometric outlier tests in terms of the components of capital flows (equity and public and publiclyguaranteed debt) and growth, as described in Appendix B. Sample in column (5) excludes the countries with average population less than 1 million from the "Benchmark" sample (results when we exclude countries with average population of 0.5 or 0.25 million are similar). "PWT" sample is a subsample of "Raw Developing" sample where capital stock estimates based on the Penn World Tables version 6.1 data is available since 1980s. "1970" is a subsample of "Raw Developing" sample where data on GDP, total foreign assets and liabilities, foreign reserves (excluding gold), and stock of public and publicly-guaranteed external debt are available since 1970s, and 1970 GDP per capita is less than 10,000 in 2000 US dollars. Details of other variables are in Appendix A and the countries included are listed in Table 2. 


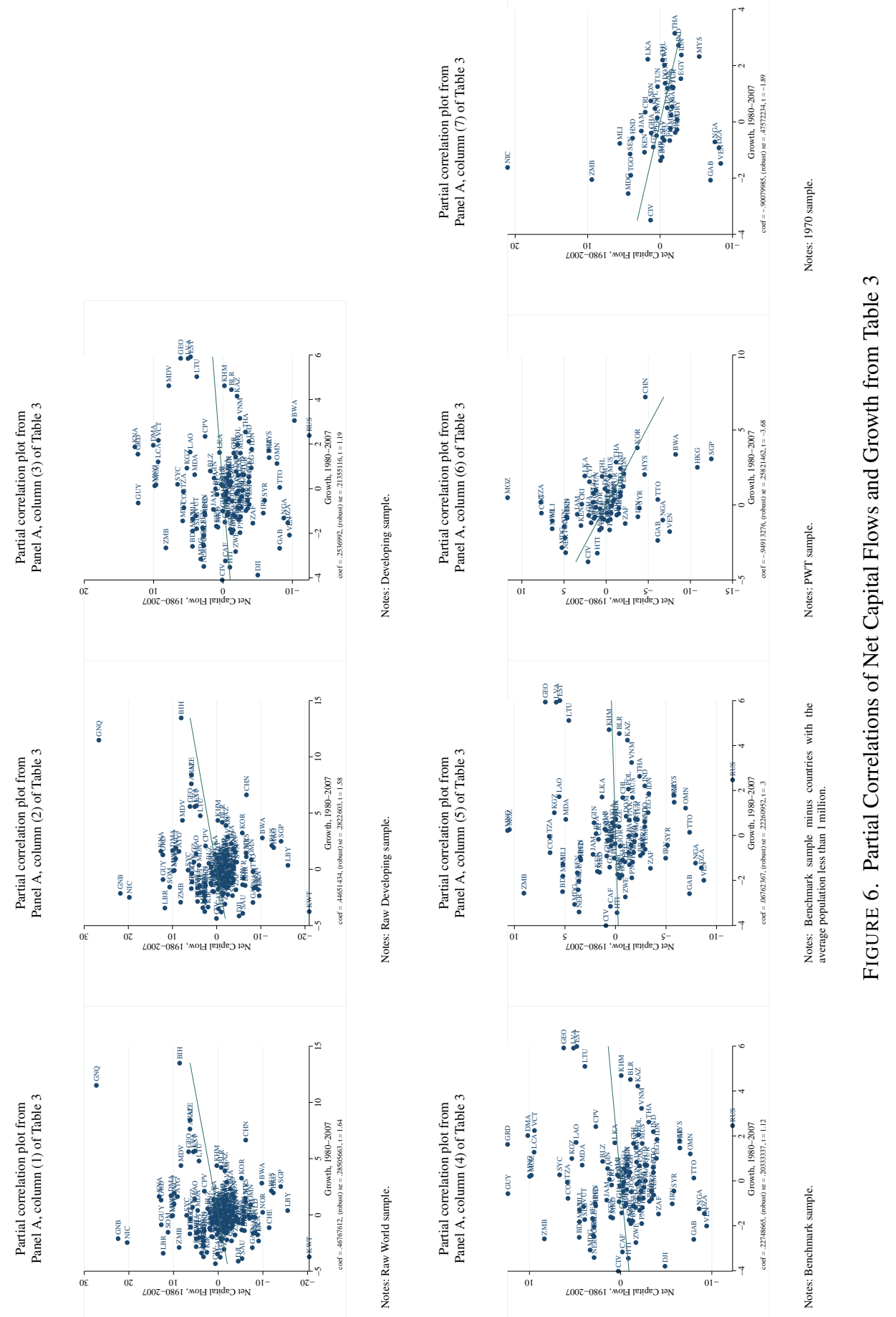


(1)

(2)

(3)
(5)

Dependent Variable

Net capital flows (-CA/GDP)

Samples with Annual Net Capital Flows and

Growth Data Available for at Least 13 Years

\begin{tabular}{|c|c|c|c|c|}
\hline Sample & Raw World & Raw Developing & Developing & Benchmark \\
\hline $\begin{array}{l}\text { Sample } \\
\text { Construction }\end{array}$ & $\begin{array}{c}\text { Countries } \\
\text { with } \\
13 \text { years } \\
\text { of Obs. } \\
\text { for CA and } \\
\text { Growth }\end{array}$ & $\begin{array}{c}\text { Raw World } \\
-22 \text { advanced } \\
\text { OECD } \\
\text { Countries }\end{array}$ & $\begin{array}{l}\text { Raw Dev. } \\
\text {-Outliers for } \\
\text { Growth, CA } \\
\text {-Countries w/ } \\
\text { Missing Debt } \\
\text { Components }\end{array}$ & $\begin{array}{l}\text { Raw Dev. } \\
\text {-Outliers for } \\
\text { Growth, CA } \\
\text { and Debt } \\
\text { Components }\end{array}$ \\
\hline
\end{tabular}

Benchmark

-Countries

w/ Population

$<1$ mill

Sample

Construction

Average per capita

GDP growth

0.176

(0.240)

0.168

(0.238)

0.200

(0.242)

0.263

$(0.241)$
0.023

$(0.249)$

Panel B: Estimated by the Regression Robust to Outliers

$\begin{array}{lccccc}\text { Average per capita } & 0.225 & 0.243 & -0.152 & -0.043 & -0.163 \\ \text { GDP growth } & (0.192) & (0.192) & (0.236) & (0.232) & (0.229)\end{array}$

Panel C: Estimated by the Least Absolute Deviations Regression

$\begin{array}{lccccc}\text { Average per capita } & 0.018 & 0.086 & -0.092 & 0.034 & -0.145 \\ \text { GDP growth } & (0.223) & (0.239) & (0.218) & (0.258) & (0.258)\end{array}$

$\begin{array}{llllll}\text { Obs. } & 156 & 134 & 108 & 98 & 86\end{array}$

Notes: Robust standard errors are in parentheses. $* * *, * *, *,+$ denote significance at $1 \%, 5 \%, 10 \%, 15 \%$ levels. Robust regressions in Panel B are estimated by Stata command -rreg- which first eliminates large outliers based on Cook's D statistics $>1$ and then performs iterations by repeatedly estimating a regression, calculating country weights from absolute residuals using two different weighting functions, and regressing again using those weights until the maximum change in weights drops below the small pre-set tolerance. "Net capital flows (-CA/GDP)" represents the average over 1980-2007 of the annual current account balance with the sign reversed in current U.S. dollars, normalized by GDP in current U.S. dollars (times 100). Average per capita GDP growth represents the annual rate of change of GDP per capita in 2000 U.S. dollars (times 100) during 1980-2007. "Raw World" sample includes 22 advanced OECD countries and all non-OECD countries where data on their current account balances and GDP per capita is available more than 30 percent of the sample over the 1980-2007. "Raw Developing" sample excludes 22 advanced OECD countries. "Developing" is "Raw Developing" sample minus the outlier countries based on formal econometric outlier tests in terms of capital flows and growth, as described in Appendix B. "Benchmark" sample is "Raw Developing" sample minus the outlier countries based on formal econometric outlier tests in terms of the components of capital flows (equity and public and publiclyguaranteed debt) and growth, as described in Appendix B. Sample in column (5) excludes the countries with average population less than 1 million from the "Benchmark" sample (results when we exclude countries with average population of 0.5 or 0.25 million are similar). "PWT" sample is a subsample of "Raw Developing" sample where capital stock estimates based on the Penn World Tables version 6.1 data is available since 1980s. "1970" is a subsample of "Raw Developing" sample where data on GDP, total foreign assets and liabilities, foreign reserves (excluding gold), and stock of public and publicly-guaranteed external debt are available since 1970s, and 1970 GDP per capita is less than 10,000 in 2000 US dollars. Details of other variables are in Appendix A and the countries included are listed in Table 2 . 
Partial correlation plot from Panel A, column (1) of Table 4

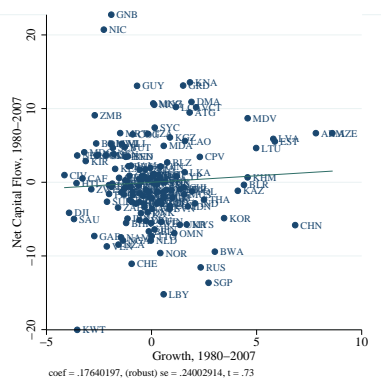

Notes: Raw World sample.

Partial correlation plot from Panel A, column (3) of Table 4

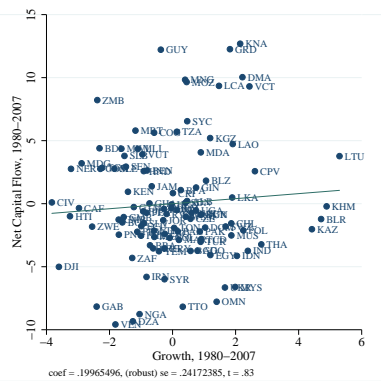

Notes: Developing sample.
Partial correlation plot from Panel A, column (2) of Table 4

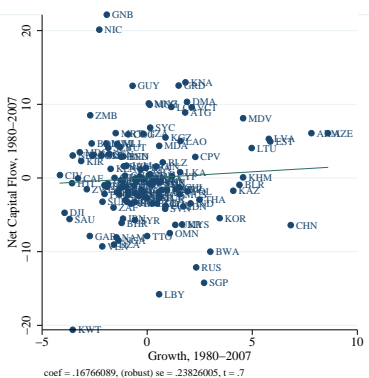

Notes: Raw Developing sample.

Partial correlation plot from Panel A, column (4) of Table 4

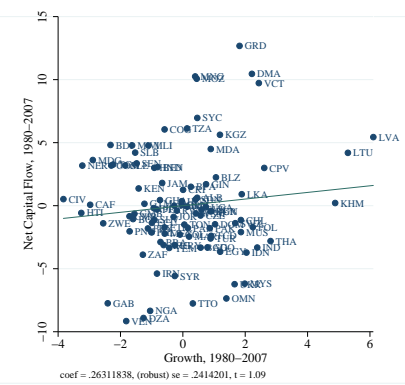

Notes: Benchmark sample.

Partial correlation plot from Panel A, column (5) of Table 4

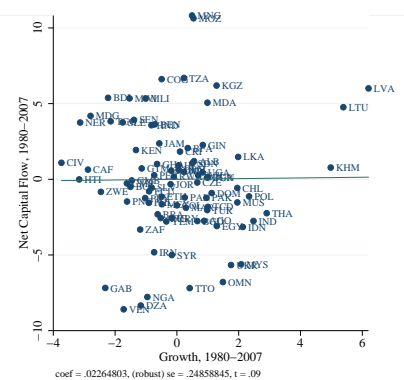

Notes: Benchmark sample minus countries with the average population less than 1 million.

FIgure 7. Partial Correlations of Net Capital Flows and Growth from Table 4 
TABle 5. Net Capital Flows and Growth, 1980-2007: Decomposing Net Capital Flows

Sample: Benchmark

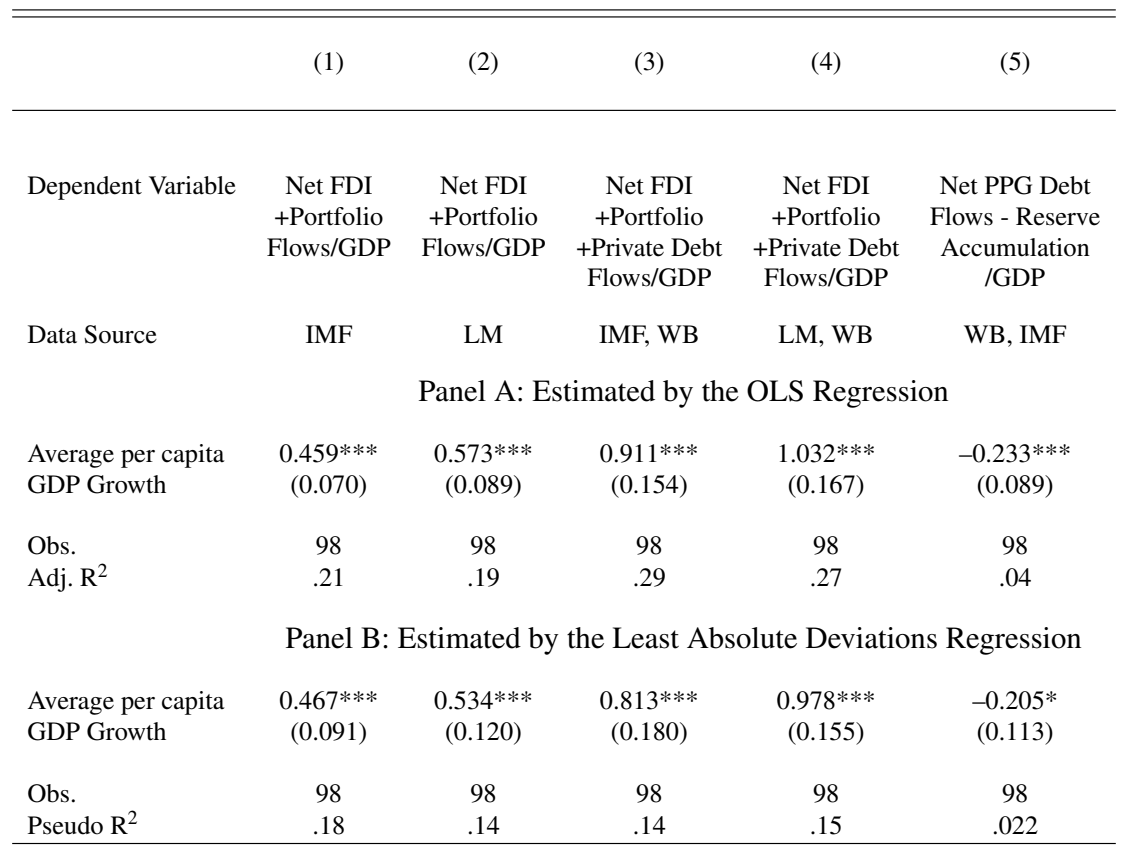

Notes: Robust standard errors are in parentheses. $* * *, * *, *$ denote significance at $1 \%, 5 \%, 10 \%$ levels. "Net FDI +Portfolio Flows/GDP" represents the average over 1980-2007 of the annual flows of foreign liabilities minus annual flows of foreign assets in current U.S. dollars, normalized by GDP in current U.S. dollars (times 100). Annual flows are computed as the difference between FDI plus portfolio equity investment liability and asset flows in current U.S. dollars from the IMF (under source "IMF") or as annual changes in stocks of FDI plus portfolio equity investment liabilities minus annual changes in assets in current U.S. dollars, adjusted for valuation effects normalized by nominal GDP in U.S. dollars (under source "LM"). "Net FDI +Portfolio +Private Debt Flows /GDP" adds the annual changes in stocks of total debt from private creditors (private non-guaranteed debt and public and publicly-guaranteed debt from private creditors) from WB to net FDI+Portfolio Flows/GDP computed from the IMF or LM data. "Net PPG Debt Flows - Reserve Accumulation" the average over 1980-2007 of the annual changes in stock of public and publicly-guaranteed external debt in current U.S. dollars minus the annual flows of foreign reserve assets (excluding gold), with sign reversed, in current U.S. dollars, normalized by GDP in current U.S. dollars (times 100). Average per capita GDP Growth is calculated as the average over 1980-2007 of the annual change of GDP per capita in 2000 U.S. dollars (times 100). Details of other variables are in Appendix A, samples are defined in Table 3 and Appendix B, and the countries included are listed in Table 2 . 

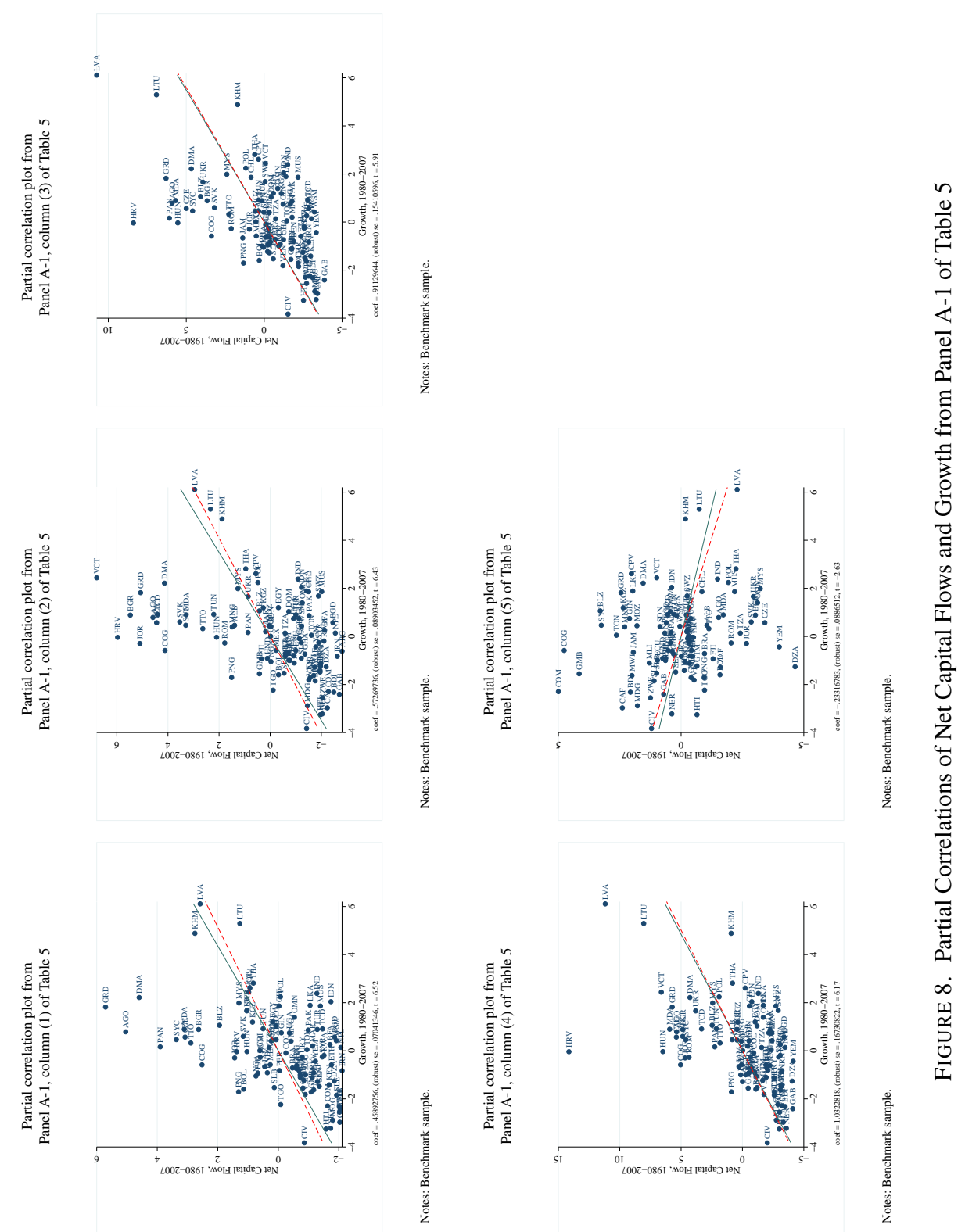
TABle 6. Debt Flows and Growth, 1980-2007: Decomposing Net Debt Flows

Sample: Benchmark

(1)

(2)

(3)

(4)

\section{Panel A: Net Long-term and Short-term Debt Flows}

$\begin{array}{lcc}\begin{array}{l}\text { Dependent } \\ \text { Variable }\end{array} & \begin{array}{c}\text { Net Long-term } \\ \text { Debt Flows/ } \\ \text { GDP }\end{array} & \begin{array}{c}\text { Net Short-term } \\ \text { Debt Flows/ } \\ \text { GDP }\end{array} \\ \text { Average per capita } & 0.343^{* *} & 0.326^{* *} \\ \text { GDP growth } & (0.132) & (0.152) \\ \text { Obs. } & 98 & 98 \\ \text { Adj. } \mathrm{R}^{2} & .11 & .23\end{array}$

Panel B: Selected Components of Public Debt Flows

$\begin{array}{lcccc}\begin{array}{l}\text { Dependent } \\ \text { Variable }\end{array} & \begin{array}{c}\text { Net } \\ \text { Bilateral } \\ \text { PPG Debt } \\ \text { Flows/GDP }\end{array} & \begin{array}{c}\text { Net PPG } \\ \text { Debt Flows } \\ \text { from Official } \\ \text { Creditors/GDP }\end{array} & \begin{array}{c}\text { Reserve } \\ \text { Accumulation/ } \\ \text { GDP }\end{array} & \begin{array}{c}\text { Net Total } \\ \text { Aid Receipts } \\ \text { /GDP }\end{array} \\ \begin{array}{lcccc}\text { Average per capita } \\ \text { GDP growth }\end{array} & -0.052^{*} & -0.123^{*} & 0.172^{* * *} & -0.821^{* *} \\ \text { Obs. } & (0.030) & (0.075) & (0.035) & (0.376) \\ \text { Adj. } \mathrm{R}^{2} & 98 & 98 & 98 & 98 \\ & .0049 & .012 & .076 & .033\end{array}$

Panel C: Selected Components of Private Debt Flows

\begin{tabular}{lcccc}
$\begin{array}{l}\text { Dependent } \\
\text { Variable }\end{array}$ & $\begin{array}{c}\text { Net Private } \\
\text { Non-guarant. } \\
\text { Debt Flows/ } \\
\text { GDP }\end{array}$ & $\begin{array}{c}\text { Net PPG Debt } \\
\text { Flows from } \\
\text { Private } \\
\text { Creditors/GDP }\end{array}$ & $\begin{array}{c}\text { Net Total Debt } \\
\text { Flows from } \\
\text { Private } \\
\text { Creditors/GDP }\end{array}$ & $\begin{array}{c}\text { Aid-adjusted } \\
\text { Net Capital } \\
\text { Flows/GDP }\end{array}$ \\
$\begin{array}{lcccc}\text { Average per capita } \\
\text { GDP growth }\end{array}$ & $\begin{array}{c}0.331^{* *} \\
(0.141)\end{array}$ & $\begin{array}{c}0.135^{* * *} \\
(0.038)\end{array}$ & $\begin{array}{c}0.466^{* * *} \\
(0.147)\end{array}$ & $\begin{array}{c}1.185^{* * *} \\
(0.372)\end{array}$ \\
Obs. & 98 & 98 & 98 & 98 \\
Adj. $\mathrm{R}^{2}$ & .2 & .087 & .23 & .096 \\
\hline
\end{tabular}

Notes: Robust standard errors are in parentheses. $* * *, * *, *$ denote significance at $1 \%, 5 \%, 10 \%$ levels. All measures of capital flows are in nominal dollars in this table are normalized by nominal GDP in U.S. dollars (times 100). "Net Long-term (Short-term) debt flows/GDP" is average annual long-term (short-term) external debt flows, "Net Bilateral PPG ext. debt flows/GDP" is average annual bilateral PPG debt flows. "Net PPG debt flows from official creditors/GDP" is average annual PPG debt flows from official creditors. "Reserve Accumulation/GDP" is the average over 1980-2007 of the annual flows of foreign reserve assets (excluding gold), with sign reversed. "Net Total Aid Receipts/GDP" is the average over 1980-2007 of the annual receipts of net overseas assistance. "Net Private Non-guarant. debt flows/GDP" is average annual private non-guaranteed debt flows. "Net PPG Debt from Private Creditors/GDP" is the average over 1980-2007 of the annual changes in stock of public and publicly-guaranteed external debt from private creditors. "Net Total Debt from Private Creditors/GDP" is the average over 1980-2007 of the annual changes in stock of total external debt from private creditors. "Aid-adjusted Net Capital Flows/GDP" represents the average over 1980-2007 of the current account balance with the sign reversed minus the annual receipts of net overseas assistance. Average per capita GDP Growth is calculated as the average over 1980-2007 of the annual change of GDP per capita in 2000 U.S. dollars (times 100). Details of the variable calculations are in Appendix A, samples are defined in Table 3 and Appendix $\mathrm{B}$, and the countries included are listed in Table 2 . 
TABLE 7. Reconciling with Literature: Net Capital Flows and Growth, 1980-2000.

Dependent Variable: Total Capital Flows/GDP 0

\begin{tabular}{|c|c|c|c|c|c|}
\hline & (1) & (2) & (3) & (4) & (5) \\
\hline Normalizing and Deflating Flows & \multicolumn{5}{|c|}{ Initial GDP; PPP-Adjusted(GJ) } \\
\hline Sample & \multicolumn{4}{|c|}{ PWT } & Benchmark \\
\hline Data Source & GJ-REStud & $\mathrm{AKV}$ & GJ-REStud & $\mathrm{AKV}$ & $\mathrm{AKV}$ \\
\hline $\begin{array}{l}\text { Productivity Catch-up } \\
\text { Relative to the U.S. }(\pi)\end{array}$ & $\begin{array}{c}-0.697 * \\
(0.377)\end{array}$ & $\begin{array}{c}-0.700^{*} \\
(0.358)\end{array}$ & & & \\
\hline Average per capita GDP growth & & & $\begin{array}{r}-0.093^{+} \\
(0.060)\end{array}$ & $\begin{array}{l}-0.109^{*} \\
(0.062)\end{array}$ & $\begin{array}{l}0.046^{+} \\
(0.031)\end{array}$ \\
\hline Initial Capital Abundance $\left(k_{0} / y_{0}\right)$ & $\begin{array}{l}-0.081 \\
(0.122)\end{array}$ & $\begin{array}{l}-0.066 \\
(0.116)\end{array}$ & $\begin{array}{l}-0.130 \\
(0.118)\end{array}$ & $\begin{array}{l}-0.084 \\
(0.119)\end{array}$ & $\begin{array}{l}-0.006 \\
(0.005)\end{array}$ \\
\hline Initial Debt $\left(d_{0} / y_{0}\right)$ & $\begin{array}{c}0.001 \\
(0.004)\end{array}$ & $\begin{array}{l}-0.054 \\
(0.446)\end{array}$ & $\begin{array}{c}0.004 \\
(0.003)\end{array}$ & $\begin{array}{l}-0.008 \\
(0.441)\end{array}$ & $\begin{array}{l}-0.045 \\
(0.280)\end{array}$ \\
\hline Population Growth $(n)$ & $\begin{array}{l}-0.073 \\
(0.114)\end{array}$ & $\begin{array}{l}-0.001 \\
(0.063)\end{array}$ & $\begin{array}{l}-0.056 \\
(0.115)\end{array}$ & $\begin{array}{l}-0.004 \\
(0.058)\end{array}$ & $\begin{array}{c}0.031 \\
(0.030)\end{array}$ \\
\hline Average KA Openness (Chinn-Ito) & $\begin{array}{l}-0.115^{*} \\
(0.062)\end{array}$ & $\begin{array}{l}-0.070 \\
(0.070)\end{array}$ & $\begin{array}{l}-0.048 \\
(0.088)\end{array}$ & $\begin{array}{c}0.032 \\
(0.093)\end{array}$ & $\begin{array}{l}-0.019 \\
(0.024)\end{array}$ \\
\hline Average KA Openness $\times \pi$ & $\begin{array}{l}-0.455^{*} \\
(0.235)\end{array}$ & $\begin{array}{l}-0.418 \\
(0.278)\end{array}$ & & & \\
\hline $\begin{array}{l}\text { Average KA Openness } \times \\
\text { Average per capita GDP growth }\end{array}$ & & & $\begin{array}{r}-0.033^{+} \\
(0.043)\end{array}$ & $\begin{array}{l}-0.046 \\
(0.047)\end{array}$ & $\begin{array}{l}-0.014 \\
(0.057)\end{array}$ \\
\hline Obs. & 67 & 67 & 67 & 67 & 93 \\
\hline
\end{tabular}

Notes: Under the Data Source "GJ-REStud" this table uses the variables from the officially released dataset from Gourinchas and Jeanne (2013) (GJ) (distributed online at http://restud.oxfordjournals.org/content/early/2013/02/14/restud.rdt004/supp1/DC1), except for Average per capita GDP Growth (calculated by us since not included in the GJ dataset). Under the Data Source "AKV" we calculate the variables ourselves following the approach of these authors exactly and using the same data sources, similar treatment of missing data, and estimation techniques. We do this to be able to extend their methodology to our larger sample and to replicate their results in their smaller sample both with their official data and with our data. "Total Capital Flows/GDP ${ }_{0}$ " is estimated as the initial (1980) net external debt (net foreign asset position plus cumulative net errors and omissions as of 1980) minus the sum of the current account balances over 1980-1999, PPP-adjusted by a deflator computed with PWT ver. 6.1 data and normalized by the initial GDP based on PWT data. The calculation of net capital flows is as follows following GJ: 1) cumulate capital flows using CA data; 2) adjust for PPP; 3) normalize by the initial GDP. Average per capita GDP Growth is calculated as the average over 1980-2000 of the annual change of GDP per capita in 2000 U.S. dollars (times 100). "Productivity Catch-up Relative to the U.S." is estimated following the approach of GJ. Robust standard errors are in parentheses. $* * *, * *, *,+$ denote significance at $1 \%, 5 \%, 10 \%, 15 \%$ levels. Details of other variables are in Appendix A, samples are defined in Table 3 and Appendix B, and the countries included are listed in Table 2. 
TABLE 8. Reconciling with Literature: Decomposing Net Capital Flows I, 1980-2000: Residual Method Replication

\begin{tabular}{|c|c|c|c|c|c|c|}
\hline & (1) & (2) & (3) & (4) & (5) & (6) \\
\hline Normalizing and Deflating Flows & \multicolumn{6}{|c|}{ Initial GDP; PPP-Adjusted(GJ) } \\
\hline Sample Countries & \multicolumn{4}{|c|}{ PWT } & \multicolumn{2}{|c|}{1970} \\
\hline Dependent Variable & $\begin{array}{l}\text { Net Public } \\
\text { Flows/GDP } 0\end{array}$ & $\begin{array}{l}\text { Net Private } \\
\text { Flows } / \mathrm{GDP}_{0}\end{array}$ & $\begin{array}{l}\text { Net Public } \\
\text { Flows/GDP } 0\end{array}$ & $\begin{array}{l}\text { Net Private } \\
\text { Flows/GDP } 0\end{array}$ & $\begin{array}{l}\text { Net Public } \\
\text { Flows/GDP } 0\end{array}$ & $\begin{array}{l}\text { Net Private } \\
\text { Flows/GDP } 0\end{array}$ \\
\hline Method for Decomposing Flows & & Residual & & Residual & & Residual \\
\hline $\begin{array}{l}\text { Measure of Net Public Debt Flows } \\
\text { used to Compute Private Flows } \\
\text { (Residual) }\end{array}$ & & $\begin{array}{l}\text { Net Public } \\
\text { Flows/GDP } \\
\text { from col (1) }\end{array}$ & & $\begin{array}{l}\text { Net Public } \\
\text { Flows/GDP } \\
\text { from col (3) }\end{array}$ & & $\begin{array}{l}\text { Net Public } \\
\text { Flows/GDP } \\
\text { from col (5) }\end{array}$ \\
\hline Data Source & GJ-REStud & GJ-REStud & GJ-REStud & GJ-REStud & AKV & AKV \\
\hline $\begin{array}{l}\text { Productivity Catch-up } \\
\text { Relative to the U.S. }(\pi)\end{array}$ & $\begin{array}{c}-1.182 * * * \\
(0.373)\end{array}$ & $\begin{array}{c}0.428 * * \\
(0.179)\end{array}$ & & & & \\
\hline Average per capita GDP growth & & & $\begin{array}{l}-0.163 * * * \\
(0.056)\end{array}$ & $\begin{array}{c}0.060^{* *} \\
(0.029)\end{array}$ & $\begin{array}{l}-0.062^{*} \\
(0.036)\end{array}$ & $\begin{array}{c}0.082 \\
(0.066)\end{array}$ \\
\hline Initial Capital Abundance $\left(k_{0} / y_{0}\right)$ & $\begin{array}{l}-0.112 \\
(0.114)\end{array}$ & $\begin{array}{c}0.059 \\
(0.093)\end{array}$ & $\begin{array}{r}-0.193^{*} \\
(0.114)\end{array}$ & $\begin{array}{c}0.087 \\
(0.092)\end{array}$ & $\begin{array}{c}0.004 \\
(0.114)\end{array}$ & $\begin{array}{c}0.054 \\
(0.157)\end{array}$ \\
\hline Initial Debt $\left(d_{0} / y_{0}\right)$ & $\begin{array}{l}-0.002 \\
(0.004)\end{array}$ & $\begin{array}{c}0.003 \\
(0.003)\end{array}$ & $\begin{array}{l}-0.000 \\
(0.003)\end{array}$ & $\begin{array}{c}0.002 \\
(0.003)\end{array}$ & $\begin{array}{c}0.516 \\
(0.429)\end{array}$ & $\begin{array}{l}1.270^{+} \\
(0.759)\end{array}$ \\
\hline Population Growth $(n)$ & $\begin{array}{l}-0.148 \\
(0.117)\end{array}$ & $\begin{array}{c}0.072 \\
(0.062)\end{array}$ & $\begin{array}{l}-0.095 \\
(0.107)\end{array}$ & $\begin{array}{c}0.053 \\
(0.060)\end{array}$ & $\begin{array}{l}-0.012 \\
(0.032)\end{array}$ & $\begin{array}{c}0.022 \\
(0.052)\end{array}$ \\
\hline Average KA Openness (Chinn-Ito) & $\begin{array}{l}-0.131^{* *} \\
(0.060)\end{array}$ & $\begin{array}{l}-0.002 \\
(0.051)\end{array}$ & $\begin{array}{r}-0.108^{+} \\
(0.071)\end{array}$ & $\begin{array}{l}-0.010 \\
(0.052)\end{array}$ & $\begin{array}{l}-0.103 \\
(0.074)\end{array}$ & $\begin{array}{l}-0.127 \\
(0.136)\end{array}$ \\
\hline Average KA Openness $\times \pi$ & $\begin{array}{c}-0.693 * * * \\
(0.180)\end{array}$ & $\begin{array}{c}0.222 \\
(0.177)\end{array}$ & $\begin{array}{l}-0.524 * * * \\
(0.194)\end{array}$ & $\begin{array}{c}0.164 \\
(0.170)\end{array}$ & & \\
\hline $\begin{array}{l}\text { Average KA Openness } \times \\
\text { Average per capita GDP growth }\end{array}$ & & & & & $\begin{array}{c}0.033 \\
(0.048)\end{array}$ & $\begin{array}{c}0.050 \\
(0.064)\end{array}$ \\
\hline Obs. & 62 & 62 & 62 & 62 & 46 & 46 \\
\hline
\end{tabular}

Notes: This table replicates the approaches of Gourinchas and Jeanne (2013) and Aguiar and Amador (2011). Under the Variables Source "GJ-REStud" this table uses the variables from the officially released dataset from Gourinchas and Jeanne (2013) (GJ) (distributed online at http://restud.oxfordjournals.org/content/early/2013/02/14/restud.rdt004/suppl/DC1), except for Average per capita GDP Growth (calculated by us since not included in the GJ dataset). Under the Variables Source "AKV" we calculate the variables ourselves following the approach of these authors exactly and using the same data sources, similar treatment of missing data, and estimation techniques. Method for Decomposing Flows "Residual" follows Aguiar and Amador (2011) in that public flows are computed directly while private flows are computed as a residual from total flows once public flows are subtracted. Method for Normalizing and Deflating Flows "GJ" follows Gourinchas and Jeanne (2013) in that the estimates of flows are PPP-adjusted and normalized by the initial GDP. Robust standard errors are in parentheses. ***, **, and * denote significance at $1 \%, 5 \%$, and $10 \%$ levels. Details of other variables are in Appendix A, samples are defined in Table 3 and Appendix B, and the countries included are listed in Table 2. 


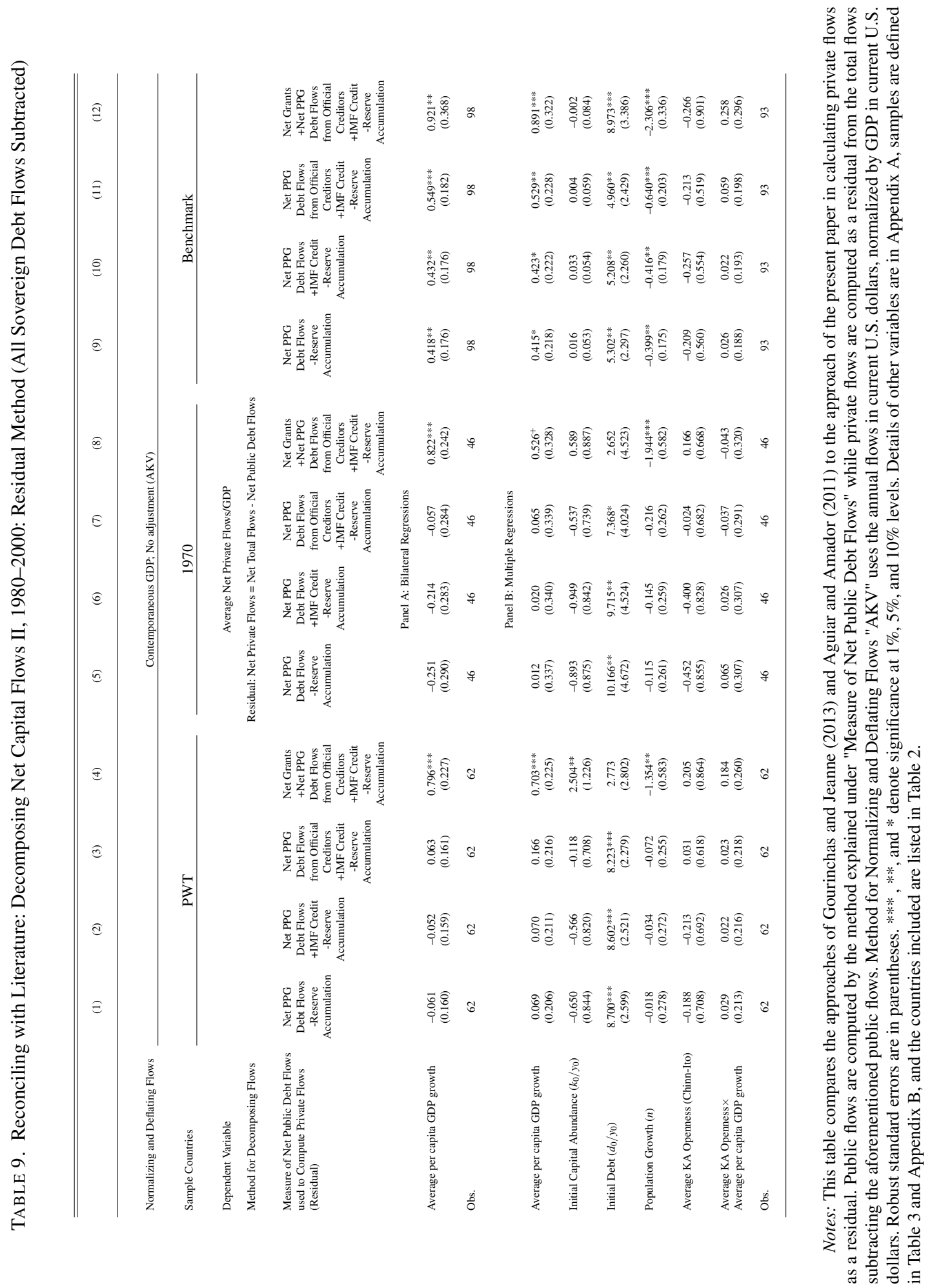


TABLE 10. Reconciling with Literature: Decomposing Net Capital Flows, 1980-2000: Direct Method (Instead of Residual Private Flows)

\begin{tabular}{|c|c|c|c|c|}
\hline & (1) & (2) & (3) & (4) \\
\hline Sample Countries & \multicolumn{4}{|c|}{ Benchmark } \\
\hline Dependent Variable & \multicolumn{4}{|c|}{ Average Net Private Flows/GDP } \\
\hline Method for Decomposing Flows & \multicolumn{4}{|c|}{ Direct } \\
\hline Measure of Net Private Flows & $\begin{array}{c}\text { Average } \\
\text { Net FDI } \\
+ \text { Portfolio } \\
\text { Flows /GDP }\end{array}$ & $\begin{array}{c}\text { Average } \\
\text { Net FDI } \\
+ \text { Portfolio } \\
\text { Flows /GDP }\end{array}$ & $\begin{array}{c}\text { Average } \\
\text { Net FDI } \\
+ \text { Portfolio } \\
\text { +Private Debt } \\
\text { Flows /GDP }\end{array}$ & $\begin{array}{c}\text { Average } \\
\text { Net FDI } \\
\text { +Portfolio } \\
\text { +Private Debt } \\
\text { Flows /GDP }\end{array}$ \\
\hline Data Source & IMF, WB & LM, WB & IMF, WB & LM, WB \\
\hline Normalizing and Deflating Flows & \multicolumn{4}{|c|}{ Contemporaneous GDP; No adjustment(AKV) } \\
\hline
\end{tabular}

Panel A: Bilateral Regressions

Average per capita GDP growth

$\begin{array}{cccc}0.344 * * * & 0.341 * * * & 0.490 * * * & 0.528 * * * \\ (0.100) & (0.113) & (0.146) & (0.154)\end{array}$

Obs.

Adj. $\mathrm{R}^{2}$

98

98

98

98

.13

.12

.11

.13

Panel B: Multiple Regressions

\begin{tabular}{|c|c|c|c|c|}
\hline Average per capita GDP growth & $\begin{array}{l}0.206^{*} \\
(0.113)\end{array}$ & $\begin{array}{l}0.235^{*} \\
(0.122)\end{array}$ & $\begin{array}{c}0.348 * * \\
(0.159)\end{array}$ & $\begin{array}{l}0.395 * * \\
(0.159)\end{array}$ \\
\hline Initial Capital Abundance $\left(k_{0} / y_{0}\right)$ & $\begin{array}{c}0.073 * * * \\
(0.027)\end{array}$ & $\begin{array}{c}0.054 * * \\
(0.025)\end{array}$ & $\begin{array}{l}0.078 * \\
(0.041)\end{array}$ & $\begin{array}{c}0.049 \\
(0.038)\end{array}$ \\
\hline Initial Debt $\left(d_{0} / y_{0}\right)$ & $\begin{array}{c}2.118 \\
(2.110)\end{array}$ & $\begin{array}{c}1.719 \\
(2.215)\end{array}$ & $\begin{array}{c}2.289 \\
(3.230)\end{array}$ & $\begin{array}{c}1.235 \\
(3.456)\end{array}$ \\
\hline Population Growth $(n)$ & $\begin{array}{c}-0.242 * * \\
(0.102)\end{array}$ & $\begin{array}{c}-0.282^{* *} \\
(0.108)\end{array}$ & $\begin{array}{c}-0.695^{* * *} \\
(0.205)\end{array}$ & $\begin{array}{c}-0.735 * * * \\
(0.233)\end{array}$ \\
\hline Average KA Openness (Chinn-Ito) & $\begin{array}{c}0.309 \\
(0.337)\end{array}$ & $\begin{array}{c}0.113 \\
(0.299)\end{array}$ & $\begin{array}{c}0.117 \\
(0.536)\end{array}$ & $\begin{array}{c}0.046 \\
(0.454)\end{array}$ \\
\hline $\begin{array}{l}\text { Average KA Openness } \times \\
\text { Average per capita GDP growth }\end{array}$ & $\begin{array}{l}-0.085 \\
(0.122)\end{array}$ & $\begin{array}{l}-0.054 \\
(0.109)\end{array}$ & $\begin{array}{c}0.048 \\
(0.172)\end{array}$ & $\begin{array}{c}0.074 \\
(0.153)\end{array}$ \\
\hline $\begin{array}{l}\text { Obs. } \\
\text { Adj. } \mathrm{R}^{2}\end{array}$ & $\begin{array}{r}93 \\
.2\end{array}$ & $\begin{array}{l}93 \\
.14\end{array}$ & $\begin{array}{l}93 \\
.27\end{array}$ & $\begin{array}{l}93 \\
.26\end{array}$ \\
\hline
\end{tabular}

Notes: This table presents the "direct" method for calculating private flows by summing up all components of private flows. Robust standard errors are in parentheses. ***, **, and * denote significance at $1 \%, 5 \%$, and $10 \%$ levels. Details of other variables are in Appendix A, samples are defined in Table 4, and the countries included are listed in Appendix B. 


\begin{abstract}
Online appendix (Not for Publication) to
Sovereigns, Upstream Capital Flows, and Global Imbalances

by

Laura Alfaro (Harvard Business School and NBER)

Sebnem Kalemli-Ozcan (University of Maryland, CEPR and NBER)

Vadym Volosovych (Erasmus University Rotterdam, Tinbergen Institute and ERIM)

Contact Information: Alfaro: lalfaro@hbs.edu; Kalemli-Ozcan: kalemli@econ.umd.edu; Volosovych: volosovych@ese.eur.nl
\end{abstract}

\title{
Appendix A: Construction of Variables
}

Our primary sources of the data on annual capital flows are the International Financial Statistics database (IFS) issued by the International Monetary Fund (IMF), the Global Development Finance database (GDF) by the World Bank (WB), and the Development Assistance Committee database (DAC) from the OECD's Development Co-operation Directorate. We also use Lane and Milesi-Ferretti (2007) "External Wealth of Nations Mark II" (LM) data. In addition we rely on the World Bank's World Development Indicators (WDI) database for the macro data.

IFS reports BOP transactions as flows of equity and debt. In 1997, the IMF started reporting stock data, i.e., international investment position for each country. This stock data is computed as cumulated flows. However, the stocks of foreign assets and liabilities depend on past flows, capital gains and losses, and defaults, also refereed to as "valuation effects." LM construct estimates of foreign assets and liabilities and their subcomponents for different countries, paying particular attention to valuation effects. ${ }^{54}$ As we note in the main text, the IMF data does not provide the complete and comprehensive division of debt by private and public issuers and holders. The WB's GDF database provides detailed data on official and private borrowers, only for the countries classified by the WB as developing. Finally, OECD's DAC database presents the detailed data of net development assistance ("aid") for "aid-eligible" recipient countries in developing world. We use all these sources to compute the measure of total net capital flows and decompose them into the private and public components.

\section{Measures of net total capital flows}

Our main measure of net (total) capital flows (referred to throughout as Net Capital Flows $(-C A / G D P))$ is an average of the annual observations for the negative of the current account balance from the IFS normalized by the annual nominal GDP from WDI, both in U.S. dollars.

For our robustness checks and replication exercises we use the cumulated PPPadjusted capital flows measure introduced by Gourinchas and Jeanne (2013). It is

54. LM found that the correlation between the first difference of foreign claims on capital and current account to be generally high but significantly below unity for several countries, confirming the importance of valuation adjustments. 
estimated by the expression

$$
\left[\left(1 / Q_{T}-1 / Q_{0}\right) d_{0}-\sum_{t=0}^{T-1} \frac{C A_{t}}{Q_{T}}\right] / G D P_{0}
$$

as the initial (1980) net external debt $d_{0}$ (net foreign asset position plus cumulative net errors and omissions as of 1980 from LM) minus the sum of the current account balances from the IFS over the 1980-1999 in current dollars, PPP-adjusted by the deflator estimated as (for time 0 ) $Q_{0}=$ Price of Investment ${ }_{0} * \mathrm{CGDP} / \mathrm{RGDP}_{0}$ using the PWT ver. 6.1 data, and then normalized by the initial GDP from the PWT, $G D P_{0}$. We refer to this measure as Total Capital Flows $/ G D P_{0}$.

For the robustness checks in our earlier NBER working paper version (WP 17396) of this paper we use the following alternatives to this measure: i) The change in the net external position between first and last year of the sample period normalized by GDP in the first year, all in current U.S. dollars from LM following earlier versions of Gourinchas and Jeanne (2013); ii) The change in the net external position between first and last year of the sample period normalized by the respective GDPs in those years, all in current U.S. dollars from LM as in LM and also as in Aguiar and Amador (2011).

\section{Equity Flows}

Net FDI+Portfolio Flows/GDP include foreign direct and portfolio equity investment flows. The FDI includes greenfield investments (construction of new factories), investments into the equity capital of existing companies, reinvesting of earnings, and other types of intercompany debt between affiliated enterprizes. Portfolio equity investment includes investments into shares, stock participation, and similar instruments that usually denote ownership of equity. ${ }^{55}$ We compute two versions of net equity flows: i) using the annual changes in stock of direct and portfolio equity liabilities minus the annual changes in stock of direct and portfolio equity assets in current U.S. dollars from LM, and ii) using the annual flows of direct and portfolio equity liabilities minus the annual flows of direct and portfolio equity assets in current U.S. dollars from the IMF. We normalize these flows by annual GDP in current U.S. dollars and average out over the sample period.

\section{Debt Flows}

For the (total) Net Debt Flows/GDP we use annual changes in stock of debt and other investment liabilities minus the annual changes in stock of debt and other investment assets in current U.S. dollars from LM. As before, we normalize it by

55. When a foreign investor purchases a local firm's securities without a controlling stake, the investment is regarded as a portfolio investment. FDI is the equity participation giving a controlling stake. The IMF classifies an investment as direct if as the result of the transaction a foreign investor holds at least 10 percent of a local firm's equity, while the remaining equity purchases are classified under portfolio equity investment. Recently the most of the FDI has been in the form of mergers and acquisitions instead of greenfield investments. In empirical analysis, we do not distinguish between minority and majority shareholders, because this distinction is not relevant for our analysis. 
annual GDP in current U.S. dollars from WB for consistency with other data, and average out over the sample period.

To dig deeper into the issue of public versus private debt flows, we use all the available components of debt flows coming from the WB GDF database. According to the GDF 2012 Manual, $^{56}$ the raw data are reported to the WB in the currency of repayment; the WB then converts them into a common currency (U.S. dollars) using official exchange rates published by the IMF at the annual average exchange rate for flows (commitments, disbursements, and debt service payments) and at the exchange rate in effect at the end of the relevant year for stock concepts (debt outstanding). Because of these practices, there may be differences between the change in aggregate stocks from one period to the next and flows during the relevant period.

The WB derives total debt stock and other aggregate measures by adding up loanlevel data on stocks and flows after conversion to a common currency. WB explains that changes in the stock of debt from one period to the next can be attributed to net flow of debt, net change in interest arrears, the capitalization of interest, a reduction in debt resulting from debt forgiveness or other debt reduction mechanisms, crosscurrency valuation effects. ${ }^{57}$ For this reason, the debt stocks reported in GDF may be regarded as net concepts (stock of liabilities minus stock of assets), and we refer to the annual changes in debt stocks from GDF as annual net debt flows. ${ }^{58}$

As noted in text, the GDF database covers only the countries which are considered developing by the World Bank at the moment a given vintage of the GDF is released. The reason is regulatory. Countries who borrow externally are a part of the World Bank's Debtor Reporting System (DRS) and they are required to report since they receive loans and grants from World Bank, International Bank for Reconstruction and Development and from other international agencies. Borrowers have been required to provide statistics on their public external debt and private sector debt that benefits from a public guarantee and private sector debt that is not guaranteed. In its design, consistency, and continuity of coverage, the DRS is a unique resource. These data is also checked against IMF and BIS statistics for consistency but Lane and MilesiFerretti (2001) note that for developing countries there are discrepancies between the loan flows reported in the IMF's BOP statistics and the changes in the external debt stocks as reported by the WB's GDF database.

Next, we precisely define a number of debt components we consider in this paper.

\section{Components of Debt Flows}

56. Available at http://data.worldbank.org/sites/default/files/gdf_2012.pdf (accessed on 25/10/2012).

57. The final reconciliation of debt stock and flow are sometimes necessary due to individual country phenomena or reported data inconsistencies.

58. The following passage reinforces our belief (p. 324): "private nonguaranteed external debt may be derived as a residual between net long-term external borrowing recorded in the balance of payments and net longterm public and publicly guaranteed external debt reported to the DRS [Debtor Reporting System]" (our italics). 
In a nutshell, total external debt can be divided into long-term, short-term external debt, and and the use of IMF credit, see Figure 1 in the main text. The long-term debt can be divided, by the type of debtor, into private non-guaranteed external debt and public and publicly guaranteed external debt (PPG). The latter can further be divided, by the type of creditor, into PPG debt from official creditors (multilateral and bilateral lenders) and PPG debt from private creditors (commercial banks, bonds, and other).

Net total external debt is defined as the debt owed to nonresidents repayable in foreign currency, goods, or services, and represents the total debt owed to nonresident creditors and repayable in foreign currencies or in goods or services by public and private entities in the country. The major components are short-term debt, long-term debt, and use of the IMF credit.

1. Net Short-Term External Debt: All debt having an original maturity of one year or less and interest in arrears on long-term debt and on the use of IMF credit. The source does not permit the distinction between public and private non-guaranteed short-term debt.

2. Net Long-Term External Debt: Debt that has an original or extended maturity of more than one year and that is owed to nonresidents by residents (both public and private) of an economy and repayable in foreign currency, goods, or services, as well as principal in arrears. Long-term debt has two components: Private non-guaranteed external debt and public and publicly guaranteed long-term debt, aggregated as one item. Public debt is an external obligation of a public debtor, including the national government, a political subdivision (or an agency of either), and autonomous public bodies. Publicly guaranteed debt is an external obligation of a private debtor that is guaranteed for repayment by a public entity.

(a) Net private non-guaranteed external debt, PNG: Long-term external obligations of private debtors that are not guaranteed for repayment by a public entity. It includes the total amount of disbursed and outstanding debt; the amount of disbursements, principal repayments, and interest payments; the principal and interest rescheduled; and the projected principal and interest payments for future years. The data on PNG debt in this publication is as reported or as estimated for countries where this type of external debt is known to be significant.

(b) Net Public and Publicly Guaranteed Debt, PPG: Long-term external obligations of official debtors, including the national government, political subdivisions (or an agency of either), and autonomous public bodies, and external obligations of private debtors that are guaranteed for repayment by a public entity.

- Net PPG from Private Creditors: Includes PPG debt by commercial banks, bondholders, and other private creditors. Commercial bank loans from private banks, other private financial institutions, or private creditors such as manufacturers, exporters, and other suppliers of goods, plus bank credits covered by a guarantee of an export credit. Also included are bank credits covered by a guarantee of an export credit agency. Bonds, which 
are either publicly issued or privately placed, are usually underwritten and sold by a group of banks of the market country and are denominated in that country's currency. Loans from commercial banks and other private lenders comprise bank and trade-related lending.

- Net PPG from Official Creditors: PPG debt from the multilateral and bilateral lenders. In general, official creditors provide loans (and, in some cases, provide grants) to public bodies, although in some cases they may lend to other entities with a public guarantee.

- Net PPG from Multilateral Institutions: Include loans from the World Bank, the regional development banks, and other multilateral and intergovernmental agencies. Excluded are loans administered by such agencies on behalf of a bilateral donor.

- Net PPG Bilateral: Bilateral loans are loans from governments and their agencies, including central banks, aid agencies, official export credit agencies, and autonomous agencies. This item also includes bilateral or officially guaranteed loans by the member-countries of the OECD Development Assistance Committee.

- Net Concessional PPG Debt: Includes concesional PPG debt from bilateral and multilateral lenders. It represents the long-term external debt outstanding and disbursed that conveys information about the borrower's receipt of aid from official lenders at concessional terms as defined by the DAC, that is, loans with an original grant element of 25 percent or more. Loans from major regional development banks: African Development Bank, Asian Development Bank, and the InterAmerican Development Bank, and from the World Bank are classified as concessional, according to each institution's classification and not according to the DAC definition.

(c) Net Total External Debt From Private Creditors: Net Private Non-Guaranteed External Debt plus Net PPG Debt from Private Creditors. Notice, that this aggregate uses only a part of the Net Public and Publicly Guaranteed Debt, $P P G$.

3. Use of the IMF Credit: Denotes members' drawings on the IMF other than those drawn against the country's reserve tranche position. Use of IMF credit includes purchases and drawings under Stand-By, Extended, Structural Adjustment, Enhanced Structural Adjustment, and Systemic Transformation Facility Arrangements, together with Trust Fund loans. Notice that the use of the IMF credit is counted separately from the PPG debt from multilateral institutions.

\section{Aid-adjusted Net Capital Flows and Components of Aid Flows}

We adjust our measure of net capital flows by subtracting aid flows. The aid flows data are net receipts of official development assistance (ODA) from the OECD's DAC 
database. ${ }^{59}$ These aid flows consist of total grants and concessional development loans net of any repayment on the principal. The loans are composed of development loans from World Bank and also other aid flows and loans, most of which are counted as public debt.

Economic development and welfare are regarded the main objective of ODA, in particular, building developing countries' capacity are ODA-eligible and oneoff interventions are not ODA-eligible. Therefore, some flows are not reported as ODA. These are, for example, military aid, the enforcement aspects of peacekeeping, and anti-terrorism activities. In contrast, peacekeeping activities conducted for developmental reasons outside UN peace operations, expenditure on civil police training, social and cultural programmes (e.g., promotion of museums, libraries, art and music schools, and sports training facilities, but not single concert tours or promotion of the culture of the donor), assistance to refugees, the peaceful use of nuclear energy, and research directly and primarily relevant to the problems of developing countries are all counted as ODA.

The OECD DAC database covers the data for countries meet the DAC definition and thus are in "the DAC list of aid recipients." The part II of the DAC list of recipients includes more advanced countries of Central and Eastern Europe, the countries of the former Soviet Union, and certain advanced developing countries and territories. Official aid to these countries has been provided under terms and conditions similar to ODA, but the part II of the DAC list was abolished in 2005 and the collection of data on official aid and other resource flows to Part II countries ended with 2004 data. For this reason, the data for Part II countries were missing when we accessed the OECD database. The World Bank's WDI dataset did retain those countries' data in the series DT.ODA.ALLD.PC.ZS. Conversely, some countries present in the OECD dataset were missing in WDI; mostly they are small island nations, but also countries like Mongolia. We combined the data from both sources to improve the coverage in our time period 1980-2007.

Disbursements are mostly measured on a cash basis, not an accruals basis. Loans for one year or less are not counted as ODA because they are unlikely to have a development impact. Repayments of the principal of ODA loans count as negative flows, and are deducted to arrive at net ODA, so that by the time a loan is repaid, net flow over the period of the loan is zero. Interest is recorded, but is not counted in the net flow statistics. Where official equity investments in a developing country are reported as ODA because of their development intention, proceeds from their later sale are recorded as negative flows, regardless of whether the purchaser is in a developed or a developing country.

59. Official development assistance data we use is compiled by DAC and available at www.oecd.org/dac/stats/idsonline and through World Bank's WDI online database. In particular a note on ODA eligibility can be found at http://www.oecd.org/dac/aidstatistics/34086975.pdf; the full DAC Directives providing definitions and detailed descriptions of the concepts and categories used in the DAC statistics are available at http://www.oecd.org/dac/aidstatistics/38429349.pdf (accessed on 5/11/2012). 
Disbursements are measured on a cash basis, except that:

- wherever contributions to multilateral development banks and funds are made in the form of promissory notes, the full amount of the note is recorded at the time of deposit; and

- the net present value of debt relief provided by implementing a Paris Club debt reorganization through debt service reduction is reportable as an ODA grant in the year of the reorganization.

Some transactions not recorded as transfers in balance of payments statistics are nevertheless eligible to be recorded as ODA, since they represent an effort by the official sector in favor of development. These include the costs of developmentally relevant secondary and tertiary education and vocational training (including stipends and travel) provided to developing country nationals in the donor country, the administrative costs of ODA programmes, subsidies to non-governmental organizations, in donor refugee costs and programmes to raise development awareness in donor countries. Capital investment in the donor country is not regarded as a flow and is therefore not eligible to be reported as ODA. This applies even to the construction and equipment of training and research facilities related to development issues. The running costs of such facilities may, however, be counted as ODA.

Components of Aid Flows

1. Net ODA, also referred to as throughout the present paper as Net Total Aid Receipts: Flows to developing countries and multilateral institutions provided by official agencies, including state and local governments or by their executive agencies, which meet the following criteria: i) it is undertaken by the official sector; ii) the transaction is administered with the promotion of the economic development and welfare of developing countries as its main objective; and iii) it is concessional in character and conveys a grant element of at least 25 percent. The grant element of a loan is defined as the difference between the face value of the loan and the present value of the repayments on the principal and interest over the life of the loan. This difference (i.e., the grant element) is then expressed as a percentage of the loan's face value.

2. Net ODA Loans: Loans with maturities of over one year extended by governments and official agencies for which payment is required in convertible currencies or in kind. Rescheduled loans (loans given maturity extensions and originally made by a government or official agency) and loans originally made by a government or an official agency to refinance indebtedness due to the private or official sector are included if reported as ODA, otherwise they are recorded as other official flows. The net data are reported after deduction of amortization receipts in other than local currencies, including repayments in kind.

3. Net Total Grants: Net ODA flows minus net ODA loans; they are either official (i.e. public body) or private in origin, they include transfers made in cash or in kind in respect of which no legal debt is incurred by the recipients. Included also are grants for reparations and indemnification payments made 
at the government level and technical assistance. However, reparations and indemnification payments to private individuals, insurance, and similar payments to residents of developing countries are excluded. Domestic and overseas administrative costs of aid programs are, in principle, also excluded. Grants are recorded on a net basis.

4. Net ODA flows from Multilateral: Same as net ODA flows but coming from all multilateral institutions.

5. Net ODA loans from Multilateral: Same as net ODA loans but coming from all multilateral institutions.

6. Total Grants Multilateral: Net ODA flows multilateral minus net ODA loans multilateral.

7. Net ODA Flows from IMF: Same as net ODA flows but coming from only the IMF.

8. Net ODA Loans from IMF: Same as net ODA loans but coming from only the IMF.

\section{The Components of Government Savings.}

Current revenue of the consolidated central government, excluding grants: Revenue is cash receipts from taxes, social contributions, and other revenues such as fines, fees, rent, and income from property or sales; from the WB.

Current expenditure of the consolidated central government: Expenditure is cash payments for operating activities of the government in providing goods and services. It includes compensation of employees, interest and subsidies, grants, social benefits, and other expenses such as rent and dividends; from the WB.

Grants and other revenue: Grants and other revenue include grants from other foreign governments, international organizations, and other government units, interest, dividends, rent, requited, non-repayable receipts for public purposes, and voluntary, unrequited, non-repayable receipts other than grants; from the WB.

Capital transfers to abroad: the IMF's BOP series Current Transfers-Debit, with the sign reversed for ease of interpretation, including all transfers that are not transfers of capital; they directly affect the level of disposable income and influence the consumption of goods or services. ${ }^{60}$ The two main categories are (i) general government and (ii)) other sectors. (1) comprise current international cooperation, which covers current transfers - in cash or in kind-between governments of different economies or between governments and international organizations (e.g., current international cooperation between different governments, payments of current taxes on income and wealth, etc.). (ii) comprise those occurring between individuals, between nongovernmental institutions or organizations (or between the two groups),

60. By BOP Fifth Edition (BPM5) convention, all the debit transactions (foreign asset purchases) are included with the minus sign. Current transfers consist of all transfers that do not involve (i) transfers of ownership of fixed assets; (ii) transfers of funds linked to, or conditional upon, acquisition or disposal of fixed assets; (iii) forgiveness, without any counterparts being received in return, of liabilities by creditors. All of these are capital transfers. 
or between nonresident governmental institutions and individuals or nongovernmental institutions (e.g., workers' remittances, premiums-less service charges, and claims on non-life insurance).

Reserve Accumulation: the IMF's BOP series Reserves and Related Items Assets, with the sign reversed for ease of interpretation, which includes the sum of transactions in reserve assets, exceptional financing, and use of the IMF credit and WB loans. The category of Reserve Assets includes monetary gold, SDRs, reserve position in the IMF, foreign exchange assets (such as currency deposits, government and nongovernment securities, and nonmarketable claims arising from arrangements between central banks or governments).

\section{Measures of Capital Flows used in Reconciling Regressions}

Total Capital Flows $/ G D P_{0}$ in Table 7 is defined in the beginning of this Appendix; it is estimated as the initial (1980) net external debt (net foreign asset position plus cumulative net errors and omissions as of 1980) plus the sum of the current account balances over 1980-1999, PPP-adjusted by a deflator computed with PWT ver. 6.1 data and normalized by the initial GDP based on PWT ver. 6.1 data.

Net Public Flows/GDP 0 in Table 8 is estimated as the initial (1980) net public and publicly guaranteed (PPG) debt from WB minus the stock in international reserves excluding gold from LM as of 1980 plus the sum of over 1980-1999 of (annual differences in PPG debt minus annual flows of international reserves excluding gold from IMF IFS), PPP-adjusted and normalized by the initial GDP computed with PWT ver. 6.1 data.

Net Private Flows $/ G D P_{0}$ in Table 8 is calculated as a difference ("residual") of the cumulated PPP-adjusted Total Capital Flows/GDP ${ }_{0}$ and the cumulated PPP-adjusted Public Flows/GDP 0 .

The remainder of the measures is considered in Table 9 and Table 10 or in unreported robustness exercises.

Net Private Flows/GDP in Table 9 is the average over the 1980-2000 of the annual net private capital flows estimated by the "residual method", as percentage of annual GDP, both in current U.S. dollars. Here the annual net private capital flows are a difference (residual) of the total net capital flows we use in present paper (average of the current account balance with the sign reversed) and one of the following proxies of the "Net Public Debt Flows":

1. Net PPG Debt Flows - Reserve Accumulation

2. Net PPG Debt Flows + IMF Credit - Reserve Accumulation

3. Net PPG Debt Flows from Official Creditors + IMF Credit - Reserve Accumulation

4. Net Grants + Net PPG Debt Flows from Official Creditors + IMF Credit - Reserve Accumulation

5. Net Total Aid + Net PPG Debt Flows from Multilateral Creditors + IMF Credit Reserve Accumulation

6. Net Total Aid + IMF Credit - Reserve Accumulation 
7. Net Short-Term Public Debt Flows $+(3)=$ Net Short-Term Public Debt Flows + Net PPG Debt Flows from Official Creditors + IMF Credit - Reserve Accumulation

8. Net Short-Term Public Debt Flows $+(4)=$ Net Short-term Public Debt Flows + Net Grants + Net PPG Debt Flows from Official Creditors + IMF Credit - Reserve Accumulation

9. Net Short-Term Public Debt Flows $+(5)=$ Net Short-Term Public Debt Flows + Net Total Aid + Net PPG Debt Flows from Multilateral Creditors + IMF Credit Reserve Accumulation

where the components of these measures are defined above under Components of Aid Flows and Components of Debt Flows, and Net Short-Term Public Debt Flows is calculated from the data available in GDF as the total sort-term debt flows times the average over time share of PPG debt flows in total long-term debt flows.

The following measures compute net private capital flows directly ("direct measures") by adding up the relevant components of annual capital flows using two alternative data sources. Annual flows are computed as i) the difference between liability and asset flows in current U.S. dollars from the IMF IFS, or ii) as annual changes in stocks of liabilities minus annual changes in assets in current U.S. dollars, adjusted for valuation effects from LM dataset. All the measures are normalized by nominal GDP in U.S. dollars from the WB WDI.

Average Net FDI + Portfolio/GDP (defined above and represents total equity flows) is computed directly as the average over time period of the annual flows of foreign direct investment and portfolio equity liabilities minus annual flows of foreign assets, normalized by GDP in current U.S. dollars.

Average Net FDI + Portfolio + Private Debt Flows/GDP are computed similarly using net annual flows of FDI plus portfolio equity investment plus annual changes in stocks of total debt from private creditors (private non-guaranteed debt and public and publicly-guaranteed debt from private creditors) from WB GDF, normalized by nominal GDP in U.S. dollars.

\section{Explanatory variables used in Reconciling Regressions.}

Average per capita GDP growth is the annual rate of change of GDP per capita in 2000 U.S. dollars (times 100) over 1980-2000 from WB WDI.

Average per capita GDP Growth relative to the U.S. is the geometric mean of the rate of change of GDP per capita in 2000 U.S. dollars relative to that of the U.S. over 1980-2000.

The following explanatory variables are computed following the methods of Gourinchas and Jeanne (2013).

Productivity Catch-up Relative to the U.S. $(\pi)$ is calculated as $\bar{A}_{2000} / g^{*} \cdot \bar{A}_{2000}-1$, where $\bar{A}$ is the Hodrick-Prescott trend of productivity estimate $A_{t}=\left(y_{t} / k_{t}^{\alpha}\right)^{1 /(1-\alpha)}$ and $g^{*}$ is the annual TFP growth observed on average in the U.S. between 1980 and 2000, set to 1.017. In formula for $A_{t}$, the $y_{t}$ denotes GDP per capita and $k_{t}$ is capital stock 
per capita, estimated by the perpetual inventory method from time series data on real investment, assuming a capital share $\alpha$ of 0.3 and a depreciation rate $\delta$ of 6 percent. All the data for the estimation of $\pi$ comes from the PWT ver. 6.1.

Initial Capital Abundance $\left(k_{0} / y_{0}\right)$ is the level of total capital stock, constructed with the perpetual inventory method from time series data on real investment from the PWT ver. 6.1, assuming a capital share 0.3 and a depreciation rate of 6 percent, and normalized by the initial GDP computed with PWT ver. 6.1 data.

Initial Debt $\left(d_{0} / y_{0}\right)$ is estimated as the initial (1980) net external debt (net foreign asset position plus cumulative net errors and omissions as of 1980) from LM.

Population Growth $(n)$ is the growth rate of the working-age population over 1980-2000 from WB.

Average KA Openness (Chinn-Ito) is the average over 1980-2000 value of the capital account openness index from Chinn and Ito (2006).

Average KA Openness $\times$ Average per capita GDP growth is the product (interaction) of Average KA Openness (Chinn-Ito) and Average per capita GDP growth.

Average KA Openness $\times \pi$ is the product (interaction) of Average KA Openness (Chinn-Ito) and Productivity Catch-up Relative to the U.S.

\section{Appendix B: Samples}

Our most inclusive Raw World sample includes 22 advanced OECD countries (Australia, Austria, Belgium, Canada, Switzerland, Germany, Denmark, Spain, Finland, France, United Kingdom, Greece, Ireland, Iceland, Italy, Japan, the Netherlands, Norway, New Zealand, Portugal, Sweden, the United States) and all nonOECD countries where data on their current account balances and the level and growth of GDP per capita is available for a chosen minimum number of years over the 1980$2007 .{ }^{61}$ The choice of the minimum number of years in the initial sample affects the size of all our subsamples, except for PWT and 1970 samples, defined below, that are built using different principles and used for comparison with the literature.

In Table 3 we retain countries with the CA/GDP and growth for a minimum of 10 years (or 35 percent of the time) over the 1980-2007, giving us 165 countries. In the rest of the paper, including Table 1 and 2, we are more conservative and require countries to have that data close a half of the time over the 1980-2007 (minimum 13 years), retaining 156 countries in the Raw World sample.

61. The time coverage of the data varies substantially from country to country and in particular for developing countries. Most developing countries report data starting in the mid-1970s. Some countries drop put from the official releases of the databases, such as GDF, once they reach some level of economic development as we noted above. For other countries, data are not available until the mid 1980s or the early 1990s, such as Eastern Europe. In the former Soviet Union the early years following its collapse witnessed the hyperinflation episodes making the data unreliable until the macro stabilization was achieved for most of countries around 1995. 
The most inclusive Raw Developing sample excludes 22 advanced OECD countries from the Raw World sample (Table 2 indicates the countries in each sample; Appendix Table APP-1 presents the exact time-series coverage).

Formal outlier checks. We construct our developing countries samples based on the formal econometric outlier tests designed to detect the unusual and influential data. We select our samples by removing the influential observations with large residuals, high leverage (an extreme value compared to the sample mean), or both. First, we remove the countries with the predicted Studentized residuals that exceed +3 or -3 and countries with leverage greater than $(2 k+2) / N$ where $k$ is the number of predictors (including the constant) in the linear regression of a relevant measure of capital flows on growth (in our case, $k=2$ ) and $N$ is the number of observations in sample. ${ }^{62}$

Second, we use DFITS statistics (Welsch and Kuh, 1977) and Cook's D statistics (Cook 1977), both of which attempt to summarize the information in the leverage and the size of residuals into one statistic. Cook's D and DFITS are very similar except for scalingand give us very similar answers. We eliminate all countries detected by those two statistics using the convention cut-off point for Cook's D of $4 / N$ and for DFITS of $2 \sqrt{k / N}$.

Third, we use more specific measure of influence called DFBETA that assess how the regression coefficients are changed (increased or decreased) by deleting one observation at a time. This measure is created for our predictor, GDP per capita growth, to measure the difference between the regression coefficient when the $i$ th country is included and excluded, the difference being scaled by the estimated standard error of the coefficient. We follow the recommendation of Belsley, Kuh, and Welsch (1980) and delete countries with abs(DFBETA) $>2 \sqrt{N}$.

Our non-OECD developing country samples, obtained with formal outlier checks, are as follows:

1. Developing sample: A subset of Raw Developing sample including 108 nonOECD countries where the data on their current account balance/GDP and GDP per capita growth is available close to 50 percent of the time over 1980-2007 and whose data for the main underlying components of capital flows (FDI plus portfolio equity/GDP and public and publicly-guaranteed debt/GDP) are nonmissing in at least one year over 1980-2007. ${ }^{63}$ Having non-missing components is important in a number of decompositions of the CA balance we discuss.

We further eliminate the outliers in terms of the (-1)current account balance/GDP and GDP growth using the formal outlier checks described above. Figure APP-1 highlights the essence of these tests by showing the outliers detected in the Raw Developing sample. The upper plot presents the leverage

62. These cutoffs are recommended in Regression with Stata. UCLA: Statistical Consulting Group. Available at http://www.ats.ucla.edu/stat/stata/webbooks/reg/chapter2/statareg2.htm (accessed December 2013).

63. Imposing non-missing PPG debt means that the other debt components are covered in the GDF database. 
against standardized squared residuals. Cook's D and DFITS statistics allow to detect the countries which have a high leverage, or residuals, or both. The lower plot depicts the measure of influence DFBETA. It indicates which countries, when eliminated, result in a large (positive or negative) change of the coefficient in the regression of Net capital flows (-CA/GDP) on Growth as in col(2), Panel A in Table 4. The figure presents the plot of the measure of influence DFBETA from the regression of net capital flows on growth in Raw Developing sample, 1980 2007, as in col(2), Panel A in Table 4. We eliminate the countries which fall outside of the critical bands for DFBETA $(\operatorname{abs}($ DFBETA $)>2 \sqrt{N})$ in this sample, indicated by the solid horizontal lines. With minimum 10 years of CA/GDP and growth data restriction this sample includes 116 countries.

2. Benchmark sample: A subset of Raw Developing sample including 98 non-OECD countries where the data on their current account balance/GDP and GDP per capita growth is available close to 50 percent of the time over 1980-2007. We further eliminate the outliers in terms of the (-1)current account balance/GDP, FDI plus portfolio equity/GDP, public and publicly-guaranteed debt/GDP, and GDP per capita growth using the formal outlier checks described above. Because the tests are sample-specific, we implement them for growth and all chosen measures of capital flows always in a Raw World sample (not sequentially, eliminating the countries and thus reducing the sample size on each step) after which all countries detected by three tests as outliers are deleted. With minimum 10 years of CA/GDP and growth data restriction this sample includes 112 countries.

We also consider several other samples for comparison and reconciling with the literature. No outlier tests have been conducted in these samples.

1. PWT sample: a 67-country subsample of Raw Developing sample where capital stock estimates based on the Penn World Tables version 6.1 data is available 100 percent of the time. This sample plus Taiwan is considered by Gourinchas and Jeanne (2013).

2. 1970 sample: a 46-country subsample of of Raw Developing with 1970's data for GDP, total foreign assets and liabilities, foreign reserves (excluding gold), and stock of public and publicly-guaranteed external debt are non missing 100 percent of time, and 1970 GDP per capita is less than 10,000 of 2000 US dollars. This sample is considered in Aguiar and Amador (2011). 
TABlE APP-1. (Appendix Table) Net Capital Flows and Growth: Country Coverage, 1980-2007

Whole World Sample

\begin{tabular}{|c|c|c|c|c|c|c|c|c|c|c|c|c|c|c|}
\hline & (1) & (2) & (3) & (4) & (5) & (6) & (7) & (8) & (9) & (10) & (11) & (12) & (13) & (14) \\
\hline & & \multicolumn{13}{|c|}{ Measures of Flows } \\
\hline & $\begin{array}{l}\text { GDP per } \\
\text { capita } \\
\text { growth }\end{array}$ & $\begin{array}{l}\text { Net capital } \\
\text { flows } \\
\text { (-CA/GDP) }\end{array}$ & $\begin{array}{l}\text { Net capital } \\
\text { flows } \\
\text { (-NFA/GDP) }\end{array}$ & $\begin{array}{c}\text { Net capital } \\
\text { flows } \\
\text { (-NFA/GDP) }\end{array}$ & $\begin{array}{c}\text { Net FDI } \\
+ \text { +Portfolio } \\
\text { Flows/GDP }\end{array}$ & $\begin{array}{c}\text { Net FDI } \\
\text { +Portfolio } \\
\text { Flows/GDP }\end{array}$ & $\begin{array}{c}\text { Net Debt } \\
\text { Flows/GDP }\end{array}$ & $\begin{array}{l}\text { Net Debt } \\
\text { Flows/GDP }\end{array}$ & $\begin{array}{l}\text { Net Total } \\
\text { Aid Receipts } \\
\text { /GDP }\end{array}$ & $\begin{array}{c}\text { Reserve } \\
\text { \& Related } \\
\text { Assets } \\
\text { Accumulation } \\
\text { /GDP }\end{array}$ & $\begin{array}{l}\text { Reserve } \\
\text { Accumulation } \\
\text { /GDP }\end{array}$ & $\begin{array}{l}\text { Net E\&O } \\
\text { /GDP }\end{array}$ & $\begin{array}{l}\text { Net PPG } \\
\text { Debt Flows } \\
\text {-Reserve } \\
\text { Accumulation } \\
\text { /GDP }\end{array}$ & $\begin{array}{c}\text { Net Grants } \\
\text { +Net PPG } \\
\text { Debt Flows } \\
\text { from Official } \\
\text { Creditors } \\
\text { +IMF Credit } \\
\text {-Reserve } \\
\text { Accumulation } \\
\text { /GDP }\end{array}$ \\
\hline Data source & wB & IMF,WB & IMF,WB & LM & IMF,WB & LM & IMF,WB & LM & OECD,WB & IMF,WB & IMF,WB & IMF,WB & WB & IMF,OECD,WB \\
\hline \multicolumn{15}{|c|}{33 Low-Growth Non-OECD Developing Countries } \\
\hline 1970-2007 & 33 & 33 & 22 & 31 & 33 & 31 & 33 & 31 & 33 & 33 & 33 & 33 & 27 & 27 \\
\hline 1970-1979 & 26 & 25 & 1 & 24 & 25 & 24 & 25 & 24 & 28 & 25 & 25 & 25 & 20 & 20 \\
\hline $1980-1989$ & 30 & 30 & 2 & 29 & 30 & 29 & 30 & 29 & 32 & 30 & 30 & 30 & 24 & 24 \\
\hline 1990-1999 & 33 & 33 & 11 & 31 & 33 & 31 & 33 & 31 & 33 & 33 & 33 & 33 & 27 & 27 \\
\hline 2000-2007 & 33 & 28 & 22 & 31 & 28 & 31 & 28 & 31 & 33 & 28 & 28 & 28 & 23 & 23 \\
\hline $1990-2007$ & 33 & 33 & 22 & 31 & 33 & 31 & 33 & 31 & 33 & 33 & 33 & 33 & 27 & 27 \\
\hline 1980-2007 & 33 & 33 & 22 & 31 & 33 & 31 & 33 & 31 & 33 & 33 & 33 & 33 & 27 & 27 \\
\hline \multicolumn{15}{|c|}{67 Medium-Growth Non-OECD Developing Countries } \\
\hline 1970-2007 & 67 & 67 & 45 & 66 & 67 & 66 & 67 & 66 & 67 & 67 & 67 & 67 & 63 & 63 \\
\hline 1970-1979 & 46 & 47 & 0 & 46 & 47 & 46 & 47 & 46 & 49 & 47 & 47 & 47 & 43 & 43 \\
\hline 1980-1989 & 60 & 59 & 3 & 54 & 58 & 54 & 59 & 54 & 60 & 59 & 59 & 59 & 54 & 54 \\
\hline 1990-1999 & 66 & 67 & 26 & 66 & 66 & 66 & 67 & 66 & 67 & 67 & 67 & 67 & 63 & 63 \\
\hline 2000-2007 & 67 & 66 & 51 & 66 & 65 & 66 & 66 & 66 & 67 & 66 & 66 & 66 & 62 & 62 \\
\hline $1990-2007$ & 67 & 67 & 51 & 66 & 66 & 66 & 67 & 66 & 67 & 67 & 67 & 67 & 63 & 63 \\
\hline $1980-2007$ & 67 & 67 & 45 & 66 & 67 & 66 & 67 & 66 & 67 & 67 & 67 & 67 & 63 & 63 \\
\hline \multicolumn{15}{|c|}{34 High-Growth Non-OECD Developing Countries } \\
\hline 1970-2007 & 34 & 34 & 25 & 34 & 34 & 34 & 34 & 34 & 34 & 34 & 34 & 34 & 29 & 29 \\
\hline $1970-1979$ & 20 & 16 & 0 & 18 & 16 & 18 & 16 & 18 & 21 & 17 & 16 & 16 & 9 & 9 \\
\hline 1980-1989 & 22 & 24 & 2 & 24 & 24 & 24 & 24 & 24 & 24 & 24 & 24 & 24 & 19 & 19 \\
\hline 1990-1999 & 34 & 34 & 15 & 34 & 34 & 34 & 34 & 34 & 34 & 34 & 34 & 34 & 29 & 29 \\
\hline $2000-2007$ & 34 & 34 & 25 & 34 & 33 & 34 & 34 & 34 & 34 & 34 & 34 & 34 & 29 & 29 \\
\hline 1990-2007 & 34 & 34 & 25 & 34 & 34 & 34 & 34 & 34 & 34 & 34 & 34 & 34 & 29 & 29 \\
\hline $1980-2007$ & 34 & 34 & 25 & 34 & 34 & 34 & 34 & 34 & 34 & 34 & 34 & 34 & 29 & 29 \\
\hline \multicolumn{15}{|c|}{22 Advanced OECD Countries (excluding Luxembourg) } \\
\hline 1970-2007 & 22 & 22 & 22 & 22 & 22 & 22 & 22 & 22 & 22 & 22 & 22 & 22 & 0 & 0 \\
\hline 1970-1979 & 20 & 20 & 3 & 21 & 20 & 21 & 20 & 21 & 21 & 20 & 20 & 20 & 0 & 0 \\
\hline $1980-1989$ & 21 & 21 & 16 & 22 & 21 & 22 & 21 & 22 & 22 & 21 & 21 & 21 & 0 & 0 \\
\hline 1990-1999 & 21 & 21 & 21 & 22 & 21 & 22 & 21 & 22 & 22 & 21 & 21 & 21 & 0 & 0 \\
\hline $2000-2007$ & 22 & 22 & 22 & 22 & 22 & 22 & 22 & 22 & 22 & 22 & 22 & 22 & 0 & 0 \\
\hline $1990-2007$ & 22 & 22 & 22 & 22 & 22 & 22 & 22 & 22 & 22 & 22 & 22 & 22 & 0 & 0 \\
\hline $1980-2007$ & 22 & 22 & 22 & 22 & 22 & 22 & 22 & 22 & 22 & 22 & 22 & 22 & 0 & 0 \\
\hline
\end{tabular}

Notes: The table presents country coverage of average growth and measures of capital flows by sub-periods and country groups from Table 1 . 


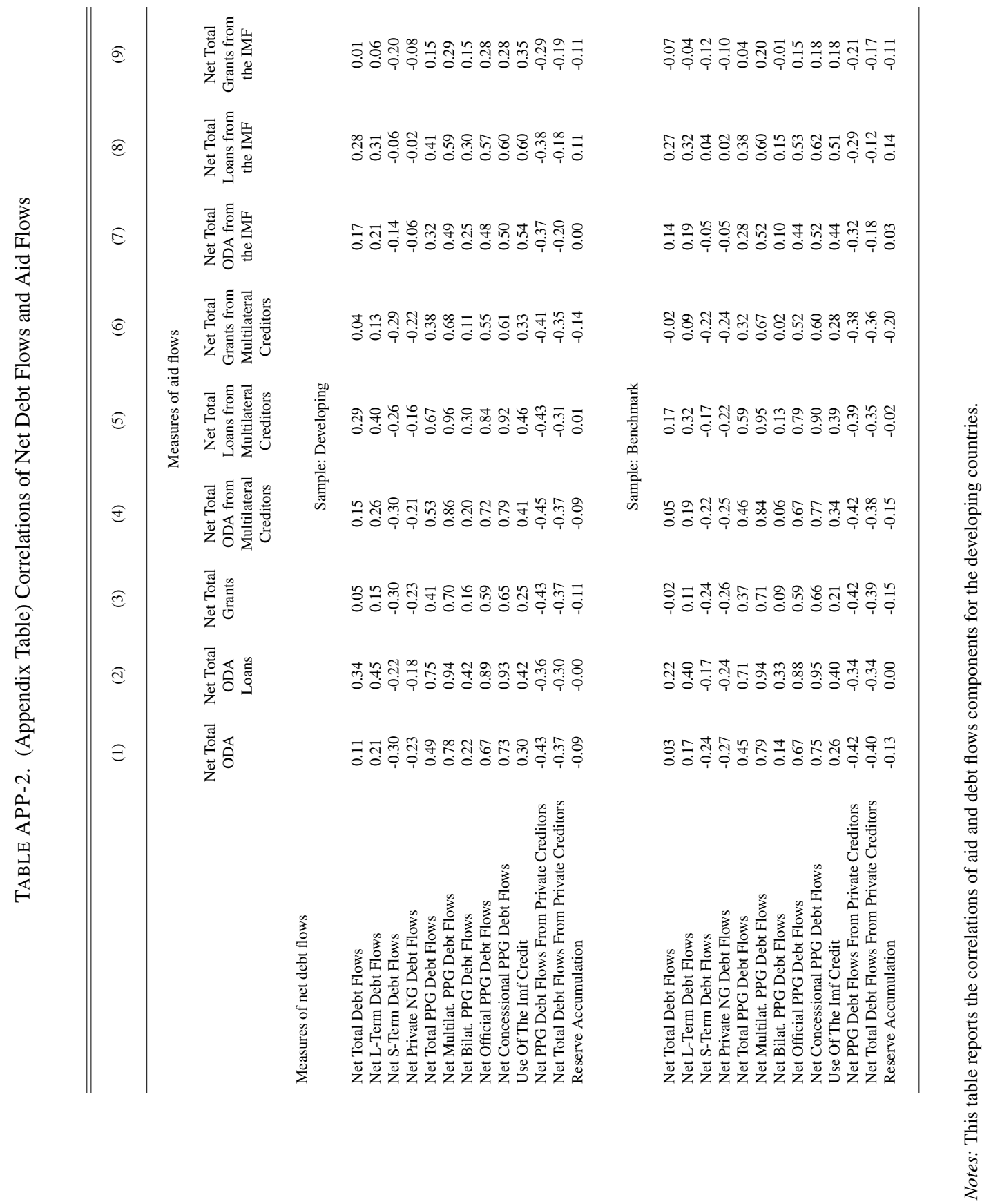


TABLE APP-3. (Appendix Table) Aid Flows and Growth: Decomposition, 1980-2007

Country Sample: Benchmark

\begin{tabular}{lcccc}
\hline \hline & $(1)$ & $(2)$ & $(3)$ & $(4)$ \\
\hline $\begin{array}{l}\text { Dependent } \\
\text { Variable/GDP }\end{array}$ & $\begin{array}{c}\text { Net Total } \\
\text { ODA } \\
\text { (Net Total } \\
\text { Aid Receipts) }\end{array}$ & $\begin{array}{c}\text { Net Total } \\
\text { Grants }\end{array}$ & $\begin{array}{c}\text { Net Total } \\
\text { Grants from } \\
\text { multilat. }\end{array}$ & $\begin{array}{c}\text { Net Total } \\
\text { Grants from } \\
\text { the IMF }\end{array}$ \\
$\begin{array}{l}\text { Average per capita } \\
\text { GDP growth }\end{array}$ & $\begin{array}{c}-0.821^{* *} \\
(0.376)\end{array}$ & $\begin{array}{c}-0.778^{* *} \\
(0.319)\end{array}$ & $\begin{array}{c}-0.276^{* * *} \\
(0.104)\end{array}$ & $\begin{array}{c}-0.009^{*} \\
(0.005)\end{array}$ \\
Obs. & 98 & 98 & 98 & 98 \\
\hline
\end{tabular}

Notes: Robust standard errors are in parentheses. $* * *, * *$, and $*$ denote significance at $1 \%, 5 \%$, and $10 \%$ levels. In this table, all dependent variables are the aid flows computed as the average over 1980-2007 of the annual aid receipts in current U.S. dollars, normalized by nominal GDP in U.S. dollars, and multiplied by 100 . As the aid flow measures, "Net Total ODA" represents all official development assistance (ODA) flows (loans plus grants), defined as those flows to developing countries and Multiple institutions provided by official agencies, including state and local governments, or by their executive agencies. "Net Total Grants" represent Total ODA minus Total ODA loans; ODA loans are loans with maturities of over one year and meeting the criteria set under Official Development Assistance and Official Aid. "Net Total Grants from multilat." represents net ODA grants from Multiple agencies; "Net Total Grants from the IMF" are net ODA grants from the IMF. Average per capita GDP Growth is calculated as the average over 1980-2007 of the annual change of GDP per capita in 2000 U.S. dollars. Details of the variable calculations are in Appendix A, samples are defined in Table 3 and Appendix B, and the countries included are listed in Table $2 .$. 
Leverage against the Squared Normalized Residuals from the Regression of Net capital Flows on Growth in Raw Developing Sample, 1980-2007

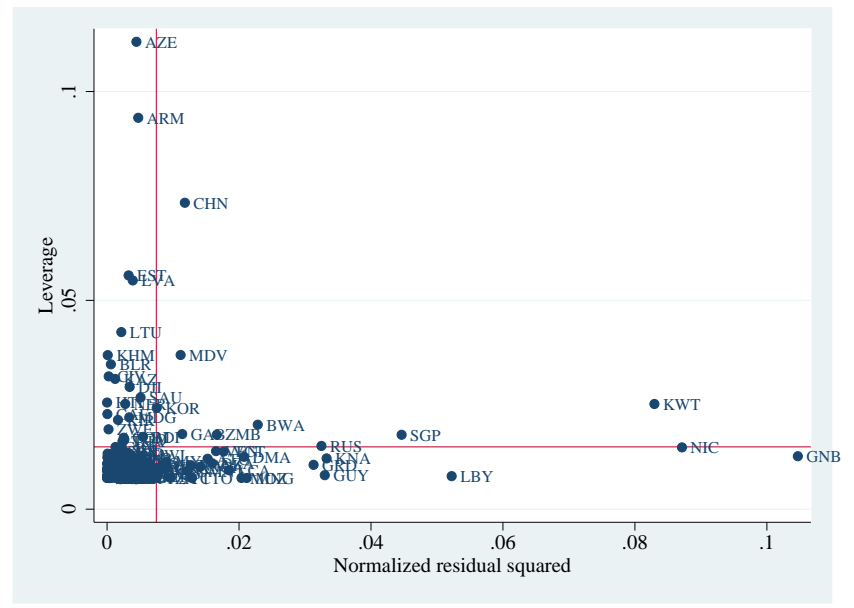

The figure presents the plot of the leverage versus the Studentized residuals from the regression of net capital flows on growth in Raw Developing sample, 1980-2007, as in col(2), Panel A in Table 4. We select our samples by removing the influential observations using DFITS statistics and Cook's D statistics which summarize the information in the leverage and the size of residuals into one statistic.

DFBETA from the Regression of Net capital Flows on Growth in Raw Developing Sample, 1980-2007

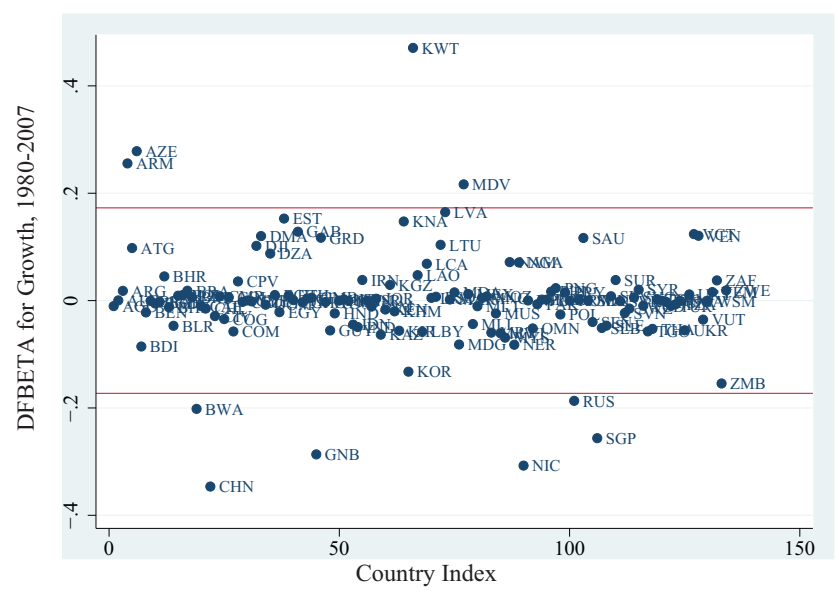

The figure presents the plot of the measure of influence DFBETA from the regression of net capital flows on growth in Raw Developing sample, 1980-2007, as in col(2), Panel A in Table 4. DFBETA demonstrates how the regression coefficient of Growth changes (increases or decreases) by deleting one observation (country) at a time. We eliminate the countries which fall outside of the critical bands for DFBETA in this sample, indicated by the solid horizontal lines.

FIGURE APP-1. Outliers in Terms of Net Capital Flows and Growth in Raw Developing Sample, 1980-2007 


\section{Appendix C: Reconciling with literature, Replication Using Published GJ Codes and Data}

In this appendix we replicate the main regression result (Table 2) of the published version of Pierre-Olivier Gourinchas and Olivier Jeanne "Capital Flows to Developing Countries: The Allocation Puzzle," Review of Economic Studies (2013), doi: 10.1093/restud/rdt004 using the data and codes of these authors (code GJ_results.do) distributed online at http://restud.oxfordjournals.org/content/early/2013/02/14/restud. rdt004/suppl/DC1 (accessed on 16 July 2013) and implements some minor permutation in the sample and the estimation.

In Table APP-4 we use the OLS standard errors and largest GJ sample and in columns (1), (3)-(5) obtain the exact match with Table 2 in Gourinchas and Jeanne (2013). In column (2) we add a regression without Taiwan, as in the rest of this table. The coefficient in column (2) remains negative but the significance of the estimate drops.

In Table APP-5 we repeat the estimation using robust, rather than OLS, standard errors. The coefficient point estimates are, naturally, the same but the the coefficients of the Productivity Catch-up are insignificant or only marginally significant ( $\mathrm{p}$-value of $7 \%$ ) at the conventional levels. 
TABLE APP-4. Exact Replication of Table 2 in the Final Version of GJ

Dependent Variable: Total Capital Flows/GDP 0

\begin{tabular}{|c|c|c|c|c|}
\hline & (1) & (2) & (3) & (4) \\
\hline & & $\begin{array}{c}\text { Col (1) ex. } \\
\text { Taiwan }\end{array}$ & & \\
\hline Productivity Catch-up & $-0.586 * * *$ & $-0.469 * *$ & $-0.456 * *$ & $-0.697 * * *$ \\
\hline Relative to the U.S. $(\pi)$ & $(0.217)$ & $(0.215)$ & $(0.209)$ & $(0.227)$ \\
\hline Initial Capital Abundance $\left(k_{0} / y_{0}\right)$ & $\begin{array}{l}-0.161 \\
(0.115)\end{array}$ & $\begin{array}{l}-0.164 \\
(0.111)\end{array}$ & $\begin{array}{l}-0.126 \\
(0.109)\end{array}$ & $\begin{array}{c}-0.0809 \\
(0.107)\end{array}$ \\
\hline Initial Debt $\left(d_{0} / y_{0}\right)$ & $\begin{array}{c}0.00583 \\
(0.003)\end{array}$ & $\begin{array}{c}0.00444 \\
(0.003)\end{array}$ & $\begin{array}{c}0.00416 \\
(0.003)\end{array}$ & $\begin{array}{c}0.00131 \\
(0.003)\end{array}$ \\
\hline Population Growth $(n)$ & $\begin{array}{c}-0.0583 \\
(0.104)\end{array}$ & $\begin{array}{c}-0.0765 \\
(0.101)\end{array}$ & $\begin{array}{c}-0.0980 \\
(0.099)\end{array}$ & $\begin{array}{c}-0.0733 \\
(0.096)\end{array}$ \\
\hline Average KA Openness (Chinn-Ito) & & & $\begin{array}{c}-0.141^{* *} \\
(0.063)\end{array}$ & $\begin{array}{c}-0.115^{*} \\
(0.062)\end{array}$ \\
\hline Average KA Openness $\times \pi$ & & & & $\begin{array}{c}-0.455^{* *} \\
(0.197)\end{array}$ \\
\hline Intercept & $\begin{array}{c}0.516 \\
(0.315)\end{array}$ & $\begin{array}{c}0.627 * * \\
(0.308)\end{array}$ & $\begin{array}{l}0.576^{*} \\
(0.299)\end{array}$ & $\begin{array}{l}0.536^{*} \\
(0.289)\end{array}$ \\
\hline Obs. & 68 & 67 & 67 & 67 \\
\hline Adj. $R^{2}$ & 0.174 & 0.104 & 0.157 & 0.214 \\
\hline
\end{tabular}

Notes: OLS standard errors are in parentheses. $* * *, * *, *$ denote significance at $1 \%, 5 \%, 10 \%$ levels. The results are estimated using the data and codes of Gourinchas and Jeanne (2013) distributed online at http://restud.oxfordjournals.org/content/early/2013/02/14/restud.rdt004/supp1/DC1. 
TABLE APP-5. Replication of Table 2 in the Final Version of GJ with Robust Standard Erors Dependent Variable: Total Capital Flows/GDP 0

\begin{tabular}{|c|c|c|c|c|}
\hline & (1) & (2) & (3) & (4) \\
\hline $\begin{array}{l}\text { Productivity Catch-up } \\
\text { Relative to the U.S. }(\pi)\end{array}$ & $\begin{array}{c}-0.586^{*} \\
(0.337)\end{array}$ & $\begin{array}{l}-0.469 \\
(0.342)\end{array}$ & $\begin{array}{l}-0.456 \\
(0.330)\end{array}$ & $\begin{array}{c}-0.697 * \\
(0.377)\end{array}$ \\
\hline Initial Capital Abundance $\left(k_{0} / y_{0}\right)$ & $\begin{array}{l}-0.161 \\
(0.156)\end{array}$ & $\begin{array}{l}-0.164 \\
(0.158)\end{array}$ & $\begin{array}{l}-0.126 \\
(0.133)\end{array}$ & $\begin{array}{l}-0.0809 \\
(0.122)\end{array}$ \\
\hline Initial Debt $\left(d_{0} / y_{0}\right)$ & $\begin{array}{c}0.00583 \\
(0.004)\end{array}$ & $\begin{array}{c}0.00444 \\
(0.004)\end{array}$ & $\begin{array}{c}0.00416 \\
(0.003)\end{array}$ & $\begin{array}{l}0.00131 \\
(0.004)\end{array}$ \\
\hline Population Growth $(n)$ & $\begin{array}{c}-0.0583 \\
(0.131)\end{array}$ & $\begin{array}{c}-0.0765 \\
(0.131)\end{array}$ & $\begin{array}{c}-0.0980 \\
(0.133)\end{array}$ & $\begin{array}{l}-0.0733 \\
(0.114)\end{array}$ \\
\hline Average KA Openness (Chinn-Ito) & & & $\begin{array}{c}-0.141^{*} \\
(0.078)\end{array}$ & $\begin{array}{l}-0.115^{*} \\
(0.062)\end{array}$ \\
\hline Average KA Openness $\times \pi$ & & & & $\begin{array}{c}-0.455^{*} \\
(0.235)\end{array}$ \\
\hline Intercept & $\begin{array}{c}0.516 \\
(0.345)\end{array}$ & $\begin{array}{l}0.627 * \\
(0.338)\end{array}$ & $\begin{array}{l}0.576^{*} \\
(0.289)\end{array}$ & $\begin{array}{l}0.536 * * \\
(0.243)\end{array}$ \\
\hline $\begin{array}{l}\text { Obs. } \\
\text { Adj. } R^{2}\end{array}$ & $\begin{array}{c}68 \\
0.174\end{array}$ & $\begin{array}{c}67 \\
0.104\end{array}$ & $\begin{array}{c}67 \\
0.157\end{array}$ & $\begin{array}{c}67 \\
0.214\end{array}$ \\
\hline
\end{tabular}

Notes: Robust standard errors are in parentheses. $* * *, * *, *$ denote significance at $1 \%, 5 \%, 10 \%$ levels. The results are estimated using the data and codes of Gourinchas and Jeanne (2013) distributed online at http://restud.oxfordjournals.org/content/early/2013/02/14/restud.rdt004/suppl/DC1. 